\author{
UNIVERSIDADE DE SÃO PAULO \\ FACULDADE DE FILOSOFIA, LETRAS E CIÊNCIAS HUMANAS \\ DEPARTAMENTO DE LETRAS MODERNAS \\ PROGRAMA DE PÓS-GRADUAÇÃO EM LÍNGUA E LITERATURA FRANCESA
}

\title{
ESCRITURA DA PERDA: \\ UM TEMPO NÃO-RECONCILIADO EM BANDEIRA E APOLLINAIRE
}

Tatiane Milene Torres

Dissertação apresentada ao Programa de PósGraduação em Língua e Literatura Francesa, do Departamento de Letras Modernas da Faculdade de Filosofia, Letras e Ciências Humanas da Universidade de São Paulo, para obtenção do título de Mestre em Letras.

Orientador: Prof(a) Dr(a) Maria Cecília de Moraes Pinto 
UNIVERSIDADE DE SÃO PAULO

FACULDADE DE FILOSOFIA, LETRAS E CIÊNCIAS HUMANAS

DEPARTAMENTO DE LETRAS MODERNAS

PROGRAMA DE PÓS-GRADUAÇÃO EM LÍNGUA E LITERATURA FRANCESA

\section{ESCRITURA DA PERDA:}

UM TEMPO NÃO-RECONCILIADO EM BANDEIRA E APOLLINAIRE

Tatiane Milene Torres

São Paulo

2007 
Aos queridos

NEUSA, ISAÍAS E CLÉCIO

amores genuínos 


\section{Agradeço}

À Profa. Dra. Maria Cecília, pelo apoio e compreensão que me dedicou e pela desmedida experiência transposta para orientações que me levaram, quando enleada, a voltar à vereda poética.

À Profa. Dra. Maria Lídia, que me despertou para a paixão literária e pela imensurável atenção que me dedicou na graduação.

À Profa. Dra. Sandra Nitrini, pela solicitude de sempre, mesmo em meio a tantos afazeres.

À Profa. Dra. Maria Augusta, pelos notáveis pareceres.

À Secretaria da Educação, pela concessão da bolsa.

Aos meus pais, pelos aplausos de sempre, independentemente do sucesso.

Ao Clécio, querido irmão, alicerce de todas as construções.

Ao Joceley, pela colaboração em vários momentos na execução deste projeto.

À Iara e Nevinha, pelas lições de fé e de força, amigas queridas.

Aos queridos amigos, que de perto ou de longe, ensinaram-me a amar malgrado a distância.

A Deus, que me fortaleceu para enfrentar as intempéries. 


\title{
SUMÁRIO
}

\author{
Resumo 06 \\ Résumé 07 \\ Abstract 08 \\ Introdução 09
}

\section{Capítulo I}

Rumo a Pasárgada e aos Caligrammes 15

\section{Capítulo II}

Ainda que haja uma influência confessa 29

\section{Capítulo III}

0 diálogo entre a poética bandeiriana e apollinairiana $\quad 56$

$3.1 \mathrm{O}$ medievalismo na lírica dos poetas 56

3.2 O noturno como marca de uma poesia penumbrista 77

3.3 A efemeridade do amor e a inexorabilidade do tempo 88

3.4 A Epifania e o Ubi Sunt? 123

3.5 O gozo a partir da contemplação 131

3.6 Ainda que o júbilo desponte em meio à melancolia 139

3.7 O destino talhado pela má-sina 151

\section{Considerações Finais 161}

\section{Referências Bibliográficas 162}




\section{RESUMO}

Tendo em vista a influência confessa da poética apollinairiana nas primeiras produções de Manuel Bandeira, o que não se deve a uma leitura positivista segundo a escola francesa tradicional, propomos a análise temático-comparativa de poemas retirados da obra A cinza das horas (1917) e de Alcools (1913). O estudo se dá a partir da recorrência motívica central do tempo, presente em ambos os poetas, que traduzem os seus desgostos íntimos através de uma linguagem sentimentalmente artística e expressiva em que o amor canta a morte. A dor, o tédio, a solidão e a melancolia são os sentimentos que sustentam essa condição poética desditosa, buscando resgatar aquilo que findou por meio de um tempo mítico, haja vista que este será eternamente nãoreconciliado, estando o olhar poético direcionado para um passado que traz reminiscências dolorosas. Além disso, nossa preocupação é a de observar como esse tema é representado em seus vários subtemas, bem como nas diferentes formas poéticas que constituem nosso corpus de análise.

Palavras-Chaves: Tempo, Infortúnio, Amor, Bandeira, Apollinaire. 


\section{RÉSUMÉ}

À propos de l'influence avoue de la poétique apollinairiènne dans les premières productions de Manuel Bandeira, ce qui ne suit pas une lecture positiviste selon l'école française traditionelle, nous proposons l'analyse thématique-comparative de poèmes retirés de l'oeuvre A cinza das horas (1917) et d'Alcools (1913). L'étudie se dévellope à partir de la thématique central du temps reprise dans les oeuvres, présente dans les poètes, qui traduisent leurs dégoûts intimes au moyen d'une langage sentimentalement artistique et expressive dans laquelle l'amour chante la mort. La douleur, la solitude et la mélancolie sont sentiments qui soutiennent cette poétique de l'infortune, laquelle cherche récupérer à travers le temps mythique ce qui a fini, vu que celui-ci sera éternellement non-réconcilié, étant le regard poétique orienté pour le passé qui apporte des tristes reminiscences. En outre, notre préoccupation est observer de quelle manière cette thématique est représentée dans ses plusieurs subthèmes, aussi dans les différentes formes poétique qui constituent notre corpus d'analyse.

Mots-Clés: Temps, Infortune, Amour, Bandeira, Apollinaire. 


\begin{abstract}
As we have the known influence of the Apollinaire poetry at the first production of Manuel Bandeira, which is based on the reading of the positivism according to the traditional french school, the main aim of this research is to analyse tematic and comparatively the poems taken from the works A cinza das horas (1917) and Alcools. The cited research has been developed through the central constant motive of the time, being held at both poets' works, which translate their inner disgustings throughout the sentimental-artistic and the expressive language, where the love sings the death. The pain, the tedium, the lonely and the melancholia are the feelings that supply such unfortunate poetic condition, trying this way to recollect what is over through a mythical time, remembering that such time will never be recuperated, through a poetic sight focused on the past which brings painful remains. Nevertheless, our main concern is to observe how such theme is represented in its assorted subthemes, as well as how the different poetic forms are built in our analysis.
\end{abstract}

Keywords: Time, Bad Luck, Love, Bandeira, Apollinaire. 
INTRODUÇÃO 


\section{Introdução}

Em estudos realizados durante a graduação como bolsista do programa FAPESP, demos início ao estudo dos poetas Manuel Bandeira e Guillaume Apollinaire, com suas respectivas obras A Cinza das Horas e Alcools. O surgimento da idéia do trabalho se deu no momento em que estudávamos poesia brasileira e percebemos que essa tinha muitas relações com a poesia francesa. Foi então que, lendo alguns poetas franceses e brasileiros, observamos certas similitudes entre Bandeira e Apollinaire, que nos despertaram grande interesse, sobretudo no que concerne à fase inicial de suas obras, ainda com traços notadamente melancólicos de uma poesia finissecular e parnasianosimbolista.

É importante salientar que o desenvolvimento de tal projeto trouxe um enriquecimento assaz relevante no que diz respeito a nossa formação enquanto docente e, por conseguinte, pesquisadora. Assim, pudemos ter acesso a todo um universo acadêmico que nos era desconhecido, ao participarmos de vários congressos e ao desenvolvermos a pesquisa, com os relatórios semestrais e finais entregues à FAPESP. Outro fator significativo foi a aceitação do pedido de prorrogação da bolsa pelo programa, o que garantiu um maior tempo para trabalhar na pesquisa e uma maior participação em congressos.

Mesmo com a ampliação do prazo e com a aprovação final do relatório, percebemos que o estudo necessitava de uma maior fundamentação teórica e metodológica. Então, observamos que o corpus pedia ampliação, posto que alguns poemas essenciais não tinham feito parte da análise inicial e que um outro viés literário surgiu como resultado do desenvolvimento da pesquisa. Por conta disso, trouxemos o projeto da graduação para o mestrado, sendo possível o aumento do corpus em mais onze poemas.

Acreditamos que a execução desse projeto poderá levar a um maior conhecimento e aprofundamento literário de dois grandes poetas modernos, ambos com características parnasiano-simbolistas em suas obras iniciais, que já apresentavam traços 
importantíssimos para o desenvolvimento do Modernismo Brasileiro e das Vanguardas Francesas. O tema a ser abordado nas análises dos poemas de Manuel Bandeira e de Guillaume Apollinaire circunda a elegia amorosa, como sentimento principal, mas ele representa toda uma atmosfera melancólica de um eu lírico marcado por um "mau destino" cujas perdas são irreparáveis, resultado de um tempo não-reconciliado, segundo a teoria de Gilles Deleuze do círculo eternamente descentrado, o da Diferença ${ }^{1}$

O tema a ser estudado "Escritura da perda: um tempo não-reconciliado em Bandeira e Apollinaire", leva-nos necessariamente à consideração do tom melancólicocrepuscular típico da poesia finissecular:

o lirismo elegíaco de Bandeira [e diríamos de Apollinaire] caracteriza suas dores pessoais que se misturam com a sentimentalidade crepuscular da poesia do fim do século XIX, criando um clima de melancolia. (GARBUGLIO, 1998, p.59)

A elegia $^{2}$ é aqui concebida como um pequeno poema consagrado ao luto ou à tristeza pela perda do objeto do amor, exprimindo sempre um lamento doloroso e sentimentos melancólicos. A noite vai funcionar como cenário de eleição nessa representação do mundo em que o amor e a ausência do objeto amado se conjugam nostalgicamente (Cf. ROSENBAUM, 1993, p. 51). Podemos dizer que essas faltas ou perdas estão relacionadas aos amores frustrados do eu lírico bandeiriano e apollinairiano, de maneira a ser possível identificar em suas obras um grande amor que se esvaeceu: o de Marie, que inspirou em Apollinaire, após rompimento definitivo, um belíssimo poema de mesmo nome, e o de Maria Cândida, irmã de Bandeira que, inspirado em uma de suas cartas, escreve "A Canção de Maria”. Devemos destacar que essas perdas ou faltas não estão somente ligadas aos amores frustrados e perdidos do passado, mas também à passagem do tempo, ao saudosismo do eu poético, sobretudo

\footnotetext{
${ }^{1}$ Teoria de Gilles Deleuze, com a qual justificamos a figura do mal-amado, inserida no livro Différence et Répétition (1968) que aborda a questão de um terceiro tempo, tomado como o da Diferença: "Ce que ce livre aurait dû randre présent, c'est donc l'approche d'une cohérence qui n'est pas plus la nôtre, celle de l'homme que celle de Dieu ou du monde. En ce sens, ç'aurait dû être un livre apocalyptique (le troisième temps dans la série du temps)" (p.4).

${ }^{2}$ Para compreendermos o lirismo elegíaco observado nas obras, é mister destacar o significado do termo elegia: "S. F. 1. Entre os gregos e latinos, poema formado de versos hexámetros e pentâmetros alternados. 2. Poema lírico, cujo tom é quase sempre terno e triste" (Aurélio, 1995,
} 
em relação às coisas mais simples do cotidiano, que foram vivenciadas e que ficaram para trás: "Nessa passagem do tempo, o calor aquece o passado e deixa o presente entregue à frustração do poeta" (ROSENBAUM, 1993, p. 51). Logo, o amor elegíaco provém de um sujeito inconformado com a sua própria trajetória de vida marcada por diferentes tipos de amor, que permanecem em suas lembranças angustiantes.

A partir dessa perspectiva de leitura dos poemas, concebidos sempre como elegíaco-amorosos, ou seja, de um lirismo quase sempre terno e triste dada a situação de luto em que o eu lírico se encontra (perda do ente amado ou de um tempo nãoreconciliado), analisamos o modo como se dá a representação poética nos dois autores mencionados. Acrescente-se que eles não foram, até o momento, aproximados sob o viés nostálgico e doloroso de se fazer poesia, sobretudo concentrado na sua fase inicial com fortes marcas de um lirismo triste, característico do fim do século XIX e início do século XX, e que remonta até mesmo à Idade Média e a antiguidade.

Nesse sentido, com a finalidade de avaliar os recursos poéticos utilizados por Bandeira e Apollinaire, apontando suas semelhanças e diferenças, o trabalho deteve-se, primeiramente, na leitura e levantamento de textos crítico-analíticos sobre A Cinza das Horas e Alcools, privilegiando os seguintes poemas da lírica bandeiriana: "Solau do Desamado", "Crepúsculo de Outono", "A Canção de Maria”, "O Anel de Vidro", "Dentro da Noite", "Confissão", "Enquanto morrem as rosas", "Madrugada", "Ao Crepúsculo", "Volta", "Oceano", e da lírica apollinairiana: "Le Pont Mirabeau”, "La Chanson du Mal Aimé", "Marie”, “Automne Malade”, "Nuit Rhénane”, “1909”, "Mai”, "Le Vent Nocturne", "Crépuscule", "Rosemonde" e "Signe".Tais leituras e levantamento objetivam, extrair dos textos o já estudado pelos críticos, de modo a estabelecer um ponto de partida para que este trabalho de análise tenha um mínimo de originalidade e uma fundamentação teórico-analítica o mais consistente possível.

O critério de seleção dos poemas é o de eles conterem a manifestação, por parte dos poetas, de uma submissão à força do mau destino, ao tédio baudelairiano: "o mau destino queima sem razão nem dó o coração do[s] poeta[s], reduzindo-o[s] a um montinho de cinza fria" (COELHO, 1982, p. 17).

Após a leitura das obras que serviram de base para as análises e reflexões críticas de Alcools e de A Cinza das Horas, classificamos os poemas acima mencionados pelos

p. 236). De tal definição, trabalhamos com a segunda que explicita o caráter pesaroso dos poemas analisados. 
seguintes subtemas que, de alguma forma, justificam a figura do eu-lírico mal-amado: "O Medievalismo na lírica bandeiriana e apollinairiana", "O noturno como marca de uma poesia penumbrista", "A efemeridade do amor e a inexorabilidade do tempo", A vida como misto de angústia e esperança", "A epifania e o Ubi Sunt?”, "O gozo a partir da contemplação" e "O destino talhado pela má-sina". Os poemas são analisados, em um primeiro momento, separadamente, para uma melhor compreensão, sobretudo no que concerne as suas diferenças, além de direcionar de forma inteligível e didática a sua leitura.

Em um segundo momento fazemos o diálogo propriamente dito entre os poemas, aos pares, enfatizando a questão temática desenvolvida, e considerando alguns aspectos formais na medida em que são pertinentes para o enriquecimento da pesquisa. 
CAPÍTULO I 


\section{Rumo a Pasárgada e aos Calligrammes}

O presente capítulo resulta de uma síntese de conjeturas acerca da poesia de Manuel Bandeira e de Apollinaire, tanto em sua fase inicial, com traços notadamente líricos no alvorecer do século XX, quanto em sua fase já avançada em termos de modernidade poética. Para uma melhor compreensão da lírica bandeiriana e apollinairiana, fizemos um levantamento de dados biográficos relevantes, de modo que auxiliem o esclarecimento de aspectos nebulosos da poética dos autores.

A propósito dos autores, Guillaume Apollinaire Albert Kostrowitzky, nasce em Roma, no dia 26 de agosto de 1880. Sua origem paterna é desconhecida, sabe-se apenas que sua mãe, de origem polonesa e italiana, teve uma efêmera relação com Francesco Flugi d'Aspermont, um italiano que se presume ser seu pai. Após seis anos, nasce Manuel Carneiro de Souza Bandeira Filho em Recife, no dia 19 de abril, na Rua da Ventura, atual Joaquim Nabuco. É interessante notar que ambos autores, em sua infância, fizeram várias viagens. Apollinaire com sua mãe Angélica e seu irmão Albert saem de Roma em 1887 e se instalam em Mônaco, após esse período, entre 1896-1897, passa por Cannes e depois por Nice. Em 1899, a família se instala finalmente em Paris, em condições precárias. Bandeira também viaja na infância : sua família, em 1890, se transfere de Recife para o Rio e, a seguir, para São Paulo e, novamente, Rio de Janeiro, passando dois verões em Petrópolis. Em 1892, retorna para Pernambuco e mais uma vez para o Rio de Janeiro, em 1896. Vale destacar que é na ou sobre a infância dos poetas que eclodem muitos poemas: Bandeira que busca recuperar o período realmente feliz de sua vida, antes da doença e com os seus queridos, em "Evocação do Recife", e Apollinaire, ao relembrar a Roma onde nasceu, sua origem misteriosa com todas as suas intempéries, no verso 95 de "Vendémiaire", reduzido a duas sílabas "Ô Rome", sendo mais explícito no manuscrito: "Ô Rome, Ô Rome où je suis né” ou em "Zone”: 
Et moi en qui se mêle le sang slave et le sang latin

Je regarde ces pauvres Polonais [...]

("Zone")

Lorsque la nuit revint couverte d'yeux ouverts

Errer au site où l'hydre a sifflé cet hiver

Ô Rome

Maudire d'un seul coup mes anciennes pensées

Et le ciel où l'amour guide les destinées

("Vendémiaire")

Nunca pensei que ela acabasse!

Tudo lá parecia impregnado de eternidade

(“Evocação do Recife")

É importante mencionar que, nesse período, os dois poetas estudaram. Bandeira em 1892 no colégio das irmãs Barros Barreto, como semi-interno do Virgínio Marques Carneiro Leão, e, ainda em 1896, no Externato do Ginásio Nacional. Apollinaire no colégio Saint-Charles de Mônaco entre 1887-1895, no Stanislas de Cannes e no Liceu de Nice, entre 1896-1897. Mas não chega a se formar e abandona os bancos escolares no verão de 1897 , final de 1898 , embora fosse um excelente aluno e se interessasse sobremaneira pelos estudos: "Guillaume est un bon élève. À onze ans (1891), en septième, il obtient sept prix et cinq accessits, dont le second prix d'excellence et le premier prix de français et de calcul" (PARINAUD, 1994, p.21). O abandono dos estudos não impede que Apollinaire se torne um leitor ainda mais voraz, e passe os dias a ler e a escrever, posto que objetiva ser escritor ou jornalista. O curioso é que, após seis anos, quem tem os estudos interrompidos é Bandeira, que abandona o sonho de ser arquiteto ao descobrir que está tuberculoso.

Apollinaire, ao abandonar os estudos, precisa trabalhar para se manter, pois a situação financeira da família é extremamente difícil. Então, em 1900, começa a 
desenvolver diversos tipos de ocupação, visto que, sendo estrangeiro e sem formação, não pode exigir e escolher qualquer ofício. Em maio de 1901, torna-se professor de francês da filha de Gabrielle Milhau, viúva de um conde, proveniente de uma rica família de Cologne.

É nesse momento que inicia suas atividades literárias com mais afinco, tendo publicado três poemas na revista La Grande France de setembro. Como sua situação financeira é crítica, ao receber a proposta irrecusável de Mme Milhau para acompanhála à Alemanha, sem hesitar a aceita. No ambiente germânico cada elemento do cotidiano será para Apollinaire uma inesgotável fonte de inspiração, como por exemplo a coletânea "Rhénanes", além de nessa época apaixonar-se por Annie, uma jovem inglesa que trabalhava também para Mme Milhau. Nesse ínterim, Bandeira cursa o ginásio em Pernambuco e muda para São Paulo, em 1903, a fim de matricular-se na Escola Politécnica, onde pretende tornar-se arquiteto. Mas seu sonho é interrompido em 1904, quando descobre a tísica que será fiel companheira ao longo de toda a sua vida, e volta para o Rio de Janeiro. Em busca de um clima melhor para sua saúde começa a viajar, passando várias temporadas em diversas cidades: Campanha, Teresópolis, Maranguape, Uruquê, Quixeramobim.

Nesse mesmo ano, Apollinnaire freqüenta os meios intelectuais da época, como o ateliê de Picasso, onde tem oportunidade de conhecer vários eruditos, dentre os quais o escritor Max Jacob.Também conhece os pintores Derain e Vlamink, em seus passeios dominicais ao lado do Chatou, contatos que serão decisivos para sua poética.

Faz sua segunda viagem à Inglaterra para tentar em vão recuperar o amor de Annie, mas o rompimento é definitivo. De 1907 a 1911, o poeta se instala em Montmartre em seu primeiro domicílio próprio e conhece Marie Laurencin, uma pintora com a qual terá um relacionamento conturbado até meados de 1912. Nesse período, colabora em vários periódicos, tem uma intensa atividade literária e jornalística. Em 1909, instala-se em Auteuil, ficando assim próximo ao domicílio de sua amada, Marie. Outro acontecimento importante na vida do poeta é a sua prisão em Santé por seis dias, em 1911, quando é acusado injustamente de ter roubado a Joconda do Louvre, fato que lhe causa bastante angústia e inspira o poema "À la Santé".

Em 1910, Manuel Bandeira participa de um concurso de poesia da Academia Brasileira de Letras e vence, mas não recebe o prêmio de 500mil réis, como determinado. Em 1912, o poeta escreve seus primeiros versos livres, sob influência de 
Apollinaire, Charles Cros, Mac-Fionna Leod. Nesse mesmo ano, Apollinaire funda a revista Les Soirées de Paris, com André Billy, André Salmon, André Tudesq e René Dalize. Mais um ano de intensa atividade literária, com uma nova série de contos no Paris-Journal, "Merlin et la vieille femme" no Les Rubriques nouvelles, e tantos outros poemas que se sucedem.Mais uma ruptura amorosa na vida do poeta. Após uma cena um tanto quanto violenta, Marie o deixa, mantendo um estado que durou dois meses.

Em 1913, Manuel Bandeira, aconselhado a procurar tratamento na Europa, viaja em junho, apesar de sua situação financeira, e vai para o sanatório de Clavadel, na Suíça. Os quinze meses de Clavadel são decisivos para a saúde do poeta, que também conhece Paul Eugène Grindel, que se torna um grande poeta da literatura francesa e reaprende o alemão estudado nos tempos de colégio. No mesmo ano, Apollinaire publica Alcools, com poemas escritos no período de quinze anos e compõe seu primeiro "poème-conversation", "Les fenêtres". Também publica o manifesto L'Antitradition futuriste, torna-se o anunciador do Cubismo e se afasta cada vez mais das antigas formas.

No mesmo período, Bandeira pensa pela primeira vez em publicar um livro, chegando a organizá-lo sob o título de Poemetos Melancólicos. Enviá-o a Eugênio Castro, que está em Coimbra, e do qual não recebe sequer resposta. Ao deixar o sanatório em outubro de 1914, devido ao início da Primeira Guerra Mundial, esquece os originais do livro que jamais conseguirá recuperar na íntegra. Em 1915, Apollinaire parte para a Guerra, embevece-se com a beleza de tal combate, quiçá uma visão poética, e, mesmo em meio a esse cenário caótico, não cessa de escrever seus poemas. É ferido em 1916, no momento em que lhe concedem a nacionalidade francesa, e volta para casa devido a um grave ferimento, sendo homenageado como "poète-héros".

No momento em que Apollinaire volta para casa, Bandeira vivencia uma das primeiras perdas de sua vida, sua mãe, Francelina Ribeiro de Souza Bandeira. No ano seguinte, em 1917, ele reúne poemas que havia escrito nos dez anos anteriores e publica-os sob o título de A cinza das horas, em uma tiragem de 200 exemplares, custeados pelo próprio autor. Apollinaire produz a peça Les Mamelles de Tirésias, fundamentada em características surrealistas, sendo bastante criticada pelo público. Publica, em 1918, seis pequenos poemas intitulados Vitam impedere amori, em homenagem à Marie Laurencin e também sua conferência sobre o Esprit Nouveau. Nesse mesmo ano, sai Calligrammes e no dia 2 de maio casa-se com Jaqueline Kolb, com quem permanecerá pouquíssimo tempo, posto que em novembro adoece vítima da 
gripe espanhola e morre no dia 9, em Paris, aos 38 anos e, até o fim, em plena atividade literária.

Bandeira ainda vive por mais 50 anos após a morte de Guillaume Apollinaire, tendo no mesmo ano da perda do poeta francês, a de sua irmã Maria Cândida de Souza Bandeira, que foi para ele uma enfermeira extremamente afetuosa.

Em 1919, publica Carnaval que, com o primeiro livro, compõe o período prémodernista de Bandeira, com poemas que seguem uma linhagem ainda parnasianosimbolista, mas com inovações, elogiado por João Ribeiro e já com laivos decisivos para os precursores do Modernismo.

Como as mortes são uma constante na vida e na obra do poeta, é importante acrescentar que, antes de seu terceiro livro, presencia mais uma perda, a de seu pai, Manuel Carneiro de Souza Bandeira, em 1920. O poeta nesse momento vê-se sozinho, com a saúde debilitada, em situação financeira crítica e sem condições para trabalhar como outras pessoas. Após a morte do pai, antigo engenheiro do Ministério de Viação e Obras Públicas, recebe uma pensão mensal, na condição de "filho maior inválido". Ao pagar o aluguel, sobra-lhe pouco dinheiro para suas despesas, tendo que complementar o orçamento com trabalhos na imprensa e com traduções. Diante de tal situação, Bandeira, em carta de 1926 a Carlos Drummond de Andrade, revela ao amigo: "Ando numa miséria tão safada que preciso defender os tostões para comer!"

Em 1922, Manuel Bandeira não participa da Semana de Arte Moderna, pois afirma que deve muito aos parnasianos (tradição) para ridicularizá-los fortuitamente, mas tem seu poema "Os Sapos", de Carnaval, declamado no evento por Ronald de Carvalho. Nesse mesmo ano, morre seu irmão, Antônio Ribeiro de Souza Bandeira, apenas dois anos depois da morte de seu pai.

Até 1930, antes da publicação de Libertinagem, custeada ainda pelo próprio autor, participa de muitos eventos e atividades que colaboram para o seu desenvolvimento no viés modernista. Então, Bandeira, com um de seus versos, marca a decisiva adesão ao movimento "Não quero mais saber do lirismo que não é libertação".

Em 1935, Manuel Bandeira é nomeado, pelo Ministro Gustavo Capanema, inspetor de ensino secundário, tendo, aos 49 anos, a primeira atividade fixa remunerada. Após três anos, torna-se professor de literatura geral do Colégio Pedro II, e, em 1943, abandona tal atividade para assumir a cadeira de literatura hispano-americana na Faculdade Nacional de Filosofia. 
No ano de 1936, realizam-se grandes comemorações que marcam os cinqüenta anos do poeta, dentre as quais a publicação de Homenagem a Manuel Bandeira. Nessa obra os participantes chegam a trinta e três, entre os mais importantes escritores brasileiros, com poemas, estudos críticos e comentários. No mesmo ano publica Estrela da manhã.

Mas é somente em 1937 que recebe o primeiro retorno financeiro considerável com sua poesia, um prêmio concedido pela Sociedade Filipe de Oliveira.

Em 1940, é eleito para a Academia Brasileira de Letras, ocupando a vaga que era de Luís Guimarães Filho. Publica Poesias Completas, sendo aí inserida a obra Lira dos Cinqüent'Anos, custeada também pelo autor.

Na seqüência, publica Belo Belo em 1948, Mafuá do Malungo em 1949, Opus 10 em 1952, Estrela da Tarde em 1958 e Estrela da Vida Interia em 1966.

É importante salientar que, nesses anos, Bandeira escreve prosa e crítica literária, não apenas poesia, e traduz muitos textos, como, em 1956, a peça Macbeth, de Shakespeare, em 1961 Mereille, de Fréderic Mistral, entre outros.

Em 1967, um ano antes de sua morte, tendo a saúde se agravado, muda-se para o apartamento de Maria de Lourdes Heitor de Souza, sua companheira dos últimos anos.

Em 1968, aos 82 anos, morre no Hospital Samaritano, em Botafogo, sendo sepultado no mausoléu da Academia Brasileira de Letras, no cemitério São João Batista.

É interessante destacar, após finalizarmos a biografia dos poetas, que ambos participam de uma evolução literária semelhante, obviamente cada um a sua maneira, respeitando as características próprias da literatura de seu país. Eles partem de uma poesia com traços notadamente parnasiano-simbolistas e adentram decisivamente na nova tendência vanguardista, no caso de Apollinaire, e no Modernismo, no caso de Bandeira que, na expressão de Mário de Andrade, foi considerado o São João Batista do movimento.

Isto posto, partimos para a análise das obras aqui estudadas, tanto no que concerne a sua contribuição para o desenvolvimento em termos de modernidade poética, quanto a sua herança característica de um começo de século que denuncia uma certa ‘indefinição’ literária.

Por isso, é importante indagar a respeito da situação da literatura brasileira no momento em que Bandeira publica o livro de 1917. Prevalece um contexto de indefinição, mas com alguns traços que já denunciam um momento de transição, que 
será efetivamente decisivo dentro de alguns anos. Como Américo Facó ${ }^{3}$ observa, o primeiro livro de Bandeira apresenta marcas inspiradas em "escolas", o que significa para a época características de uma poesia elevada e de "bom gosto". O crítico também nota que o poeta estreante apresenta sinais de talento e de erudição, denunciando o domínio das técnicas formais do fazer literário, confirmando a relação com notáveis autores da língua nacional e estrangeira, com a tradição. Diante disso, observa-se que não existe um momento literário definido, sendo o poeta exemplo dessa atmosfera literária incerta.

Vale acrescentar que tão somente dez anos separam Bandeira dos últimos romances de Machado de Assis, de o Canã̃ de Graça Aranha e de Os Sertões de Euclides da Cunha. Sem mencionar Coelho Neto, Rui Barbosa e Olavo Bilac, que estavam em plena atividade literária. Mas devemos salientar que, se o contexto mostra traços notadamente representativos da tradição, a partir de 1915 já temos obras que despontam como denunciativas de uma nova ordem, a ver: $O$ triste fim de Policarpo Quaresma, de Lima Barreto, em 1916, no ano subseqüente, Há uma gota de sangue em cada poema, de Mario de Andrade, e Memórias sentimentais de João Miramar, que começa a ser escrito por Oswald de Andrade. ${ }^{4}$

O livro de estréia, aqui tomado como objeto de estudo, ainda que tenha marcas simbolistas e decadentistas, não é totalmente voltado para uma estética da rebeldia, nascida com o Romantismo. Embora o artista de fins do século XIX e início do século XX expresse nitidamente seu menosprezo pelo mundo da Belle Époque, Manuel Bandeira oscila nesses dois âmbitos, a tradição e a inovação, visto ter a presença de tonalidades um tanto quanto formais caras ao Parnasianismo na fatura de $A$ cinza das horas, sem considerar ainda os outros dois livros de sua fase pré-modernista.

Mas é importante ressaltar, que se Bandeira apresenta-se dividido entre a tradição e a modernidade, é porque percebe que ficaria muito distante da atmosfera cultural brasileira, o que não traduz um desconhecimento do poeta em relação a aspectos renovadores da linguagem e da literatura. Muito pelo contrário, com esse livro de estréia, o poeta visa apenas a conquista de um espaço literário, fato que justifica o seu caminho na mesma direção da atmosfera que o circunda. Essa consciência, além

\footnotetext{
${ }^{3}$ Ver dissertação de mestrado de Carlos Alberto Shimote Martins (1994, p. 64), Manuel Bandeira: Um lírico no alvorecer do século XX.

${ }^{4}$ Tal atmosfera de "indefinição" literária é reforçada pelas informações retiradas da obra de Júlio Castañon Guimarães (1984, p. 30), Manuel Bandeira.
} 
daquela restrita ao universo cultural do período em questão, mesmo que não transposta totalmente ou em ínfimos aspectos para sua poética, é percebida na citação de Paul Éluard, em uma entrevista ao Jornal de Letras, de 1951, retirada da dissertação de mestrado de Martins (1994, p.78-79):

conheci-o em Davos, na Suíça. Esse amigo teve uma influência decisiva na minha poesia. Foi ele quem me abriu os horizontes do que já se tinha feito na França e no mundo. Esse meu amigo é brasileiro e chama-se Manuel Bandeira. Ainda me lembro de como Bandeira brigava comigo, achando um absurdo que eu, sendo francês, não conhecesse Rimbaud. Começou a me emprestar livros e falar de poesia moderna, coisa que eu desconhecia por completo. Foi então que tomei contato com Rimbaud, Apollinaire e mesmo Baudelaire cujo grande valor ainda não me havia tocado. Bandeira não teve, apenas influência sobre mim. A poesia que cheguei a fazer depois saiu das longas conversas que tivemos então. Saiu daquela teimosa em me dar a conhecer os grandes poetas da minha própria língua. Eu ficava espantado com tamanha cultura do Bandeira e ao mesmo tempo sentia-me envergonhado.

Além dessa observação, é importante salientar que a obra A cinza das horas é composta por poemas de épocas totalmente disparatadas, de um período que abarca dez anos, ou seja, mesmo apresentando os poemas datados de Cladavel, nos anos de 1913 1914, com uma visão menos conservadora e mais rebelde, há outros que estão completamente imerso em condutas formais da época.

É a mesma atmosfera de indefinição que encontramos em Alcools, posto que essa obra data de um período que não apresenta nenhum princípio de ordem. No século XX francês, não podemos falar em "escolas", ou em tendências possíveis caracterizadas por palavras abstratas, como Classicisme, Romantisme, Naturalisme, Symbolisme. Agora não há mais escolas, ou espíritos em consonância. Há apenas poetas que observam ser necessário se agrupar em pequenas igrejas ou fazer manifestos, os mais disparatados possíveis. Por isso, devemos considerar a questão de Simon (1959, p.6) e sua resposta: 
et à quel groupe rattacher Valéry et Claudel, Gide et Proust, Moriac e Malraux? Quant à l'étiquette, apparemment comode, de l'Existentialisme, elle accroît la confusion propre à un processus littéraire de toute l'indétermination d'un concept philosophique approximativement employé.

Por isso, observamos Alcools como palco de todo esse disparate, ainda mais se considerarmos que está no início do século XX, em 1913, muito mais em consonância com o século anterior do que com o vindouro, que está ainda se firmando. O poeta mistura poemas dos mais tradicionais aos mais audaciosos em termos de modernidade. Essa mistura clássico/moderno pode ser exemplificada em "Larron" ou "Pont Mirabeau", que para a crítica mostravam Apollinaire como "poète de la tradition" e como "poète de l'inovation" com o poema da mesma coletânea, "Zone". Essa crítica não se deu conta de que tais aspectos para Apollinaire são indissociáveis, haja vista que ele só será adepto da invenção na medida em que essa for tributária da tradição. É o que reitera em Méditations Esthétiques:

on ne peut pas transporter partout avec soi le cadavre de son père. On l'abandonne en compagnie des autres morts. Et l'on s'en souvient, on le regrette, on en parle avec admiration. Et si l'on devient père, il ne faut pas s'attendre à ce qu'un de nos enfants veuille se doubler pour la vie de notre cadavre. Mais nos pieds ne se détachent qu'en vain du sol qui contient les morts.(APOLLINAIRE Apud DÉCAUDIN, 1993, p.127)

É uma boa definição da modernidade, pois o poeta não deve se prender ao passado ('le cadavre de son père'), pois corre o risco de mergulhar no academicismo, mas, ao mesmo tempo, não pode descartar um passado que o construiu.

Isso só reitera as marcas de modernidade nas obras aqui estudadas, posto que esse amálgama tradicional/moderno confirma a importância de Alcools e de A cinza das horas no desenvolvimento das Vanguardas Francesas e do Modernismo Brasileiro, mesmo que a primeira esteja bem mais avançada em termos de modernidade poética.

Em virtude disso, é mister apontar os traços que fazem dessas obras não meros livros sem importância para a tradição literária, sobretudo no que tange à modernidade 
poética, mas obras que contrariam ou anulam aquilo que críticos chegaram a mencionar, Alcools como uma "boutique de broncateur" e A cinza das horas como um livro característico da imaturidade literária do poeta.

Comecemos por A cinza das horas, onde são visíveis os primeiros "sapos" que prepararão e anunciarão o Modernismo. Trata-se de um livro com cinqüenta poemas, dentre os quais muitos podem ser associados ao Penumbrismo ou ao Crepuscolarismo, tendência poética presente em autores europeus muito caros a Manuel Bandeira. É importante ressaltar que tivemos no Brasil alguns poetas penumbristas, que não constituíram um grupo propriamente dito, mas que seguiam o mesmo viés que os poetas europeus: temas intimistas, quotidiano, melancolia, gosto pela penumbra e pelos meiostons, ritmo solto e fluido que abrirá as portas para o ritmo inovador do verso livre modernista.

Sendo assim, observamos que a maioria dos poemas de $A$ cinza das horas, segundo Lopez (1987, p.11), segue a tendência crepuscular, marcada pelos efeitos de atenuação e pelo tom melancólico, além da predominância da regularidade de composição, e de traços anunciadores do Modernismo, seja no ritmo (deslocamentos de acento, rimas toantes, tensão rítmica), seja na temática (ironia, metalinguagem, aceitação e transfiguração do quotidiano). Como exemplo dessa observação de Lopez, A cinza das horas é marcada por elementos decadentistas e melancólicos, tanto na presença de atmosferas crepusculares quanto em um léxico que denuncia tal tendência, como: névoa, crepuscular, luar, cinza, moribundo, tédio, desalento, desencanto, gemer, etc.

Outro exemplo que anuncia o Modernismo é a presença na obra, do "corvo", ave prenunciadora da condição moderna do poeta e da poesia na civilização industrial. Essa ave apresentaria as mesmas qualidades que os poetas "malditos", cantores do mal, possuíam. Tal recorrência motívica vai aparecer transfigurada no Modernismo Brasileiro, no anjo torto drummondiano, que condena o poeta a ser gauche na vida. Observamos que o motivo do "corvo" aparece mais de uma vez em A cinza das horas, mas a título de exemplificação, apontamos apenas a recorrência no poema "Ruço", marcado pela atmosfera das lembranças infantis e pelo mau destino: 
O vento do largo da praia,

O meu vestidinho de saia,

Aquele corvo, o vôo torvo,

O meu destino aquele corvo!

("Ruço")

É o que observamos, sobretudo, em Alcools, posto que já na ausência de pontuação, a obra denuncia um certo tipo de inovação poética, ou seja, um ritmo próprio, não mais aquele direcionado por regras de versificação e metrificação ou de ordenação de uma gramática consensual. Sabemos que, ao término da escrita, o poeta descontente suprime toda pontuação, o que não é prática apenas a partir dessa obra. Então, Apollinaire afirma que a pontuação não é essencial em uma obra, a sua associação ao ritmo e à medida do verso está na lógica mesma da escrita e da leitura.

Além da ausência de pontuação, observamos que Alcools segue as mesmas características crepusculares que anunciarão as Vanguardas, com a atenuação da temática os temas não são "nobres" como antes, tal tendência passa aos "banais", indo ao encontro da temática do cotidiano freqüente na poesia modernista, como em "À la Santé", poema que tem como tema os seis dias de prisão em Santé, ambiente nada poético e esmerado. Também nesse mesmo poema, observamos a estética da atenuação (aceitação) do mau destino sem queixa nem revolta, a atenuação psicológica, com languidez e passividade, a estrofação irregular e os enjambements, que tornam o ritmo do poema mais solto e o aproximam da prosa, o que certamente antecipa muitas características do modernismo: 
IV

Que je m'ennuie entre ces murs tout nus

Et peints de couleurs pâles

Une mouche sur le papier à pas menus

Parcourt mes lignes inégales

V

Que lentement passent les heures

Comme passe un enterrement

Tu pleureras l'heure où tu pleures

Qui passera trop vitement

Comme passent toutes les heures

(“À la Santé”)

Outro exemplo que reforça a importância de tal obra para o período literário em questão, embora tão mal-compreendida na época, é a questão do "cubismo na literatura", o que é tomado aqui de forma metafórica, posto que tal tendência existe apenas entre os pintores. Mas alguns poetas participaram da mesma sensibilidade, e, dentre eles, Apollinaire. O que eles têm em comum é admitir como princípio que a arte não tem a função de representar o mundo, mas sim de criá-lo. Então, acreditam na construção de um outro mundo, fora dos paradigmas vigentes.

É nesse cenário que se desenvolve a poesia de Apollinaire, apresentando uma nova forma, um novo mundo, aquele da justaposição de impressões, a multiplicação de ações, a decupagem, em que se obtém a unidade apenas pela intenção psicológica. Vários poemas dessa coletânea seguem tal tendência, mas citamos "La Chanson du Mal Aimé", que tem dois de seus versos emprestados de um outro poema, datado de 1901, dedicado a Linda Molina da Silva. 
Portanto, podemos dizer que o primeiro capítulo só corrobora a idéia de que tais obras e autores, mesmo líricos no alvorecer do século XX, tão execrados pela crítica da época, foram fundamentais para o desenvolvimento das tendências renovadoras da linguagem e da literatura. 
CAPÍTULO II 


\section{AINDA QUE HAJA UMA INFLUÊNCIA CONFESSA}

Partimos, agora, para o estudo temático-comparativo, visto que nesta etapa estudaremos as similitudes e as diferenças no que concerne ao tema central do "tempo não-reconciliado" e outras contíguas recorrências temáticas. No entanto, devemos lembrar que, para a reflexão de tal temática, não partimos unicamente da questão da influência confessa de Apollinaire em Bandeira, mesmo que a tenhamos constatado em muitas obras críticas que apontam o fato de o poeta brasileiro ter sido um leitor voraz dos poetas franceses, apresentando dados ainda mais precisos de tal relação, como na afirmação de que o poema "Solau do Desamado" foi inspirado em "La Chanson du Mal Aimé".

Gostaríamos de salientar que tal comparação vai além das fontes e influências intertextuais, considerando somente os traços biográficos dos autores estudados na medida em que esses esclareçam questões inexplicáveis no âmbito literário, o que do contrário empobreceria em demasia o nosso projeto e acrescentaria muito pouco ao desenvolvimento da temática. Apesar de sabermos que tal estudo é do domínio da Literatura Comparada, ou seja, da verificação de razões para as semelhanças apontadas, interligadas por uma problemática de recepção e influência (CUNHA, 2000, p. 13), não partimos apenas desse pressuposto, pois o que dá sustentação a nossa pesquisa são os pontos de contato temático que observamos na obra dos autores trabalhados, apontando para as estruturas e as funções comuns de suas poéticas e, ainda, para a importância de suas diferenças. Nesse sentido, tomamos como tema central "o tempo não-reconciliado" e consideramos os subtemas que o circundam: o cenário noturno, a efemeridade do amor, a inexorabilidade do tempo, a mulher longínqua, o Ubi Sunt? e a melancolia, sentimento sustentador de todos os motivos analisados.

Vale acrescentar ainda, a análise da figura do mal-amado, que norteará todos as tópicas destacadas, pois esse apresenta toda uma história de sentimentos e situações perdidas e de uma má sina constante, característica fundamental da temática que exemplificaremos no estudo dos poemas. Assim, faremos mais do que uma simples comparação, que privilegiaria a história literária ou a biografia dos autores - 
trabalharemos com a crítica temática, tão cara a Jean Pierre Richard, que propõe, segundo Cunha (2000, p. 21-22),

o envolvimento e o compromisso com a obra e, por meio de uma leitura criteriosa dessa obra, é que se tenta conhecer melhor o homem, o que traduziria uma certa intimidade com a biografia e o psiquismo do(s) autor(es). A crítica temática defende a reflexão acerca da obra e do escritor por inteiro, em forma de uma analogia, correspondendo a um desvelamento e a uma fruição de signos essenciais e individualizados, portadores de formas íntimas da mundividência do autor/poeta.

Nesse aspecto, analisamos as correlações temáticas existentes em "Volta" e "Rosemonde", "La Chanson du Mal-Aimé" e "Solau do Desamado", "Automme Malade" e "Crepúsculo de Outono", "Le Pont Mirabeau" e "O anel de vidro", "Crépuscule" e "Ao Crepúsculo", "Madrugada" e "Le vent nocturne". De tais poemas procuramos extrair os elementos formadores de um sistema de signos a ser decifrado, o que nos permite a exploração de uma outra lógica na poética de ambos os autores. Ao erradicar com a poética do mundo objetivo, e remeter-se à esfera do devaneio, da imaginação, apontam-se características de uma determinada época, cultura, humanidade, representadas em seus poemas, mas que reitera todo um conjunto de apropriações motívicas. Essa perspectiva de cunho maravilhoso é estudada em alguns poemas analisados, o mundo onírico, pois é somente no cosmo do devaneio que o malamado pode apaziguar a dor que sente em função do mal de amar e de sua própria condição desditosa de ser.

Tal consideração apresenta um leque do qual podemos nos valer para analisar a poética de Bandeira e de Apollinaire, pois a crítica temática abrange os domínios da psicologia, da antropologia, das motivações inconscientes, dos símbolos e mitos, para uma melhor interpretação e compreensão dos valores imaginários do mundo fantástico, o que na poesia se apresenta sob a forma de imagens. Logo, utilizamo-nos de todos os domínios citados para a realização da comparação entre as obras Alcools (1913) e A Cinza das Horas (1917), privilegiando o aspecto da tematização e explicitando-o por meio da análise dos poemas.

Longe de um comparativismo tradicional puramente de influências, tivemos por objetivo o trabalho com diferentes disciplinas - história, teoria e crítica da literatura, o 
que nos possibilita um estudo mais amplo e significativo, tomando o devido cuidado para não ultrapassar os limites do corpus literário, considerando influências ou aspectos que comprometam a perspectiva da poeticidade das obras. Nesse caso, a aproximação da poética apollinairiana e bandeiriana dá-se a partir do âmbito da tematização, contempla todas as disciplinas citadas, fazendo uma certa junção entre o mundo real e o imaginário dos autores, e ainda possibilitando diferentes leituras por parte do leitor:

tal proposta é enriquecida pela definição, que a partir de uma atitude extremamente lúdica, esboça a noção de tema na atualidade, resguardando todos os elementos que se embricam na construção dessa visão: (o tema) 'Il est donc le point d'affleurement d'un ensemble de relations à la fois construites par le texte et déduites par son lecteur, en collaborations" (Hamon, Ano: 496).

A coerência do tema é, portanto, fruto da ordenação de diversos valores e conteúdos que permeiam o texto e revelam, conseqüentemente, uma visão de mundo. $\mathrm{O}$ tema mistura ingredientes do "vivido" e do imaginário do autor, invocando, assim, a partir de quem o resgata, uma conivência e uma intimidade, uma "colaboração" com o corpo poético (CUNHA, 2000, p. 23)

Ainda em relação ao trabalho comparativo por meio da tematização, devemos enfatizar a questão para a qual Leyla Perrone Moisés nos chama a atenção: trata-se dos dois aspectos existentes na noção de tema - a valorização de imagens recorrentes e obsessivas, distanciadas do todo da obra, que traz o risco de limitação da análise, excluindo dessa forma considerações relevantes; e o aspecto com o qual trabalhamos, partindo da pesquisa no contexto global da obra, e das recorrências motívicas na tradição literária, estabelecendo uma relação entre as figuras temáticas e a expressão poética.

Nesse viés, partimos de uma questão de suma importância para o desenvolvimento de nosso estudo: por que comparar Apollinaire e Bandeira? Para respondermos a tal pergunta, valemo-nos de dois trabalhos relevantes para o nosso projeto: a dissertação de mestrado de Elisabete Maria Gaban Passalacqua, Apollinaire, Bandeira e a Modernidade, na qual a temática estudada é a questão da Modernidade na poética apollinairiana e bandeiriana, e o livro da professora Silvana Amorim, intitulado Guillaume Apollinaire: fábula e lírica, além de outras referências bibliográficas sugeridas pela autora. Embora os dois trabalhos comparativos tenham se desenvolvido 
praticamente no mesmo período, tomaram caminhos opostos, mas complementares: a nossa pesquisa se ateve à primeira fase de ambos os autores, a parnasiano-simbolista de seus primeiros livros, enquanto Passalacqua estudou os aspectos da modernidade em toda a obra dos poetas, o que atesta a "originalidade" de nosso projeto.

Dessa dissertação, retiramos apenas os dados importantes para a nossa pesquisa, como os fatos que dão maior sustentação a tal comparação, tais como a circunstância que fez com que Manuel Bandeira fosse leitor de Apollinaire e de outros poetas franceses (os dois são contemporâneos, com a diferença de apenas seis anos), o fato de ambos terem tido uma formação parnasiano-simbolista, a presença de características do Romantismo em suas obras, e ainda o aspecto da frustração, seja em Apollinaire, pelos amores não correspondidos, ou na constante presença da morte em Bandeira. Esse aspecto foi por nós trabalhado de forma diferenciada, pois consideramos que ambos os poetas sofreram do mal de amar. Pode-se dizer que, seja na tuberculose ou não, notamos a presença do mal de amar na poética bandeiriana, pois, segundo Rosenbaum (1993, p. 181 e 182), “o tratamento que Bandeira atribuía às suas relações amorosas freqüentemente revela frustrações, platonismo, abandono, insatisfação, perda, traição. A distância, já se viu, impera muitas vezes, entre o poeta e a amada”.

Tal proposta é enriquecida ainda pelo livro de Betina Ribeiro Rodrigues da Cunha, A poética da natureza na obra de Éluard e Bandeira. Deste livro extraímos também a informação de que Bandeira foi leitor de poetas franceses, o que nos possibilita a reflexão sobre possíveis pontos de contato temáticos presentes na obra de escritores de origens diferentes. Além do fato de tal livro ter suscitado a proposta de trabalhar com a crítica temática, que nos proporciona uma maior fundamentação de nossa reflexão.

A propósito das relações poéticas enriquecidas com a leitura dos dois trabalhos e de tantas outras obras, podemos responder à questão do por quê comparar Bandeira e Apollinaire. Partimos então da observação do percurso pessoal de ambos, com vistas à aproximação temática de suas obras, e exploramos as primeiras produções poéticas de autores que são contemporâneos, de nacionalidades e culturas distintas, mas que apresentam muitas semelhanças no que concerne à temática elegíaco-amorosa decorrente de um tempo não-reconciliado, visto que sofreram do mal de amar, embora não façamos uma comparação de cunho biográfico. 
Pelo fato de trabalharmos com a Literatura Comparada, consideramos necessário fazer um breve histórico de tal linha de pesquisa, o que nos remete ao momento em que surgiram as literaturas grega e romana, já que aí foram comparados os seus méritos. Um outro momento decisivo dessa história se deu no século XIX, quando há a consideração da Literatura Comparada como método e como ciência, em que comparar e defrontar seria uma maneira de se comprovar uma conjetura.

Outro viés observado nesse século é a questão da visão cosmopolita que estimulou viagens e encontros entre grandes pensadores e intelectuais da época, como, Mme de Staël, Goethe e Sainte Beuve, interessados no contato com outras literaturas.

Em meio a essa visada cosmopolita, a partir de 1828, a disciplina Littérature étrangère comparée foi primeiramente lecionada nas universidades francesas, sendo a "influência" o ponto de partida e a base teórica para estudos comparatistas até a primeira metade de século XX, passando a ser profundamente criticada a partir dos anos 50. Sobretudo pelo momento americano, como denomina Cláudio Guillén, propondo um modelo supranacional ligado às questões mais gerais da literatura, buscando uma estreita relação entre história, teoria e crítica, o que atesta a derrocada do factualismo positivista da Literatura Comparada tradicional. É importante ressaltar que tal literatura, calcada na causa e no efeito, não foi criticada apenas pelos americanos, mas por um teórico francês, René Étiemble, que colaborou sobremaneira para o desenvolvimento da história dessa disciplina, embora tenha suscitado muitas discussões e críticas, por se apoiar exclusivamente em um material norte-americano e europeu.

A partir de então, a literatura comparada enfrenta novos questionamentos, devido aos estudos de Adrian Marino, que não concorda com os princípios epistemológicos da escola francesa, e ainda a perspectiva crítica dos americanos. Percebe-se, dessa forma, que Marino propõe considerar a literatura comparada sob uma perspectiva teórica, transformando as relações particulares até então consideradas em relações universais.

Vale, portanto, lembrar que no final do século XX, segundo Sandra Nitrini (1997, p. 60), observa-se que há a inauguração de uma nova fase na história da Literatura Comparada, já que ela continua em crise no Ocidente e já que crescem os estudos diferenciados nesta área pelos países do Terceiro Mundo e do Leste, colocando em cheque o cânone dos escritores europeus. Para isso, esses estudos apontam para a importância da transformação criadora do "modelo emprestado". Tal modelo deve adequar-se às tradições e particularidades históricas da literatura que sofre a influência externa. 
Ainda abordando a questão da evolução do comparativismo, notamos que, depois de quase dois séculos de estudos nessa área, passa a haver a valorização das relações no texto e entre os textos, dando relevância à colaboração de Julia Kristeva que, por meio dos estudos sobre Tynianov e Bakhtin, constrói a noção de "intertextualidade", que se definiria como processo de produtividade do texto literário, o que para ela existe porque "todo texto é absorção e transformação de outro texto. Em lugar da noção de intersubjetividade, se instala a de intertextualidade, e a linguagem poética se lê, pelo menos, como dupla (CARVALHAL, 1986, p. 50).

Considerando esse conciso histórico a respeito da literatura comparada, remetemo-nos ao nosso corpus de estudo, ou seja, o paralelo entre os poemas de Bandeira e os de Apollinaire, objetivando destacar características ou pontos de contato temáticos em suas poéticas, e de ambos ao longo da tradição literária, ou melhor, como a obra brasileira $A$ cinza das horas nos obriga à releitura de todo um passado literário, no qual está incluído o poeta francês:

como uma obra forte nos obriga a uma releitura de todo passado literário, onde passaremos a encontrar não as fontes daquele novo autor, mas obras que se tornam legíveis e interessantes porque existe esse autor moderno; obras que passam a ser, então "precursoras" dessa nova obra. Diz ele: O fato é que cada escritor cria seus precursores (MOISÉS, 1990, p.95)

Nessa perspectiva, diante das teorias apresentadas sucintamente, seguimos a da intertextualidade de Julia Kristeva, que de forma mais coerente, a nosso ver, garante o diálogo entre as duas obras estudadas, que, embora criticada pelo teórico espanhol Cláudio Guillén, esse reconhece o benefício considerável da teoria para o comparatismo. Pois, como atesta Sandra Nitrini (2000, p.166) sobre a observação que Guillén faz a respeito da teoria de Kristeva, "Seria mais uma teoria que nos abre o caminho para a leitura, mas que não oferece diretamente caminho. Em outras palavras, não resolve o método da literatura comparada" - o comparatista exagera ao fazer semelhante afirmação, além de depauperar a teoria da intertextualidade, baseando-se no comentário de duas citações, retiradas de seus contextos, e sem maiores explicações.

É importante destacar que tal análise segue o viés das inter-relações, sem o confronto hierárquico valorativo da literatura comparada tradicional. Por isso, devemos 
mencionar que, embora haja a influência confessa por parte de Bandeira, notadamente nos poemas "Chanson du Mal Aimé" e "Solau do Desamado", não podemos, de maneira alguma, fazer uma simples leitura de recepção passiva do poeta brasileiro. Isso se dá, ao contrário, de maneira crítica e dinâmica, fazendo da obra de Bandeira "a transformação do velho em novo, do alheio em próprio, do déjà vu em original. Por reconhecer que a originalidade nunca é mais do que uma questão de arranjo" (MOISÉS, 1990, p. 98-99).

Partindo da citação de Kristeva, de que "todo texto se constrói como um mosaico de citações, todo texto é absorção e transformação de textos" (Moisés, 1990, p.94), a obra A cinza das horas, apesar de muitos contatos com Alcools, apresenta a partir da "fonte" uma configuração própria, sem a condição de superioridade ou inferioridade, enfatizando a natureza criativa do processo de produção textual, e inserindo-se no conjunto maior do literário.

Essa natureza criativa permite-nos considerar as "fontes - Apollinaire e seus poemas" somente para observar de que maneira essas foram assimiladas e transformadas por Bandeira, diferentemente de uma dependência canônica eurocêntrica. Logo, cabe ressaltar que nessa leitura, além de considerarmos a teoria da intertextualidade, tomamos para análise as propostas teóricas do século XX de Bakhitin, Tyniánov, Borges e Oswald de Andrade, que, semelhantemente à de Kristeva, privilegiam a busca das diferenças sobre as analogias, ênfase que caminha para a transformação dos textos.

Diante disso, gostaríamos de corroborar que nosso projeto segue uma leitura oposta ao comparativismo positivista e factualista, pois, se o fosse, reduziríamos a obra do nosso grande poeta Manuel Bandeira ao simples fato de ter dito que seu poema "Solau do Desamado" foi inspirado em "La Chanson du Mal Aimé", o que seria uma grotesca injustiça para com a literatura brasileira.

Feitas estas considerações de ordem teórico-metodológica, damos continuidade à pesquisa, partindo para a comparação entre a poética de Bandeira e de Apollinaire, tomando como tema central "o tempo não-reconciliado", iniciando com os títulos das obras estudadas A Cinza das Horas e Alcools, que de forma semelhante apresentam o elemento fogo, como alimento de suas coletâneas. Logo, notamos que o nome alcools, segundo Jean (1998, p. 117) “coloca sua poesia sob o signo implícito de Dionísio, Deus do ditirambo, do vinho, do álcool que transforma o fogo criador de Apolo em bebida que queima e embriaga". Com essa citação vimos que o elemento fogo é o combustível 
da coletânea nomeada Alcools, visto que é o álcool que transforma o fogo em bebida que queima e embriaga, direcionando-nos para a temática de nosso projeto, pois essa mudança demonstra a efemeridade ou a instantaneidade do amor que circunda toda obra.

Por isso, esse fogo nos remete a uma leitura elegíaca da obra, na medida em que a chama só permanece acesa durante o efeito de embriaguez dos seus alcools, processo que demonstra toda a esfera fantástica em que o eu lírico mal-amado está inserido, possibilitando o resgate do amor perdido apenas no campo onírico, mesmo que isso se dê de forma efêmera, como a chama que se transforma rapidamente em fumaça.

O mesmo ocorre com o título A cinza das horas, pois a cinza, resquício do fogo que em um passado indeterminado queimou, retrata, como em Apollinaire, se pensarmos a obra como um todo, a efemeridade do amor e a sua instantaneidade, e ainda por meio das "horas" que passaram, a inexorabilidade do tempo, restando apenas a "cinza" e uma dita e feliz história de amor finda. Ainda, como em Alcools, o mundo fantástico causado pela embriaguez da bebida é notado no título de Bandeira, pois o fogo apresentado em A cinza das horas ultrapassa o mundo real, para se embeber do maravilhoso, objetivando nesse como do devaneio a recuperação do amor que se esvaeceu com o passar do tempo:

o fogo, que não é somente um elemento constituinte da realidade terrestre, é uma realidade particular cuja simbologia se calca em uma análise do imaginário. Condutor de realidades supra-poéticas que, ultrapassando a experiência científica ou os árduos e impessoais trabalhos de Física, privilegiam a intuição pessoal e recuperam a primitiva e original condição de devaneio, materializa o real imaginário e realiza a síntese perfeita entre a complexidade da rede simbólica e a manifestação dela decorrente (CUNHA, 2000, p. 127)

Em ambos os títulos observamos que o elemento fogo é representativo da busca pela recuperação do objeto amado, seja pela cinza, símbolo da imortalidade e eterna presença do homem, explicitado por Fênix, pássaro mitológico que em si concentra a longevidade e a ressurreição cíclica e que renasce das cinzas, seja pela bebida (álcool), que se transforma em fogo criador e possibilita, mesmo que na embriaguez do corpo onírico, o recobrar do perdido, o amor que nesse momento é elegíaco, por caracterizar apenas uma lembrança feliz. 
Em relação ainda ao referencial teórico explicitado, devemos salientar que a problemática decorrente da teoria da intertextualidade destacada por Cláudio Guillén, ao dizer que ela não resolve o método da Literatura Comparada, está presente em qualquer outra desenvolvida em território nacional ou em outros países.As inúmeras teorias criadas em épocas diferentes, entrando em consenso ou não, avançando aspectos umas das outras, ou buscando um discurso próprio, acabam dialogando entre si, e, deploravelmente, nessa querela infinita, não permitem responder à pergunta que há tempos questiona o verdadeiro sentido da Literatura Comparada.

Por esse motivo, a resposta a tal pergunta: O que é Literatura Comparada? permanece sem afirmações categóricas, posto que essa, como afirma Sandra Nitrini (2000, pp. 289-293), acompanha as mudanças habituais da história da literatura, de suas teorias e de seus países em relação a outros.

A justificativa para tal posicionamento crítico-analítico reside no propósito de contribuir, em consonância com os objetivos pretendidos no âmbito dos estudos comparados sob um de seus domínios a "tematologia", para a aferição de pontos de contato entre a poética bandeiriana e a apollinairiana.

Para tanto, não podemos deixar de mencionar que tomamos o cuidado de não cair em uma análise tematológica vazia, aquela que segue uma certa exaustividade enciclopédica e um certo ostracismo. Assim, observamos que tal isolamento seria irrealizável, posto que a obra literária não é um fenômeno em si, mas participante de uma cadeia em que cada anel em consonância forma ao término o conjunto da tradição literária. É o que Trousson (1965, p. 46-47) esclarece:

mais il convient aussi d'éviter de tomber dans l'erreur de faire d'une oeuvre um phénomène frappé de "splendide isolement"; cet insularisme littéraire ne saurait se concevoir que comme une vue de l'esprit, dénuée de toute réalité, car l'étude d'une oeuvre en soi ne suffit pas à l'expliquer, ni même à la comprendre. Imaginons une monographie qui ne situerait pas l'oeuvre de Hugo dans le contexte intellectuel et politique du romantisme et ne chercherait pas à savoir ce qu'elle doit à son siècle et au précédent. Nous suffit-elle? Une oeuvre fait toujours sur un arrièrre- et plus particulièrment peut-être lorsqu'elle traite un thème doté de sa tradition propre dans laquelle l'auteur a choisi de s'inscrire. 
Isto posto, é mister discorrer sobre as profícuas controvérsias que a noção de tema tem sucitado segundo Raymond Trousson. Cita uma infinidade de termos empregados à definição de tema em francês, a ver: mithe, thème, motiv, idée, élément, type, figure, ou em alemão, stoff, fabel, motiv, figur, bild, idee, element.

Essa miscelânea de oposições, como em qualquer outra área, tem o seu aspecto positivo, mas deixa lacunas para interpretações errôneas e críticas infundadas de polemistas sobre o verdadeiro papel da crítica temática na atividade comparatista.

Nesse viés, baseado no texto de Philippe Chardin, inserido na obra Compêndio de Literatura Comparada (2004), organizado por Pierre Brunel e Yves Chevrel, tradução do original francês intitulado Précis de Littérature Comparée, fizemos uma súmula dos principais pares antitéticos que variam de crítico para crítico.

Philippe Chardin elenca tais pares privilegiando os seguintes aspectos:

1. O grau de generalidade - colocado como o mais freqüente, cita Simon Jeune que opõe os tipos lendários ou históricos e os tipos sociais ou profissionais aos temas ou assuntos gerais da Stoffgeschichte: elementos (floresta, cidade, oceano...), idéias (liberdade, natureza...), sentimentos (amor, inveja...).

2. O grau de abstração - segundo Claude Bremond que distingue da seguinte forma o conceito de tema: "Há em Rousseau um conceito de contrato social, mas um tema de devaneio" (Poétique, p. 415).

3. O grau de elaboração - que complementa o grau da generalidade, opondo "motivo" a "tema", colocando o segundo do lado da menor generalidade. O que Trousson denomina como um processo de particularização, de decantação, de cristalização de alguns motivos que se encontram na origem da constituição de um tema literário. Já Claude Pichois e André Rousseau definem motivo ao que os pintores chamam de tema.

4. O estudo de crença numa época e sociedade concretas - segundo André Dabezies que toma o conceito de tema como sinônimo de fábula, opondo-se ao mito, o qual denomina como relato ou personagem simbólica. A transformação do mito é considerada como o término de um processo de declínio enquanto na classificação antecedente o tema representava o Aufhebung do motivo.

5. A presença ou ausência de considerações "formais" - em relação a essa distinção à Todorov, Manfred Beller lastima que os estudos temáticos tenham se resumido 
a um simplório levantamento de materiais brutos no qual não há a ínfima preocupação com o rigor conceitual, chegando a propor a substituição da notória expressão "Stoffgeschichte" pelo termo "Tematologia", posto que se trata de um conjunto inseparável de forma-conteúdo, matéria-modo. Seguindo esse viés, a tematologia não estaria muito distante do estudo das formas literárias em sentido amplo. Ainda, outra questão bastante delicada a resolver é a distinção tema-mito, que devido a vários estudos e há um bom tempo de equívocos, verificou-se a preocupação por sua resolução, o que em obras francesas e estrangeiras foi freqüente, ao longo da história dos estudos comparados. Podemos dizer que, atualmente, a palavra "mito" impõe-se categoricamente a tema, visto que equivale a uma constante arquetípica, de uma imagem canônica, de uma figura emblemática; "em contrapartida, aquilo que chamamos, por vezes, estudo dos "mitemas" pode pertencer igualmente à tematologia" (BRUNEL \& CHEVREL, 2004, p. 170).

Diante de todas essas reflexões metodológicas, das quais muitos polemistas se utilizaram para colocar em derrocada tal seguimento, ainda se sustenta a grande importância dos estudos temáticos, pois como salienta Mikhail Bakhtin, o "estudo temático-comparativo pressupõe uma atitude mutante e viva, no campo da história das idéias" (RODRIGUES FILHO Apud BAKHITIN, 2001, p.118), e não um domínio da atividade comparatista que jaz no esquecimento.

É o que observamos em uma das passagens do capítulo "Los Temas: Tematología" da obra Entre lo uno y lo diverso de Cláudio Guillén, em que salienta a importância das recorrências temáticas e motívicas como sendo o Leitmotiv da obra, pelo seu caráter diligente, chegando a citar que Thomas Mann caracteriza a sua arte de thematisch, só vindo a reforçar que o domínio da tematologia não é "un genre maudit, un genre mort- né", como muitos o querem: 
el Motiv así llega a ser um Leitmotiv, apoyado en el dinamismo de la reiteración. Piénsese en el uso musical del tema como variación, que reconoció Thomas Mann al calificar su propio arte de thematisch. Piénse en Senos (1923), de Ramón Gómez de la Serna, uno de los libros menos eróticos de la moderna literatura española, con sus incansables variaciones lúdicas sobre una misma sinécdoque: senos $=$ mujer.

Outra questão importante a ser destacada é o fato de nas modalidades dos estudos temáticos a idéia de tema estar vinculada à raiz grega do verbo tithemi, que significa posar, seguindo a razão de ser cumulativa de algo vivo, sempre alentada pelo fazer literário. Essa relação dinâmica da tematologia cairá no que Barthes diz sobre a prática literária que é produzida "como fios de uma temática centrada na pessoa do autor e assim definida como estrutura de uma existência". 5

Ao considerar essa vinculação da prática literária com uma temática centrada na pessoa do autor, observamos que tanto na poesia de Bandeira quanto na de Apollinaire há uma contígua série organizada de obsessões motívicas, em que se destaca a inexorabilidade do tempo, a efemeridade do amor, o Ubi Sunt?, o noturno, a melancolia, a má sina, a mulher longínqua, entre outros. Logo,

a vida de um escritor é sua biografia artificialmente recomposta, inevitavelmente lacunar. Sua existência é uma emergência no instante: a página que escreve é inseparável do instante que ele vive, mas também de um passado no qual ele mergulha suas raízes (BRUNEL\&PICHOIS\&ROUSSEAU, 1990, p. 112)

A obsessão individual de um autor pode ser observada em outros, como no caso de Bandeira e de Apollinaire, apresentando temas e motivos que se propagam a partir de um pensamento individual, de um período ou grupo em questão. Dessa forma, essas reiterações temáticas e motívicas podem ser de cunho social, político, literário ou artístico. Logo, os temas de uma determinada época podem se disseminar por meio de imagens que estão em voga ou suceder novamente, seguindo o viés da intertextualidade em relação a autores predecessores, como ressonância da temática eterna, que é o caso 
de Alcools e de A cinza das horas, com recorrências como, o tempo, o amor, o Ubi Sunt?, a melancolia, o outono, o crepúsculo, etc. É o que observamos em toda a história da literatura, temas de tempos remotos presentes na atualidade em questão, sobre o que Brunel\& Pichois\& Rousseau (1990, p.114) declaram: "a literatura seria como um palimpsesto raspado sem cessar e reescrito sem cessar".

Considerando a ressonância da temática eterna, partimos de alguns universais temáticos, que recentemente têm sido objeto de estudos de muitos comparatistas: a guerra, a cidade e o mar. Com esses universais temáticos, observamos, na obra de Pierre Brunel e Yves Chévrel (2004,p.174-175), uma gama de trabalhos consagrados e recentes que seguem tal domínio, como o de Charles Dédéyan (Une guerre dans le mal des hommes) sobre temas e microtemas do romance de guerra, de Leon Riegel (Guerre et Littérature), de Julien Hervier (Deux individus contre l'histoire: Drieu la Rochelle, Ernest Jünger)aborda problemas fundamentais da temática da guerra e literatura no século XX, entre outros. Nesse viés, seguindo com tema da cidade, temos uma antologia temática notável feita por Michel Tibert, que se desenvolve a partir de três articulações: a cidade a contemplar, antes da revolução industrial do século XVIII, a cidade a conquistar, desde o fim do século XVIII, e a cidade a decifrar, a partir de 1950. Ainda sobre a mesma temática, há um recente estudo de Roger Chemain dedicado à cidade africana. Outro universal temático apontado é o mar, cujos estudos contemplam a tese de Monique Brosse (Récit maritime français dans ses relations avec les littératures anglaise et angloaméricaine), destacando aspectos sociológicos "a vida cotidiana das tripulações, a opinião perante os dramas do mar...", psicocríticos "as relações do homem com o mar e com o barco foram sempre fortemente antropomorfizadas e até mesmo sexualizadas" e literários, por meio da análise de subgêneros "diário de bordo, romance histórico-marítimo, contos de folclore, epopéia, poesia, marinhas...”. Também, é importante ressaltar que o trabalho de Monique Brosse não contempla apenas autores renomados como Hugo, Byron, Coleridge, Poe, Melville, Loti, mas também um conjunto de escritores marítimos que "saem do ordinário" como está em Proust.

Para erradicar a concepção de que os estudos temáticos acabaram por se transformar em uma "discipline maudite ou, pire encore, dédaignée", como afirma Trousson, observamos que muitos trabalhos notáveis seguem ainda tal tendência, como

\footnotetext{
5 Ver tese de doutorado de José Maria Rodrigues Filho (2000, p. 119), "O Barão", de Branquinho da Fonseca: De sua Fortuna Crítica a um Estudo Temático-Comparativo.
} 
a revista trimestral Corps écrit, que surge a partir de 1982 e que reúne textos de criação literária e de reflexão crítica segundo o viés da inspiração freqüentemente temática. Sendo assim, a título de ilustração, citamos os números que abordam, segundo Brunel \& Chevrel (2004, p.175-176), o domínio dos estudos temáticos: 4. La Récompense; 6. L'animal fabuleux; 7. Le sommeil; 8. Le nom; 9. La demeure; 11. La mémoire; 12. Le silence; 13. L'ivresse; 14. La nuit; 16. L'eau; 19. La faute. Um outro exemplo de que tal domínio continua atuante na atividade comparatista é a coleção temática de orientação comparatista das Éditions Bordas, que apresenta ilustres fascículos que abordam temas como a aventura, o sonho, o tédio, etc. Isso só vem a corroborar a nossa tese de que a tematologia não está esquecida, além de ter sido responsável, nos últimos anos, pela mediação de programas temáticos, por uma certa inserção da Literatura Comparada no ensino secundário.

Nessa perspectiva, baseado nos universais temáticos ou em uma temática eterna, fizemos um breve levantamento de contíguas recorrências temáticas nos poemas de Bandeira e de Apollinaire, seguindo a tradição literária que é preservada pela intertextualidade:

na zona de cooperação social que se institui ao longo do tempo, a tradição literária funda uma comunidade de autores e textos num sistema sígnico poético-histórico em constante elaboração. É pela tradição que se consolidam as convenções estilísticas, como o uso motívico, determinando uma certa sensibilité stylistique entre os autores, épocas e nacionalidades díspares, numa espécie de hybridisme culturel (RODRIGUES FILHO, 2001, p.17)

A propósito dessa zona de cooperação, é importante ressaltar as referências intertextuais nas obras A cinza das horas e Alcools, no tocante a autores, seus motivos e temas já tradicionais na literatura.

Isso posto, destacamos, primeiramente de Manuel Bandeira, o poema "A Camões", que mostra toda a portugalidade presente em sua obra, ou o gosto pelos clássicos portugueses, nascido na infância e retomado por meio do contato com seu professor Silva Ramos e com seu colega Souza da Silveira. Outra apropriação observada é a retomada da tradição medieval e renascentista portuguesa, explicitada pela utilização de artifícios estilísticos característicos de antigas narrativas compostas 
em versos e acompanhadas por músicos, como em "Solau do Desamado". Além da referência à literatura portuguesa, devemos mencionar que é o próprio Manuel Bandeira quem confessa a influência de um outro autor, Apollinaire, especificamente do poema "La Chanson du Mal Aimé". Eis daí a temática do desamor, tratada em Camões, e retomada num tom elegíaco por um processo de recriação por Apollinaire e em seguida por Bandeira, como em uma cadeia de consonância.

Outra referência intertextual é o poema "A Antônio Nobre", que reforça o viés pesaroso da obra estudada, pois se baseia no infortúnio do poeta Antônio Nobre, que morreu com apenas trinta e três anos, mas que não consegue ser maior do que o mau destino do eu lírico bandeiriano caracterizado em tal poema:

Revejo em teu destino o meu destino

Foste conde aos vinte anos...Eu nem isso...

Eu não terei a glória...nem fui bom.

(“A Antônio Nobre”)

Bandeira retoma por meio do soneto, com uma nota insistente de mal-estar, a temática da melancolia e da morte recorrentes no poeta simbolista.

No poema "Paráfrase de Ronsard" identificamos uma recorrência intertextual do poeta Ronsard, cuja temática é conhecida universalmente e recorrente na tradição literária, a inexorabilidade do tempo/Carpe Diem, e é retomada por Bandeira:

Senhora, o tempo foge... o tempo foge...

Com pouco morreremos e amanhã

Já não seremos o que somos hoje...

("Paráfrase de Ronsard")

Em "Don Juan" a referência intertextual é explicita, pois parte de uma figura romanesca, o "Don Juan", tomado na tradição literária tanto por poetas quanto por filósofos, como símbolo-chavão de paixões e loucuras humanas. Nessa perspectiva, observamos que o motivo "desamor", recorrente em A cinza das Horas, é exemplificado por meio do astuto sedutor, o tema "Don Juan". É importante salientar que o tema já decantado e cristalizado, como afirma Trousson, tem características próprias, ou transformadas pelo fazer literário, 
pois, se assim não o fosse, correríamos o risco de chegar a um tratamento comum do tema e do motivo em diferentes épocas. Para uma melhor compreensão, é interessante destacar a observação que Trousson (1965, p.12-13) faz do motivo, ao apresentar um conceito mais amplo e do tema seguir uma menor generalidade:

qu'est-ce qu'un motif? Choisissons d'appeler ainsi une toile de fond, un concept large, désignant soit une certaine attitude - par exemple la révolte - soit une situation de base, impersonnelle, dont les acteurs n'ont pas encore été individualisés - par exemple les situations de l'homme entre deux femmes, de l'opposition entre deux frères, entre un père et un fils, de la femme abandonné, etc. Nous avons affaire à des situations déjà délimitées dans leurs lignes essentielles, à des attitudes déjà définies, à des types même par exemple le révolté ou le séducteur - mais qui restent à l'état de notions générales, de concepts: dans ce sens, l'idée de bonheur ou celle de progrès, la rébellion métaphysique ou l'avarice sont des motifs.Qu'est-ce qu'un thème? Convenons d'appeler ainsi l'expression particulière d'un motif, son individualisation ou, si l'on veut, le résultat du passage du général au particulier. (TROUSSON, 1965, p.12-13)

Nesse processo de particularização, vimos o motivo "desamor" da obra estudada se transformar no tema "Don Juan", que não passa de um representante da figura aqui trabalhada, praticamente em todos os poemas, o mal-amado. Convém ressaltar que o segundo se aproxima do primeiro apenas no que diz respeito ao destino do sedutor, frustrado e desfeito pelo próprio amor, mas que se distancia na medida em que o malamado não possui e não pratica essa capacidade de sedução, já que ele é regido pela força do mau destino.

É o que vimos em Alcools, um vasto sistema de trocas, como "Zone", datado de 1912, que foi fortemente influenciado pelo poema "Pâques", de Blaise Cendrars. Isso se deu no momento em que Apollinaire acompanha Cendrars, ao recitar seu poema no ateliê de Delaunay, bastante tocado, escreve "Cri”, que se intitulará mais tarde "Zone". Essa recorrência intertextual não molda o poema de Apollinaire ao de Cendrars; ao contrário, malgrado tais semelhanças, a força criadora e transformadora do fazer literário é nítida: 
"Zone" et "Pâques" entretiennent de fortes ressemblences: proximité des thèmes, analogies de structures extérieures, d'agencement mélodique. Toutefois les "Pâques" se présentent sous la forme de distiques séparés, alors que la démarche est libre dans "Zone" qui procède par groupes de longueurs différentes (LECHERBONNIER, 1983, p.)

O intertexto é ainda observado em "Cors de Chasse", cuja constante desamor é abordada, apresentando a imagem do destino dos amantes fadada ao infortúnio, essencialmente patético. É na segunda estrofe especificamente que destacamos o intertexto, a referência ao escritor inglês Thomas de Quincey. O mais curioso é que a própria história de Apollinaire, o amor por Annie que o fez correr as ruas de Londres a sua procura, remete-nos às caminhadas pelas ruas de Londres de Quincey, onde conheceu Ann, uma prostituta que lhe salvou a vida. É nessa atmosfera, que se desenvolve o poema : o eu lírico intoxicado pelo amor e Quincey pela droga, ou melhor, essa última sendo representativa do sentimento que envenena como os "colchiques". Ainda nessa mesma estrofe, observamos outra referência intertextual, mesmo que indireta: a inexorável passagem do tempo que nos remete a Villon, "où sont les neiges d'antan?", sendo transposta para o verso de Apollinaire "Passons passons puisque tout passe" (v.9).

Outra referência intertextual está no poema "Salomé", que apresenta um diálogo com as escrituras sagradas na medida em que recorre à história de adultério de Herodes com Salomé, presente nos quatro evangelhos. Nessa, o rei Herodes trai o próprio irmão Philippe com sua cunhada "Salomé", sendo descobertos pelo profeta João Batista, que critica tal atitude, pois diz "não ser lícito viver com a mulher do irmão". Nesse ambiente de traição, Herodes oferece uma festa em comemoração de seu aniversário, em que presencia e aprecia sua sobrinha a dançar, ficando embevecido com tamanha graça, e chegando a lhe oferecer, como prêmio, tudo aquilo que pedisse, até mesmo metade de seu reinado. Diante disso, rapidamente consulta sua mãe, Salomé, que o orienta a pedir a cabeça de João Batista, como vingança por suas interferências proféticas. Então, Herodes não hesita em cumprir com sua palavra, manda decapitar o profeta e traz a sua cabeça em uma bandeja perante todos.

A despeito de tal referência intertextual, devemos salientar que não há, em hipótese alguma, uma despersonalização do processo criador, haja vista a transformação nítida da história bíblica de adultério no poema de Apollinaire. Em "Salomé”, embora 
seja decapitado como na história bíblica, o profeta é colocado em uma posição que denuncia a sua relevância. Ele é agora tratado por senhor, "sire", vocábulo que é usado para nomear apenas imperadores e reis, mostrando que o profeta é protagonista, chegando a ser mais importante do que o próprio rei Hérode. Além disso, a sobrinha do rei parece dançar para o profeta e não mais para Hérode, indagando o por quê de tamanha tristeza de sua mãe, tendo essa mostrado sinal de arrependimento. Por isso, a menina pede a uma espécie de bobo da corte "louco" que não chore, e, ao invés de pegar o seu cetro "marotte" guarnecido de guizos e sinos, símbolo da loucura, pegue a cabeça de João Batista e dance, mas sem tocá-la, visto que sua tez já está fria:

Venez tous avec moi là-bas sous les quinconces

Ne pleure pas ô joli fou du roi

Prends cette tête au lieu de ta marotte et danse

N'y touchez pas son front ma mère déjà froid

(“Salomé”)

Com um certo tom de humor, observamos a mulher arrependida, como que castigada pelo seu relacionamento adúltero. Isso explica, na obra estudada, que o motivo do adultério se particulariza no tema Salomé, mas, ao mesmo tempo, na temática constante tanto em Alcools quanto em A cinza das horas, o desamor, que reforça a contínua atmosfera de pesar das obras analisadas.

Isso posto, partimos para o universal temático tempo que, desde os primórdios, é tema versado na literatura, na história, na filosofia, nas artes e nas ciências, e que é o fio condutor do trabalho aqui realizado, haja vista que é pelo "tempo não-reconciliado" que se cria toda a atmosfera pesarosa nas obras em questão.

No que tange aos complexos temáticos em uma obra, é importante ressaltar que um tema não é tomado isoladamente. É por isso que a temática eterna "tempo" não rejeita a contigüidade ou a união à temática do noturno, do Ubi sunt?, do amor, da melancolia, entre outros. Essa relação segue a noção de redes e cadeias de temas e motivos, permitindo uma explicação de ordem comparatista voltada para a ponderação de uma rede intertextual coerente. 
Ao considerar a justaposição de temas e de motivos, decidimos dar preferência à análise da tópica "tempo", visto ser um tema caro aos poetas aqui estudados, também recorrente ao longo de todas as obras e gerador de todos os outros subtemas em questão.

Para a predileção da recorrência motívica do tempo, é importante salientar que a figura do mal-amado está submersa em uma atmosfera de infortúnio causada por uma temporalidade que é sempre não-reconciliada, haja vista o caráter da recusa simplista do tempo cíclico aqui desenvolvido, que seria uma maneira de recuperar o que findou.

No plano das recorrências motívicas do tempo em Alcools e A cinza das horas, caímos no que o método analítico do teórico Joseph Texte, citado por Rodrigues Filho (2001, p. 122), considera: "o estudo temático-comparativo como legado da crítica que investiga a ocorrência de temas (lugares-comuns) no cotejo de Homero com Virgílio, Demóstenes com Cícero e outros". É importante ressaltar que a constante "tempo" não será analisada apenas no que concerne aos autores Bandeira e Apollinaire, mas sim por meio de um percurso analítico histórico-literário e adentrando no âmbito filosófico, apresentando como tal tópica foi desenvolvida diacronicamente, e conduzindo a um profícuo acolhimento da compreensão da textualidade literária.

Para desenvolver esse percurso diacrônico, partimos da concepção de tempo que dá o sentido ou a consciência da duração e das diferenças entre passado, presente e futuro.Segundo observações de Whitrow (1993, p.19 a 23) retiradas da obra O tempo na história, essa distinção é característica e uma das mais importantes faculdades mentais a distinguir o homem de outras criaturas vivas.

A despeito disso, vale destacar que, apesar de tal faculdade ser peculiar à humanidade, deve-se tomar o devido cuidado para não desconsiderar o fato de que alguns seres humanos passam e passaram pela história sem a concepção de tempo que nos é consensual. A título de ilustração, apontamos, segundo Whitrow, três grupos em que a concepção de tempo lhes é própria:

1. Os hopis do harizona, sendo sua língua estudada por Benjamin Lee Whorf, que verifica a inexistência de palavras, formas gramaticais, construções ou expressões referentes ao tempo ou a qualquer de seus aspectos.No lugar dos conceitos de espaço e de tempo, eles empregam outros termos "objetivo" e "subjetivo", respectivamente. Ainda, é 
importante acrescentar que a língua hopi, diferente do inglês, prefere verbos a substantivos, mas seus verbos não apresentam tempos.

2. Os azandes do sudeste do Sudão, observados por Evans-Pritchard, que acreditavam na superposição do presente e do futuro, ou seja, os acontecimentos futuros do homem desse povo procediam de condições futuras já existentes. Sendo assim, quando os oráculos indicavam que um homem ficaria doente, isso significava que ele já estava mal, posto que seu futuro estava interligado ao presente

3. Os nuers, outra raça sudanesa estudada por Evans-Pritchard, que vivem às margens do Nilo Branco e não possuem nenhum equivalente para o nosso vocábulo tempo. Eles não concebem o tempo como algo que passa, que pode ser administrado com parcimônia ou gasto sem proveito, mas sim pela referência às suas atividades sociais, ou a acontecimentos do tipo de enchentes, pestilências, guerras, entre outros.

Com tais exemplos, observamos que a concepção de tempo/recorrência motívica aqui estudada não é única e comum a toda humanidade, já que não é e não foi igualmente concebida em muitos povos primitivos e civilizações relativamente avançadas.

Considerando as diferenças que existem em relação a tal concepção, fizemos uma súmula das bases naturais de medição que foram usadas para registrar e marcar o tempo ao longo da história, com base ainda nas observações de Whitrow (1993, p.28 a 31).

Essa computação do tempo teve o seu primeiro método, o mais antigo, por meio de fenômenos nitidamente reconhecíveis, como a contagem dos dias por meio das auroras, o que é visto em Homero: "Esta é a décima segunda aurora desde que cheguei a Ílion”, (Ilíada, XXI.80-1).

Já o aborígine australiano marcava o momento para uma determinada ação por meio da colocação de uma pedra em um tronco bifurcado de uma árvore, de maneira que o sol ali incidisse na ocasião estabelecida.

Outras tribos nos trópicos precisavam a altura do dia pela direção do sol ou pela projeção da sombra de uma vareta na vertical.

Dentre as diferentes convenções a propósito do estabelecimento do início da unidade dia, os egípcios elegeram a aurora, à medida que os babilônicos, judeus e mulçumanos escolheram o pôr-do-sol. Também os romanos escolheram inicialmente a 
aurora, mas observaram a variação do período iluminado após a meia-noite e passaram a considerá-la. É interessante ressaltar que até o advento do relógio no século XIV, a unidade dia na Europa Ocidental era marcada pela aurora.

Vale destacar que, depois da unidade dia, a unidade mais importante de tempo é o ano. Logo, observamos que no escandinavo alemão e anglo-saxão antigos, os anos eram computados pelos invernos. Já em eslavônio, não eram os invernos que determinavam os anos, mas sim os verões, enquanto que na Bavária medieval eram os outonos.

Tais indicações de tempo derivadas de fases climáticas e outras fases naturais não eram peremptórias, necessitava-se de uma maior exatidão. É quando o homem se dá conta de que com os astros essa precisão desejada é possível. Então, percebe-se que as estrelas proporcionam um meio mais veloz e categórico para determinar a época do ano. Também, nota-se que as estrelas podem auxiliar o homem na determinação das estações, mas não na divisão do ano em partes. Diante disso, a Lua entra como astro responsável pela produção de uma unidade temporal entre o ano e o dia, sendo por isso caracterizada como o primeiro cronômetro na história.

É importante destacar que, para marcar e registrar intervalos de tempo mais curtos que o ano e o dia, muitos primitivos utilizaram intervalos fisiológicos para tal medição, "um piscar de olhos", ou atividades do cotidiano, o tempo necessário para o cozimento de uma determinada quantidade de arroz.

Feitas essas considerações de ordem histórica, partimos para o âmbito filosófico, seguindo uma concepção deleuzeana de tempo, pois é nesse que o "tempo nãoreconciliado", motivo recorrente em nosso trabalho, se faz presente, sendo responsável pela construção da figura do mal-amado.

Esse tempo "não-reconciliado", como o nome já diz, não segue um círculo físico ou natural em que tudo há de voltar - como os amores e outras situações vivenciadas do sujeito poético mal-amado - mas é aquele que procura desfazer tal círculo bem centrado demais, descartando o velho senso comum do eterno retorno: 
C'est-à-dire: nous en restons au cercle trop simple qui a pour contenu le présent qui passe, et pour figure le passé de la réminiscence. Mais précisément l'ordre du temps, le temps comme forme pur et vide a défait ce cercle-là. Or il l'a défait, mais au profit d'un cercle moins simple et beaucoup plus secret, beaucoup plus tortueux, plus nébuleux, cercle éternellement excentrique, cercle décentré de la différence qui se reforme uniquement dans le troisième temps de la série (DELEUZE, 1968, p. 122)

O círculo eternamente descentrado faz com que o tempo estudado em Bandeira e Apollinaire saia do aprisionamento que se vê ao longo da história, desde a sua domesticação. Aqui, ele não é como na filosofia antiga, uma porta giratória, mas sim emancipado de qualquer forma extrínseca. É justamente por isso que nasce o infortúnio do sujeito mal-amado, visto que nessa leitura deulezeana não é tudo que retorna, reforçando a sua condição pesarosa de ser, pois seus anos de gozo jamais voltarão, "sem as ilusões que repertoriaram: a transcendência, os universais, o eterno".

Isso posto, é mister discorrer sobre a história do tempo de Gilles Deuleze, baseada em seu interregno em meio ao seu curso em torno do cinema, ministrado em 1983-4, em Paris VIII, inserida na tese de Pelbart (1996, p.163 a 170).

Essa história corresponde a três períodos, um tempo selvagem, na seqüência uma domesticação do tempo e uma liberação do tempo, o que não se entende por momentos sucessivos, em uma única linha temporal, mas interligados e embaralhados, sendo "afirmados" por uma quarta linha, "o espiralamento descentrado do tempo".

O primeiro período, um tempo selvagem, corresponde ao tempo próprio do mito, pois nesse existe uma distância que separa uma origem de uma soberania. É essa distância que Deuleze aponta como um tempo do terror, do sem-fundo, tempo desordenado da luta dos deuses. Nesse cenário do tempo não-domesticado, o tempo da distância está entre a origem das coisas (Caos) e a ordem do soberano (Zeus), não colocado ainda nos eixos por um deus.

No segundo período, observamos a domesticação do tempo, o momento em que o modelo mítico dá lugar à Filosofia. Nesse, os dois termos afastados do mito, origem e soberania se aproximam, fazendo com que o mundo seja feito e ordenado em um único gesto. Assim, a distância que existia no mito é substituída pela identidade inédita da gênese e ordem da origem e dominação. É dessa forma que o movimento do mundo 
torna-se circular, e o tempo se vê acuado, domesticado, tendo Platão como aquele que estaria narrando o encurvamento do tempo, dando a sua forma cíclica.

O terceiro período, uma liberação do tempo, equivale à ineficácia do aprisionamento do tempo (domesticação), que, por mais ordenado que seja, apresenta problemas. É o momento em que o tempo sai dos gonzos, vê-se liberado do movimento circular.

Considerando os três tempos aqui apresentados, de forma bastante breve, chegamos à linha que serve como base para o desenvolvimento da recorrência motívica "tempo" em nossa pesquisa, o espiralamento descentrado do tempo. É nesse que encontramos fundamento para o pesar derivado de um tempo não-reconciliado na figura do mal-amado, pois esse é um tempo pensado à luz da diferença e como multiplicidade pura. Esse tempo não é uma recusa fortuita à "circularidade", mas a uma cadeia cíclica mecânica que sempre remete ao Mesmo:

L'éternel retour n'affecte que le nouveau, c'est-à-dire ce qui est produit sous la condition du défaut et par l'intermédiaire de la métamorphose. Mais il ne fait revenir ni la condition ni l'agent ; au contraire, il les expulse, il les renie de toute sa force centrifuge. Il constitue l'autonomie du produit, l'indépendance de l'oeuvre. Il est la répétition par excès, qui ne laisse rien subsister du défaut ni du devenir-égal. Il est lui-même le nouveau, toute la nouveauté. Il est le troisième temps de la série, l'avenir en tant que tel (DELEUZE, 1968, p.122)

É justamente o que vai de encontro à figura do mal-amado, posto que o seu eterno pesar é fundamentado na impossibilidade de recuperar as coisas findas. Esse tempo passado não pode ser resgatado pelo presente, pois o tempo agora está liberado do movimento e não está mais preso ao Presente e ao Passado enquanto centro. Desse modo, esse tempo descentrado admite a concepção de eterno retorno somente "como seleção, que deixa subsistir apenas o novo, a novidade", e não a repetição de encadeamentos de acontecimentos de forma idêntica, como assim o espera miticamente a figura do mal-amado, com seus amores, sentimentos e situações irrecuperáveis.

Essa repetição do novo, o eterno retorno, não recai sob o conjunto do tempo, pois como já mencionamos, não é tudo que volta. Por isso, os amores que se esvaeceram como decorrência da inexorabilidade do tempo nos poemas analisados jamais 
retornarão, visto que esse tempo descentrado luta bravamente contra a repetição do hábito e da memória:

une philosophie de la répétition passe par tous les "stades", condamnée à répéter la répétition même. Mais à travers ces stades elle assure son programme: faire de la répétition la catégorie de l'avenir - se servir de la répétion de l'habitude et de celle de la mémoire, mais s'en servir comme des stades, et les laisser sur son chemin - lutter d'une main contre Habitus, de l'autre contre Mnémosyne - refuser le contenu d'une répétition qui se laisse tant bien que mal "soutirer" la différence (Habitus) - refuser la forme d'une répétition qui comprend la différence, mais pour la subordonner encore au Même et au (Mnémosyne) - refuser les cycles trop simples, aussi bien celui que subit un habituel présent (cycle coutumier) que celui qu'organise un passé pur (cycle memorial ou immémorial) - changer le fondement, de la mémoire en simple condition par défaut, mais aussi bien la fondation de l'habitude en faillite de "l'habitus", en métamorphose de l'agent - expulser l'agent et la condition au nom de l'oeuvre ou du produit - faire de la répétion, nom pas ce à quoi l'on "soutire" une différence, ni ce qui comprend la différence comme variente, mais en faire la pensée et la production de "l'absolument différent" - faire que, pou elle-même, la répétition soit la différence en elle-même (DELEUZE, 1968, p.125-126)

É o que tomamos como justificativa para a má sina do eu lírico mal-amado, que vive a constante dor da perda por não poder reter e nem recuperar o tempo que é inexorável, haja vista que não é condicionado à sucessão de movimentos, por conveniência e de forma circular simplista: ele está reconciliado consigo mesmo, sem a dependência da memória de um passado ou da expectativa de um futuro. Nesse sentido, o eterno retorno, como estratégia para o mal-amado recuperar o perdido, é impossível, posto que a repetição sempre estará centrada na diferença, e não na retomada ordenada derivada de um ciclo que corresponderia ao equilíbrio que de fora viria salvar aquilo que era caos. 
Esse ciclo é pensado por Deleuze: "afirma o caos, não o enverga nem o corrige"6 . Por isso, o fato de o filósofo recusar algumas teorias desenvolvidas, tai como: O Tempo vergado em Círculo pelo demiurgo platônico, o Tempo como número do movimento segundo Aristóteles, o Tempo submetido à Lei da causalidade com Kant, o Tempo retornado do Mesmo, nos Círculos concêntricos de Hegel. Assim, o ciclo pensado por Deleuze afirma a condição primeira do eu lírico mal-amado, o infortúnio por estar imerso em uma atmosfera da repetição da diferença em meio ao caos, sem qualquer expectativa de recuperação do vivido.

Portanto, essa repetição não será, em hipótese alguma, a retomada de um tempo perdido, mas a categoria do futuro, ou seja, fazer do futuro o incondicionado, o objeto da repetição. O que corrobora a nossa idéia de um tempo não-reconciliado, pois, ao procurar o resgate pela repetição, encontrar-se-á não um passado olvidado, mas um futuro que não está vinculado a um encadeamento derivado do presente e do passado. Esse tempo é puro, sem a carga conciliatória redentora de antemão, é o tempo ele mesmo, descarrilado, e que afirma o retornar não do Mesmo, mas sempre da Diferença.

Tendo ratificado a questão do "tempo não-reconciliado" no sujeito poético malamado a partir das colocações de Deleuze, chegamos a um ponto relevante de nosso trabalho, o motivo do tempo recorrente na literatura, posto que já acompanhamos suas implicações no viés histórico e filosófico.

Nessa perspectiva, é o que observamos na percepção do tempo como motivo na literatura, tendo os escritores de diferentes épocas se debatido nas garras da angustiante pergunta Ubi sunt?, cada um a seu modo, buscando encontrar resposta ao mistério que é a eterna inexorabilidade do tempo.

Ao focalizarmos a recorrência motívica "tempo" em Bandeira e em Apollinaire, não é suficiente destacar que ela faz parte de uma tradição literária, como já mencionamos em nosso trabalho, mas é preciso também salientar que a visão de tais poetas é a visão de homens do século $\mathrm{XX}$, embora ainda carregados da herança parnasiano-simbolista do final do século XIX. Por isso, o conjunto temático que data de séculos na história da literatura serve como patrimônio comum aos escritores, para que esses o utilizem e o adaptem a seu momento histórico-literário. Nessa "reciclagem" de temas e de motivos, que é constante desde a Antigüidade, podemos observar que a

\footnotetext{
${ }^{6}$ Citação retirada da tese de doutorado de Peter Pál Pelbart (1996, p. 181), O Tempo NãoReconciliado. Imagens de tempo em Deleuze, do capítulo 4 - O Círculo do Outro.
} 
integração entre o já cristalizado e a nova seiva permite ao fazer literário um caminho mais amplo e abrangente, no sentido de possibilitar todo o trabalho artesanal do escritor, sendo esse, como sabemos, um artesão das palavras.

A rememoração do tema e do motivo faz com que consciente ou inconscientemente, ressuscitemos aqueles que jazem na necrópole dos imortais, mas que foram os precursores de tal tradição, e que possuem um "surplus" de significante, como classifica o crítico inglês Frank Kermode, aqueles que são sempre retomados e completados a cada leitura, como Catulo, Horácio, Villon, passando por Machado, Proust, Cervantes, Joyce, entre tantos outros, o que só nos faz pensar que a recorrência motívica "tempo" é uma busca obsessiva, tendo cada autor a ilusão de sua manipulação, de sua explicação e de seu resgate protelado a cada obra. 


\section{CAPÍTULO III}




\section{3 - 0 diálogo entre a poética bandeiriana e apollinairiana}

\section{1- O medievalismo na lírica apollinairiana}

Considerando a temática central de nossa pesquisa, a "escritura da perda" como resultado da passagem do tempo, observamos um subtema relevante para o desenvolvimento do nosso trabalho: "O medievalismo na lírica apollinairiana".

Ao estudarmos esse subtema observamos que ele está relacionado, em alguns aspectos, com a tópica “A imagem da mulher amada (volubilidade, "santidade", etc.)". Desse modo, para realizarmos o estudo dessa temática, utilizamos como objeto o poema “'La Chanson du Mal-Aimé’'(1904), escrito por Apollianire a partir da recusa ao pedido de casamento feito a Annie, um de seus grandes amores findos. É importante destacar que iniciamos a análise pelas cinco primeiras estrofes, em seguida partimos para as estrofes 55 a 59. Essa seleção se deu para viabilizar a possibilidade de aproximação das poéticas, o que nos garantiu uma maior fundamentação do trabalho comparatista aqui desenvolvido. Também é de suma importância salientar que o poema apresenta 295 versos, dos quais estudamos apenas vinte e cinco.

La Chanson du Mal-Aimé

à Paul Léautaud.

Et je chantais cette romance

En 1903 sans savoir

Que mon amour à la semblance

Du beau Phénix s'il meurt un soir

Le matin voit sa renaissance. 
(Strophes 1 à 5)

Un soir de demi-brume à Londres

Un voyou qui ressemblait à

Mon amour vint à ma rencontre

Et le regard qu'il me jeta

Me fit baisser les yeux de honte

Je suivis ce mauvais garçon

Qui sifflotait mains dans les poches

Nous semblions entre les maisons

Onde ouverte de la Mer Rouge

Lui les Hébreux moi Pharaon

Que tombent ces vagues de briques

Si tu ne fus pas bien aimée

Je suis le souverain d'Égypte

Sa soeur-épouse son armée

Si tu n'es pas l'amour unique

Au tournant d'une rue brûlant

De tous les feux de ses façades

Plaies du brouillard sanguinolent

Où se lamentaient les façades

Une femme lui ressemblant

(Strophes 55 à 59)

[...]

Juin ton soleil ardente lyre

Brûle mes doigts endoloris

Triste et mélodieux délire

J'erre à travers mon beau Paris

Sans avoir le coeur d'y mourir

Les dimanches s'y éternisent

Et les orgues de Barbarie

Y sanglotent dans les cours grises

Les fleurs aux balcons de Paris

Penchent comme la tour de Pise

Soirs de Paris ivres du gin

Flambant de l'électricité

Les tramways feux verts sur l'échine

Musiquent au long des portées

De rails leur folie de machines 
Les cafés gonflés de fumée

Crient tout l'amour de leurs tziganes

De tous leurs siphons enrhumés

De leurz garçons vêtus d'un pagne

Vers toi toi que j'ai tant aimée

Moi qui sais des lais pour les reines

Les complaintes de mes années

Des hymnes d'esclave aux murènes

Le romance du mal aimé

Et des chansons pour les sirènes.

Notamos já em seu título, "La Chanson du Mal-Aimé”, a criação de um neologismo "Mal-Aimé", palavra criada pelo autor a partir do modelo "bien-aimé", opondo-se a ele. O protagonista "mal-aimé" apresenta o fim de sua história de amor vivenciada em um passado indeterminado, conta a tristeza de ter sido abandonado, gerando um grande pesar, que é representado de diferentes maneiras, em todas as esferas do poema. Esse poema é caracterizado como uma longa elegia de sessenta estrofes de cinco octossílabos, apresenta-se como uma crônica do amor triunfante e infeliz. Seus versos são distribuídos regularmente em quintetos, e a sua epígrafe demonstra que se trata de um romance, no sentido medieval e mais antigo do vocábulo (AMORIM, 2003, p. 122).

Nesse poema, o fato essencial para sua compreensão, é o amor de Apollinaire por Anni Playden e o relacionamento que ele manteve com sua amada inglesa, entre 1902 e 1904. Esse acontecimento serviu como inspiração para a elaboração do poema, o poeta apresentando um amor incondicional por Annie, e não aceitando facilmente a sua recusa, sendo necessárias algumas viagens para reencontrá-la, em novembro de 1903 e em maio do ano posterior, para certificar-se de que havia perdido definitivamente o seu grande amor, em janeiro de 1905. Logo, para exemplificar esse fato citamos uma carta que Apollinaire escreveu como resposta às indagações de Madeleine Pagès, em julho de 1905, o que nos esclarece sobremaneira a leitura do poema pelo viés da inspiração e do seu caráter essencialmente lírico: 
"Aubade" não é um poema à parte, mas um intermédio intercalado na Chanson du Mal-Aimé que, datado de 1903, comemora meu primeiro amor, aos vinte anos, por uma inglesa que encontrei na Alemanha; isso durou um ano, nós tivemos de voltar cada um para seu país, depois não nos escrevemos mais. E expressões desse poema são severas demais e injuriosas para uma moça que não me compreendia nem um pouco e que me amou, mas ficou desconcertada em amar um poeta, ser fantasioso; eu amei-a carnalmente, mas nossos espíritos estavam longe um do outro. Entretanto, ela era fina e alegre. Tive muito ciúmes dela sem razão e pela falta vivamente sentida, minha poesia que pinta bem meu estado de alma de então, poeta desconhecido no meio de outros poetas desconhecidos, ela distante e não podendo vir a Paris. Fui vê-la duas vezes em Londres, mas o casamento era impossível e tudo se arranjou com uma partida para a América, mas sofri com isso, testemunho é esse poema em que me acreditava mal-amado enquanto era eu que amava mal, e também 'L'Émigrant de Landor Road' que comemora o mesmo amor...(APOLLINAIRE, 1994, p.1046 - Apud AMORIM, 2003, p.123)

Mas, ao constatarmos o fato biográfico que serviu como principal inspiração para a composição do poema, não podemos a ele nos limitar, pois estaríamos destruindo toda a sua poeticidade, e reduzindo a poética apollianairiana ao relato biográfico. Assim, podemos partir da concepção de Décaudin (1993, p.34-35), de que embora tenha relacionado cada um de seus poemas a um fato de sua existência, Apollinaire não teve a pretensão de contar a sua vida por meio de sua poética. 'Mais Apollinaire n'a pas voulu raconter sa vie bien qu'il ait dit que chaque poème commémorait un événement de son existence'".

Feita essa ressalva, podemos prosseguir com a análise propriamente dita do poema, que trata de uma triste história de amor contada já em sua epígrafe com a marca mítica “Du beau Fhénix”, o que reitera a caracterização do eu lírico como mal-amado. Nessa história de amor finda, observamos duas personagens principais, o homem que diz "Je" (aquele que fala), identificado somente com o "Mal-Aimé" do título. Ele conta a história que viveu em um passado, “Un soir de demi-brume à Londres'”(v.1), no outono de nevoeiro e cerração, o que já denota uma ambientação gélida e enganosa, pela incerteza que transmite pela falta de nitidez. A outra personagem é a mulher, que foi “bien aimée'(v.12), o que aparece primeiro como "tu”' (a quem se fala) no discurso do Mal-Aimé (monólogo interior da estrofe 3) e em seguida é designada em 
terceira pessoa, pelo pronome "lui" (de quem se fala): "Une femme lui ressemblant'(v.20). Sua identidade não pode causar dúvida porque ela é "'l'amour unique" (v.15) desse “je’, não aparecendo diretamente na história contada (MORHANGE-BÉGUÉ \& Lartigue, 1993, p.31)

Nessa triste história de amor os personagens estão inseridos em um cosmo demasiadamente nostálgico no qual o amor mortifica o coração daqueles que amam. A nostalgia presente na figura do "mal-aimé" pode ser vista quando ele, em uma tarde em Londres, acredita vir ao seu encontro a mulher que ainda ama (embora a relação com sua “bien-aimée", tenha acabado), mas se trata apenas de um "voyou', que lhe lança um olhar de desprezo e se vai. Desse modo, o protagonista pesaroso segue o "voyou", afirmando a persistência do amor que tem por essa mulher, mesmo que ela não faça mais parte de sua vida, pois é impossível esquecer o passado, visto que esse envenena o presente e colabora para a construção de um sujeito poético mal-amado, com marcas dolorosas de uma intensa e feliz história de amor finda: "Le passé ne peut s'oublier, il empoisonne le présent. Le souvenir gâte le fragile bonheur de l'instant et il ternit l'avenir, impénétrable et finalement, indifférent. Errance du poète, cet éternel insatisfait: passé vide, présent infernal, avenir absent'’(LECHERBONNIER, 1983, p.15).

Em seguida há um segundo encontro em que a ilusão de ver sua amada se manifesta, ele observa uma mulher vulgar, de rua, com um olhar pesado, que se assemelha ao seu grande amor, mas que não passa de uma devassa. Então, o protagonista toma consciência da "fausseté de l'amour"'(v.25) e sente o desalento de ver a imagem da mulher que ama nos transeuntes corrompidos da grande cidade. Desse modo, nota por meio dessa imagem que a sua amada não está mais presente, que ela só permanece em suas alucinações e sonhos. Assim, ele demonstra todo o pesar e a efemeridade que existe no ato de amar. Considerando todo esse desalento, podemos trabalhar com uma concepção de amor medieval que, na Idade Média, apresentava um fundo notadamente negativo, pois a morte inevitável certificava o homem de que "toda a beleza e toda a felicidade eram inúteis porque estavam destinados a acabar em breve", (Huizinga, 1978, p.131) - processo que ocorreu com a figura do "mal-aimé", sendo que de toda a sua feliz história de amor hoje restam apenas o pesar e as tristes lembranças de sua amada.

A busca pelo amor findo continua quando o "mal-aimé", tomado pela vergonha, lança-se obstinadamente a perseguir o "voyou", como que em um enfeitiçamento 
mágico e afirma sua fidelidade à mulher amada, que se assemelha a esse personagem sem escrúpulos: "Si tu ne fus pas bien aimée"' (v.12), "Si tu n'es pas l'amour unique", (v.15) ; vê-se dessa forma uma concepção trágica do amor, pois ela "foi" a sua amada em um passado que não retorna. Já no segundo encontro, o jovem não persegue a personagem, ele rejeita o amor, devido à semelhança da mulher "saoule” com a sua amada: mesmo sexo, "une femme" (v.20), mesmo "regard", mesma "cicatrice" (v.21-22). Em seguida a perda do amor é total: essa mulher é deprezível, "saoule”, “taverne” (v.23), seu egoísmo é notório, "regard d'inhumaine”' (v.21), e a sua beleza é degradada, “cicatrice"'. Logo, não é digna de seu amor. Conseqüentemente, ele condena o seu caráter enganador, sua "fausseté",(v.25), o mesmo termo que emprega ao amor. Dessa forma, podemos dizer que essas personagens servem de reveladoras dos sentimentos, ainda inconscientes, do "mal-aimé"; a vergonha de continuar a amar uma mulher que não o ama mais, a inutilidade desse amor sem esperanças e, enfim, a rejeição do amor que não sustenta suas promessas (MORHANGE-BÉGUÉ \& LARTIGUE, 1993, p.33).

A memória do protagonista serve como guia eficaz pois, por meio das reminiscências que guarda de sua história de amor, transforma o seu desalento em poesia, o que se fazia na Idade Média por meio da composição sobre o verdadeiro sentido da existência humana e de tudo o que a cerca:

verificam-se muitos pontos semelhantes entre Les Fleurs du Mal e os Alcools de Apollinaire, coletâneas nas quais a construção formal tem grandes destaques e significado, onde 'ressoa a simbólica da alta Idade Média que costumava refletir, nas formas da composição, a ordem do cosmo criado', e onde se vê o homem dividido entre a matéria e o espírito. São obras que representam o sofrimento transformado em poesia; a dor, então é poetizada (AMORIM, 2003, p.131).

Embora haja a presença marcante de uma poesia medieval que aborda a questão do pesar que existe no ato de amor, por conseqüência de sua efemeridade, tal como todas as coisas terrenas, observamos efeitos-surpresa e traços humorísticos dignos de uma composição moderna, como na estrofe 40a: "Et moi j'ai le coeur aussi gross", "Qu'un cul de dame damascène'. Nessa mescla do passado com o presente, 
destacamos a importância das palavras na poesia apollinairiana, pois esse utiliza vocábulos dos mais raros até os mais triviais, chegando até mesmo aos vulgares:

tous les mots semblent provoquer en lui un étonnement 'naif'. Il se saisit des termes les plus vulgaires comme putain, maquereau, cul, pet, bordel, démerdard non pour le seul plaisir de choquer, mais parce qu'ils possèdent en eux une charge d'émotion et une force d'expression irréductibles et irrépressibles (LECHERBONNIER, 1983, p.21).

Mediante essa mistura entre o moderno (vocábulos mais simples), a utilização da memória, e o antigo, a concepção negativa do amor efêmero como todas as coisas terrenas, apontamos o poema como um dos grandes exemplos da modernidade, embora apresentando muitos aspectos da poesia medieval.

Desse modo, podemos partir para mais um tópico medieval na poesia apollinairiana:

\section{A inacessibilidade da mulher amada}

Aqui ainda encontramos o amor elegíaco, pois a inacessibilidade da amada, causada pela ruptura da história de amor, coloca a mulher como um ser longínquo cujo resgate por meio da memória e da composição poética ameniza a dor que a figura do “mal-aimé”, sente por tê-la perdido. Essa angústia por não possuir o seu grande amor pode ser observada na estrofe 55, na qual o episódio do poema se encontra situado no tempo “Juin" (v.1) e no espaço "Paris" (v.4). Nessa estrofe os "doigts indoloris" (v.2) evocam por associação de idéias o coração dilacerado do jovem, no qual o imenso desespero amoroso foi cantado nas cinqüenta e quatro estrofes precedentes. Assim se explica a "triste et mélodieux délivre'. A crise psicológica e moral se resolve por ela mesma, a tentação do suicídio não se concretiza como confirma o verso 5: "Sans avoir le coeur d'y mourir'. Nesse caso “coeur" é sinônimo de "courage", mas essa palavra,como sabemos, também tem uma ressonância amorosa. Nesse sentido, notamos que o protagonista "mal-aimé" resgata lembranças de seu passado dito feliz, alimentando-se das reminiscências, o que permaneceu de sua história de amor, que se resume na amada inatingível. 
Nesse viés, podemos fazer referência às cantigas de amor nas quais o homem sofre pela inacessibilidade de sua amada, sendo o ponto-base o amor cortês: amorsentimento, amor-aspiração, amor-inatingível. Assim, nessa canção repleta de lamentos notamos que, para suavizar a intensa dor do mal de amar, o mal-amado se utiliza de uma arma eficaz para romper tamanha distância de sua amada, o resgate do passado: "As imagens fragmentadas, simultâneas e/ou colocadas retratam o passado, a memória, suas lembranças entrecortadas e guiadas - ou desviadas - pelo fluxo da consciência. Assim, abarca a união do antigo e do novo sem detrimento de nenhum desses universos." (AMORIM, 2003, p.184).

Podemos prosseguir com as estrofes 56 e 57, nas quais o protagonista "mal-aimé parece não encontrar pessoa alguma na cidade, o que é uma maneira de exprimir a sua solidão. Em seguida, a respeito da comparação: "Penchent comme la tour de Pese'”(v.10), notamos que o humor equilibra a tristeza dos versos precedentes. Tudo se passa como se o jovem tivesse "maîtrisé" sua dor e pudesse desde então renunciar à sua tristeza: “les tramways [...]/ Musiquent [...]/ [...] leur folie [...]”'(v.13-15), que fazem eco no "mélodieux délire" da estrofe 55 (MORHANGE-BÉGUÉ \& LARTIGUE, 1993, p.42). Todos esses sentimentos de solidão, dor e renúncia à tristeza estão inseridos na criação poética do poeta "mal-aimé", a qual não passa de um melodioso delírio, que é um dos traços da poesia elegíaca. Dessa maneira, observamos toda a problemática que existe no ato de amar, pois, além da passagem do tempo que devora qualquer sentimento por maior e mais intenso que seja (tornado o objeto amado inatingível), o verdadeiro amor ou uma certa reciprocidade no amar é impossível, dadas as diferencas entre homem e mulher: "'Plus que tout, l'amour porte le poids de la fuite du temps. Si le poète est le 'malaimé', c'est moins en raison de déboires sentimentaux qui lui seraient propres que parce qu'un véritable amour est impossible à cause des 'éternités différentes de l'amour de l'homme et de la femme",'. (DÉCAUDIN, 1993, p.83)

Portanto, nessa poesia escrita na ausência, o protagonista lamenta a sua condição de "mal-aimé", pois a inacessibilidade de sua amada o faz refletir sobre a inconstância que é o ato de amar. Nesse sentido, constatamos mais uma tópica que colaborou para a reflexão sobre nosso tema: 


\section{A musicalidade na poética apollinairiana}

Ao estudarmos essa tópica, vemos que "La chanson du Mal-Aimé" é uma canção amorosa, cheia de lamentos que transformam a tristeza em canto. Assim, nas duas últimas estrofes - 58 e 59, trabalhamos os aspectos mais importantes relacionados ao amor elegíaco, tais como: os diversos barulhos que se escutam nessa cidade, como palco das angústias do "mal-aimé”, cujo mais notável é um grito indiferente de amor (provado pelos “tziganis" os “siphons”, os “'garçons”) lançados pelos “cafés”'(v.16), lugar onde se misturam todos esses sons que se encontram personificados. O último verso exprime a intensidade do amor do protagonista, pela repetição do pronome pessoal e pelo emprego do advérbio de intensidade "tant": “toi que j' ai tant aimée'”. Mas o emprego do passado indica o caráter findo desse amor. Assim, ele pertence ao passado e perdeu seu poder torturador ; logo, o "mal-aimé", busca na estrofe seguinte sua natureza e seus dons de poeta. Nessa busca, indica o forte traço nostálgico desse amor, pois crê não valer mais a pena amar ou sofrer fisicamente, mas sim poetizar o seu sentimento, cantar o seu pesar, amenizando dessa maneira a sua dor com criações poéticas.

Todos os sons personificados encontrados na cidade colaboram para uma poesia calcada na musicalidade, sendo essa uma melodia do pesar. Logo, na estrofe 59, ainda notamos elementos do universo musical e lírico, com a presença de termos amorosos "lais" (v.21), poemas líricos da Idade Média, "romance" (v.24), canto de amor, “complaintes" (v.22), canções populares lamentosas, "hymnes" (v.23), orações cantadas e uma mistura de fé fatal e mágica, dada a condição das sereias “chansons pour les sirènes (v.25) - todas manifestações de lirismo, denotando que, mesmo trabalhando com rimas, sons e recursos poéticos, o "mal-aimé" ainda canta as dores do amor em uma poesia elegíaca.

Ao trabalharmos com esse subtema, analisamos o poema "Solau do Desamado" que segue tal linha, o qual, segundo o próprio Bandeira, foi inspirado em "La chanson du mal-aimé": 


\section{SOLAU DO DESAMADO}

Donzela, deixa tua aia, Tem pena de meu penar. Já das assomadas raia O clarão dilucular, E o meu olhar se desmaia Transido de te buscar. Sai desse ninho de alfaia, - Céu puro de teu sonhar, Veste o quimão de cambraia, Mostra-te ao fulgor lunar. Dá que uma só vez descaia Do ermo balcão do solar Como uma ardente azagaia $\mathrm{O}$ teu fuzilante olhar.

Donzela, deixa tua aia, Tem pena de meu penar...

Sou mancebo de alta laia: Não trabalho e sei justar. Relincham em minha baia Hacanéias de invejar. Tenho lacaio e lacaia. Como um boi ao meu jantar! Castelã donosa e gaia, Acode ao meu suspirar Antes que a luz se me esvaia... Tem pena de meu penar.

Vou-me ao golfo de Biscaia Como um bastardo afogar. Minh'alma blasfema e guaia, Minh'alma que vais danar, Dona Olaia, dona Olaia!

- Meu alaúde de faia, Soluça mais devagar...

Notamos já no título que o sujeito poético sofre do mal de amar : trata-se da figura do mal-amado, um protagonista desolado, desesperado por amar e não ser correspondido, apresentando um forte sentimento de pesar. Assim, a partir da estrutura dialógica e uma função apelativa com imperativos, vocativos e pronomes de $2^{\mathrm{a}}$ pessoa do discurso (a quem se fala), destacamos no poema dois personagens principais: a 
mulher, representada pela donzela e pela castelã, "castelã donosa e gaia" (v. 23), "Donzela, deixa tua aia," (v. 1), designada também pelos pronomes reflexivos "te", "Transido de te buscar" (v. 6), "Mostra-te ao fulgor do lunar" (v. 10) e ainda pelo pronome possessivo "teu", "Céu puro de teu sonhar" (v. 8); e o homem, amante representado pelo vocábulo "mancebo" e pela voz em primeira pessoa (a que fala): "Sou mancebo de alta laia:" (v. 17), "Não trabalho e sei justar" (v. 18), "Como um boi ao meu jantar!" (v. 22).

As personagens estão inseridas em uma esfera de ceticismo auto-arrasador, em que o amor dilacera o coração e mostra as conseqüências amargas que existem no ato de amar, provocando naquele que ama (mancebo) o sofrimento por não poder estar junto a sua amada (castelã/donzela) e a angústia por amar e não ser correspondido. Devemos salientar que notamos um outro tipo de angústia no poema banderiano, a saudade ontológica, "nostalgia do Ser, sentimento que se confunde com o puro tormento de estar no mundo, desgarrada a angústia existencial, imersão na intimidade profunda" (BRAYNER, 1980, p. 244). Dessa maneira, a questão da saudade ontológica explicita a angústia do sujeito-poético, representado sempre como mal-amado, no mundo que o cerca. Logo, o eu lírico sempre foi e será pesaroso, dada sua própria condição humana. Mesmo que viva uma relação amorosa, ela rapidamente se esvai, e ele retorna à sua condição primeira de mal-amado. Portanto, o sujeito poético vive perturbado ou angustiado em relação à sua existência, ao estar no mundo, visto que nunca se realizará enquanto ser humano, mas viverá sempre à mercê de sua problemática interior.

Notamos, então, que o poema banderiano se nutre de muitos aspectos medievais, pois segundo Huizinga, os grandes fermentos da cultura moderna estão na cultura medieval. E ainda segundo Ernst Robert Curtius, que diz: "A poesia do amor moderno é obra da Idade Média" (Cf. BRAYNER, 1980, p. 244-245)

Nesse sentido, partimos para mais uma tópica medieval na poesia de Manuel Bandeira: 


\section{A inacessibilidade da mulher amada}

Encontramos essa idéia em uma frase bastante característica na poética banderiana: “A vida inteira que podia ter sido e que não foi”. É dessa forma que Bandeira apresenta o eu poético "mal-amado", aquele que suplica o amor de sua amada e que sofre por não têlo: "Donzela, deixa tua aia", (v. 1); "Tem pena de meu penar" (v. 2); "E o meu olhar se desmaia" (v. 5); "Transido de te buscar" (v. 6). Nesses versos observamos tamanho sofrimento pela busca desse amor que o olhar do mancebo descora, desfalece, esmorece, demonstrando a sua luta para conquistá-lo, exigindo reconhecimento por tamanho esforço. Assim, vimos nos versos a existência do amor platônico, tal como ocorre na poesia trovadoresca, que se dirige a um objeto inatingível. É o tema do Bem Amado longínquo que orvalha de sonho e melancolia todo trovar dos líricos medievais (Cf. BRAYNER, 1980, p. 251).

Seguindo essa visão trovadoresca, o eu lírico banderiano insiste no convencimento de sua amada, "Sai desse ninho de alfaia", (v. 7); "Céu puro de teu sonhar," (v. 8); "Dá que uma só vez descaia" (v. 11); "Do ermo balcão do solar" (v. 12); "Como uma ardente azagaia" (v. 13); "O teu fuzilante olhar" (v. 14); "Donzela, deixa tua aia," (v. 15); "Tem pena de meu pensar..." (v. 16). Esses versos indicam o mundo pudico no qual sua donzela está inserida, em um ninho de ornato de igreja, em céu puro e na companhia de uma criada de dama nobre. Logo, pede-lhe que saia desse cosmo imaculado para que lhe dirija o seu fuzilante olhar ameaçador, questionando o seu caráter e a sua franqueza, e demonstrando que o sentimento do amor é enganador como a mulher. A partir do tema da inacessibilidade, trabalhamos com três tópicas da lírica trovadoresca que completam o esclarecimento da questão, a domnei - consagrando a submissão absoluta, a entrega total, humilde e paciente, a mesura - prudência, cuidado para que o amor não comprometa o prestígio social da Amada e a joy, a alegria suprema, estado de espírito que eleva o trovador acima de si mesmo (Cf. BRAYNER, 1980, p. 251). O sujeito poético utiliza-se dessas três tópicas pois eleva a sua amada acima dos céus, adorando-a com total submissão, e tendo cautela para não macular a sua moral, e ainda apresentando uma imensa alegria, que o coloca acima de si mesmo, pois ama tal donzela de forma sobrenatural, de forma beatificada. Essa inacessibilidade da mulher nos remete 
ao amor cortês, que também exprime total submissão do homem em relação à amada, sempre inatingível. Rosenbaum, neste sentido, (1993), que diz:

Historicamente, é na moral do amor cortês (séculos XI, XII e XIII) que Lacan identifica esse sistema literário que aborda o objeto feminino - a Dama - conferindo-lhe valor de representação da Coisa. O objeto feminino, aqui miragem da própria Coisa, corresponde a um primeiro plano do ideal, sendo sempre inatingível: “[...] o amor cortês era em suma um exercício poético, uma maneira de jogar com certo número de temas de convenção, idealizantes, que não podia ter nenhum correspondente concreto real". (p.129)

Mas não podemos esquecer que, se a própria Idade Média se opõe à Idade Média, as palavras de Tertuliano caracterizando a mulher em sua dialética como ianua diaboli são refutadas pela poética dos trovadores e mnnesaengers, para os quais a contemplação da Eleita substitui Deus: "Por que vos amo/tão finamente que não me lembro de mais nada,/nem mesmo quando rogo a Deus, do qual esqueço por amor de vós”. Assim observamos que, mesmo havendo uma beatificação do ser da mulher, notamos que ela aparece no poema de Bandeira e já na Idade Média de forma maniqueísta, com um lado bom, puro, casto e o outro lascivo e enganoso".(BRAYNER, 1980, p. 252).

Prosseguindo com a temática da inacessibilidade da mulher amada, notamos ainda outras tentativas de sedução do eu poético de "Solau do Desamado", com suas invectivas para impressionar a sua donzela. Assim, ele menciona a sua inserção social, a sua ociosidade, a capacidade de lutar esgrima, o fato de possuir cavalos, criados e a abundância de víveres, visto que não vê outra alternativa para conquistá-la: "Sou mancebo de alta laia:/Não trabalho e sei justar./Relincham em minha baia/Hacanéias de invejar./Tenho lacaio e lacaia./Como um boi ao meu jantar!", nos quais o amante lhe promete todos os seus bens(Cf. PONTIERO, 1986, p. 55). Mesmo assim, o tom terno e triste ainda perdura nos versos banderianos, vide os 27 a 31: "Vou-me ao golfo de Biscaia/Como um bastardo afogar./Minh'alma blasfema e guaia,/Minh'alma que vais danar,/Dona Olaia, dona Olaia!”, em que o poeta retoma o vigor das tradicionais formas portuguesas e extrai um pouco do humor malicioso que caracterizou tantas baladas desse gênero, visto que, no alvorecer do século $\mathrm{XX}$, há a reiteração de uma forma um 
tanto quanto arcaica, mas aqui estereotipada, como se ironizasse a sua própria condição de mal-amado.

Esses versos indicam a aflição que o eu lírico banderiano sente ao ameaçar com a tentativa de suicídio, demonstrando que prefere a morte à separação ou à rejeição de sua amada. Mas logo em seguida o refrão final nos assegura de que não há nada a temer, e que o trovador está em perfeito controle de sua situação (PONTIERO, 1986, p.55): “Meu alaúde de faia,/Soluça mais devagar..." (v. 32-33).

Portanto, vemos que as tópicas trabalhadas nos direcionam para o nosso tema de pesquisa, "Escritura da perda: um tempo não-reconciliado em Bandeira e Apollinaire", pois o sujeito poético deste poema padece por amar em demasia e sem reciprocidade, mostrando que a história vivida com sua amada não retorna em hipótese alguma. Logo, destacamos mais uma tópica que colaborou para o desenvolvimento do nosso tema:

\section{A musicalidade na poética banderiana}

Para uma maior compreensão do subtema proposto, analisamos a questão da musicalidade no poema "Solau do Desamado", que já no título, apresenta um eu poético angustiado e "mal-amado". Em seguida, observamos que o vocábulo solau significa um antigo romance em verso, geralmente acompanhado de música, que indica um gênero exclusivamente português e popular, talvez originário do latim solor-consolar, aliviar pelo canto, cantu solata (Virgílio, Geórgicas, I, 293). Em Bernardim Ribeiro, poeta português do século XVI, podemos identificar a expressão "Cantar à Maneira de Solau". O vocábulo "desamado" é forma substantivada do particípio do verbo desamar. Pode referir-se também à forma pronominal do verbo desmaiar, usada sobretudo literariamente e como arcaísmo, no caso significando perder o brilho, obscurecer (Moraes, 1986, p. 101). Assim, por meio dessas definições, destacamos a questão musical no poema, em que a figura do mal-amado busca o alívio de sua dor através do canto, mostrando um ser que perdeu o brilho, que obscureceu devido ao mal de amar. Ainda em relação à musicalidade poética, notamos que a própria disposição dos versos de "Solau do Desamado" nos remete ao subtema trabalhado, pois o poema de Bandeira, composto em versos de arte menor, alternados, com rimas em aia e ar, revive uma antiga forma de balada, comum na literatura do século XVI ao XVII, criando uma melodia própria, intrínseca ao poema. 
Nessa análise, observamos que Bandeira, talvez mais do que qualquer outro poeta brasileiro, se utilizou dos recursos musicais para realizar as suas criações poéticas:

A musicalidade da poesia de Bandeira não decorre da organização do poema, não emerge do processo de elaboração do poema, mas resulta da natureza intrínseca da emoção poética: música como que armada quase numa só equação de silêncio - tão fina se esconde na última camada audível da palavra; música que começa onde a palavra acaba. (BRAYNER, 1980, p. 237).

Dessa forma, podemos dizer que a musicalidade em Bandeira nos remete à definição do vocábulo elegia em sua origem, nome que parece ter sido dado primeiramente a uma espécie de lamento ou canto fúnebre acompanhado com som de flauta, havendo autores que ligam o étimo grego élegos a "sopro de flauta". O método específico chamava-se élegion, constando de hexâmetros, pentâmetros, dalíticos que se combinam em dísticos, por isso mesmo denominados elegíacos, e que no plural (èlegeía) constituíam o poema (MIRADOR INTERNACIONAL, 1975, p. 3693-3694).

Ao trabalharmos com nosso tema de pesquisa, a "escritura da perda", vimos que ele apresenta traços marcantes da poesia elegíaca grega, tanto na questão do subtema musicalidade (sopro de flauta) quanto na questão pesarosa do fazer poético (lamento ou canto fúnebre). Partimos então para a questão do símbolo na linguagem, pois, se a poesia era antigamente acompanhada ou composta pelo som de algum instrumento musical, na poesia moderna, como na poesia banderiana, encontram-se "lacunas" advindas da falta dessa prática. A musicalidade é trabalhada de uma outra forma: agora ela é inserida ou faz parte da própria composição dos versos. Se considerarmos a história da poesia, algumas considerações importantes podem ser lembradas, tal como a seguinte:

não esqueçamos [...] a gravidade da crise que afeta o lirismo a partir do século XIV. Até então o poema permanecia teoricamente tributário da música. $\mathrm{O}$ texto não era senão a face literária de uma obra feita para viver no embalo do canto. Mas enquanto a polifonia vem complicar a arte musical, a arte literária procura conquistar sua autonomia poética. Os poetas estão à procura de um novo lirismo que deveria se restringir unicamente à fala humana. Sobre as estruturas antigas é preciso então edificar uma obra nova, fundada doravante na magia da linguagem. Não é surpreendente que os primeiros monumentos deste lirismo 
moderno chamam a nossa atenção por uma certa insipidez e uma certa falta de elevação. É preciso esperar Charles D'Orléans para que a sutileza do estilo e a força das metáforas criem, nesse gênero novo, autênticas obras de arte. (POIRON, 1965, p. 11)

Mas não podemos esquecer que:

a acepção do vocábulo elegia não corresponde, de modo algum às primeiras elegias gregas, pois essas não passavam de canto de guerreiros, incitando à luta $\mathrm{e}$ também em relação à sua composição formal, por meio de hexâmetros, pentâmetros os quais se combinavam em dísticos. A elegia em sentido moderno, como na poesia de Bandeira, é sobretudo uma criação original da literatura latina. O primeiro grande nome é o de Tibulo, cujos três livros de elegias, comovidas e algo sentimentais, foram muito lidos na Idade Média e exerceram forte influência nos poetas da renascença. Foram preferidas as elegias de Propércio, dos elegíacos latinos Ovídio, cujos Tristia (Poemas tristes) e Epistolae ex Ponto (cantos do ponto), lamentando seu exílio, são os mais próximos da elegia moderna. (MIRADOR INTERNACIONAL, 1975, p. 3693-3694)

Desse modo, notamos, na origem do gênero elegíaco, uma forte tendência da poesia para a música, sempre sendo demasiadamente nostálgica e melancólica. Assim, vemos que esses traços originários do gênero perduram na poética banderiana, com uma poesia extremamente musical e pesarosa.

A seguir, destacamos os significados para alguns vocábulos do poema que colaboram para uma melhor compreensão. 
Vocabulário:

Solau: antigo romance em verso, geralmente acompanhado de música;

Aia: dama de companhia, criada de criança nobre, camareira;

Penar: sofrer pena, dor, aflição, pesar, tormento;

Assomadas: cumeada, cume, cabeço;

Dilucular: relativo ao crepúsculo (crepúsculo matutino, alvorada);

Transido: repassado de frio, medo;

Alfaia: tapeçarias, adornos, enfeites;

Quimão: quimono;

Azagaia: lança curta e fina usada como arma de arremesso;

Laia: casta, qualidade, feitio, espécie, raça, jaez;

Justar: ajustar, acertar, esgrimir, jogar;

Hacanéias: (do inglês hackney/francês haquenée) égua ou cavalo de forma delgada e elegante. Animal próprio para ser cavalgado pelas damas. Égua pequena e mansa.

Donosa: donairosa, elegante, graciosa, gentil;

Gaia: jovial, alegre;

Biscaia: $($ golfo de $)=$ ou da Gasconha = golfo do oceano Atlântico, entre a França e a Espanha;

Guaiar: soltar ais ou guais, queixar-se, lamentar-se;

Faia: nome comum de certas árvores de casca lisa, cinzenta e madeira dura de contextura fina;

Baia: compartimento ou espaço ao qual se recolhe o animal nas cavalariças e.estábulos. 


\section{Apollinaire e Bandeira}

Podemos dizer que ao compararmos os dois poemas sob o viés do medievalismo, encontramos, de forma semelhante, já em seus títulos, o sujeito poético que sofre do mal de amar, "mal-aimé" em Apollinaire e "desamado" em Bandeira. Desse modo, observamos nos títulos uma antecipação dos acontecimentos passados nos poemas, o que já define seus protagonistas como desolados, desesperados por amar e não serem correspondidos, apresentando um forte sentimento de pesar.

Assim, é possível progredir com a análise propriamente dita dos poemas, que de forma semelhante abordam a questão do fim de amor, e ainda apresentam duas personagens principais, como em Bandeira por meio de uma estrutura dialógica e uma função apelativa com imperativos, vocativos e pronomes da segunda pessoa do discurso (a quem se fala), a mulher, representada pela donzela e pela Castelã, e o homem, amante representado pelo pelo vocábulo "mancebo". De modo semelhante, a partir de uma história de amor finda, observamos, também em Apollinaire, duas personagens principais, o homem que diz "je" (aquele que fala), identificado somente como "MalAimé" do título, a mulher que foi "bien aimée" (v. 12), que aparece primeiro como "tu" (a quem se fala) no discurso do Mal-Aimé (monólogo interior da estrofe 3) e em seguida é designada, em terceira pessoa, pelo pronome lui (de quem se fala): "Une femme lui ressemblant" (v. 22).

Além da semelhança de ordem estrutural dos poemas, notamos ainda que eles foram inscritos em um cosmo demasiadamente nostálgico no qual o amor mortifica o coração daqueles que amam. Notamos que as personagens estão inseridas em uma esfera de ceticismo auto-arrasador, em que o amor dilacera o coração e monstra as consequências amargas que existem no ato de amar, provocando naquele que ama (mancebo) e (mal-aimé) o sofrimento por não poder estar junto a sua amada (castelã/ Donzela) e (bien-aimée).

A concepção de amor medieval presente em ambos os poemas, mostra, seja pela busca do amor perdido, em Apollinaire, seja pelas súplicas de amor e ameaças de suicídio em Bandeira, todo o pesar e a efemeridade que existem no ato de amar. Com essa concepção, notamos que nos dois poemas há um fundo notadamente negativo, como na Idade Média pois, então, a morte inevitável certificava o homem de que "toda beleza e toda felicidade (amor) eram inúteis porque estavam destinados a acabar em breve". 
(HUIZINGA, 1978, p. 131) - processo que ocorreu tanto com o eu-lírico bandeiriano quanto o apollinairiano, pois ambos sempre foram e serão pesarosos, dada a sua condição humana, mesmo ao viverem uma relação amorosa, ela rapidamente acabará, fazendo com que eles retornem à condição primeira de "mal-aimé"e "desamado".

Embora tenhamos constatado tais similitudes, vimos que Apollinaire se utiliza de traços humorísticos em seu poema, dignos de uma composição moderna, como na estrofe 40: "Et moi j'ai le coeur aussi gross", "Qu'un cul de dorme damascène", mesclando o passado com o presente, com vocábulos dos mais raros até os mais triviais, o que em Bandeira não ocorre, porque ele usou um vocabulário um tanto quanto formal e que nos direciona para uma leitura medieval, apesar de ter sido escrito no século XX.

Por fim, observamos que os poemas bandeiriano e apollinairiano se nutriram de muitos aspectos medievais pois, "segundo Huizinga, os grandes fermentos da cultura moderna estão na cultura medieval. E ainda de acordo com Robert Curtius que diz: "A poesia do amor moderno é obra da Idade Média"(BRAYNER, 1980, p. 244-245)

Nesse sentido, desenvolvemos mais uma tópica medieval na poesia de Manuel Bandeira e Guillaume Apollinaire:

\section{A inacessibilidade da mulher amada - "santidade"}

Por meio dessa tópica, notamos que nos poemas "Solau do Desamado" e "La Chanson du Mal-Aimé", "há a presença da aura das coisas inatingíveis. A vida autêntica -mas longínqua- no tempo e no espaço" (BRAYNER, 1980, p. 244) - o que coloca o sujeito poético de tais poemas longe de sua amada, confirmando a sua condição única e primeira de "mal-aimé" e "desamado". É dessa forma que Bandeira apresenta o eupoético "desamado", aquele que suplica o amor de sua amada e que sofre por não tê-lo.

O mesmo ocorre no poema de Apollinaire, a angústia pelo fato do eu-lírico não possuir o seu grande amor, o que é observado na estrofe 55, na qual o episódio do poema se encontra situado no tempo "juin" (v. 1) e no espaço "Paris" (v. 4), mostra que tal história de amor se localiza apenas no passado. Nessa estrofe os "doigts indoloris", (v.2) evocam por associação de idéias o coração dilacerado do jovem, no qual o imenso desespero amoroso foi cantado nas cinqüenta e quatro estrofes precedentes.

Nesse viés, destacamos ainda mais uma semelhança nos poemas: o desespero do eu-lírico bandeiriano e apollinairiano em face da inacessibilidade de sua amada, ao 
ameaçarem tentativa de suicídio, indicando que preferem a morte à separação ou rejeição de sua amada . Em seguida o refrão final em Bandeira nos assegura de que não há nada a temer, e que o trovador está em perfeito controle de sua situação, fato que se manifesta da mesma forma em Apollinaire, pois na estrofe 55, o vocábulo "triste", que qualifica "délire" (v. 3), "Triste et mélodieux délire", mostra que a crise psicológica e moral se resolve por ela mesma, e que a tentativa de suicídio não chega ao fim, como confirma o verso 5: "Sans avoir le coeur d'y mourir". Sendo assim, constatamos que a figura do mal-aimé e do "desamado", nos dois poemas, acabam por aceitar essa condição de seres abandonados, visto que não podem mudá-la.

Portanto, nessa análise, vimos que a tópica trabalhada nos leva ao nosso tema de pesquisa, "Escritura da perda: um tempo não-reconciliado em Bandeira e Apollinaire", pois o sujeito poético dos poemas trabalhados padece por amar em demasia e sem reciprocidade, resultado de um tempo sempre não-reconciliado.

\section{A musicalidade na poética bandeiriana e apollinairiana}

Ao estudarmos essa tópica, observamos que tanto "Solau do Desamado"quanto "La Chanson du Mal-Aimé" são poemas musicados, que cantam todo o pesar da figura do mal amado. Salientamos que o vocábulo "solau" de Bandeira significa antigo romance em verso geralmente acompanhado de música, o que indica um gênero exclusivamente português e popular, talvez originário do latim "solar-consolar", aliviar pelo canto, “cantu solata”. Em Bernardino Ribeiro, poeta português do século XVI, podemos identificar a expressão "Cantar à Maneira de Solau". É nesse sentido e por meio dessas definições em que destacamos a questão musical no poema, em que a figura do "desamado" busca o alívio para sua dor, daquele que não é amado, através do canto, mostrando-se um ser que perdeu o brilho, que obscureceu devido ao mal de amar. Ainda em relação à musicalidade poética, notamos que a própria disposição dos versos de "Solau do Desamado" nos remete ao subtema trabalhado, pois o poema de Bandeira é composto em versos de arte menor, alternados, com rimas em aia e ar, revivendo uma antiga forma de balada, muito comum na literatura dos séculos XVI ao XVII, criando uma melodia própria, intrínseca ao poema.

Esse traço de musicalidade também é percebido em "La Chanson du Mal-Aimé", poema identificado como uma canção amorosa, cheia de lamentos, que transforma a 
tristeza em canto. Nas duas últimas estrofes 58 e 59, trabalhamos os aspectos mais importantes relacionados ao amor elegíaco, como os diversos barulhos que se escutam nessa cidade, como palco das angústias do mal-aimé, cujo mais notável é um grito indiferente de amor (provado pelos "tziganes", os "siphons", "os garçons") lançado pelos “cafés"(v. 16), lugar onde se misturam todos esses sons que se encontram personificados.

Podemos dizer que a musicalidade em Bandeira e em Apollinaire nos leva à definição do vocábulo elegia em sua origem, nome que parece ter sido dado primeiramente a uma espécie de lamento ou canto fúnebre acompanhado com o som de flauta, havendo autores que ligam o étimo grego élegos a "sopro de flauta". Nesse sentido, ao trabalharmos com o nosso tema de pesquisa, "escritura da perda", vemos que apresenta traços marcantes da poesia alegíaca grega, tanto na questão do subtema musicalidade (sopro de flauta) quanto na questão pesarosa do fazer poético (lamento ou canto fúnebre).

É, pois, de suma importância salientar que o poema francês apresenta 295 versos, diversas histórias que denunciam a fragilidade do amor, e ainda uma linguagem moderna com traços humorísticos. Dessa maneira, vimos nitidamente um confronto produtivo com o Outro - "La Chanson du Mal-Aimé"/"Solau do Desamado" - uma absorção e transformação do poema francês, visto que a diferença se dá no fato de o segundo ser constituído por 33 versos, uma mudança significativa, além de apresentar somente uma história de amor findo, e uma linguagem oposta à moderna, a medieval.

Em resumo, notamos que a origem do gênero elegíaco está ligada à música, esta última sendo demasiadamente nostálgica e melancólica. Assim, vemos que esses traços originários do gênero perduram nas poéticas bandeiriana e apollinairiana, por meio de uma poesia extremamente musical e pesarosa. 


\section{2 - 0 noturno como marca de uma poesia penumbrista}

Dando sequiência à análise com a temática do noturno, temos dois poemas cuja ambientação se dá na escuridão da noite e de seus mistérios, "Le vent nocturne" e "Madrugada". Desse modo, analisamos primeiramente "Le vent nocturne", que retrata a melancolia penumbrista existente na poesia pesarosa em questão:

Le vent nocturne

Oh! Les cimes des pins grincent em se heurtant

Et l'on entend aussi se lamenter l'autan

Et du fleuve prochain à grand'voix triomphales

Les elfes rire au vent ou corner aux rafales

Attys Attys Attys Charmant et débraillé

C'est ton nom qu'en la nuit les elfes ont raillé

Parce qu'un de tes pins s'abat au vent gothique

La forêt fuit au loin comme une armée antique

Dont les lances ô pins s'agint au tournant

Les villages éteints méditent maintenant

Comme les vierges les vieillards et les poètes

Et ne s'éveilleront au pas de nul venant

$\mathrm{Ni}$ quand sur leurs pigeons fondront les gypaètes

Demos início à análise com o poema de Apollinaire, no qual notamos uma atmosfera assaz melancólica em que se escuta o lamento do vento sul, ainda o ranger dos cumes dos pinheiros se chocando e a interjeição "Oh" (V.1), da qual emana, de antemão, um grande pesar como abertura do poema: "Oh! Les cimes des pins grincent en se heurtent", "Et l'on entend se lamenter l'autan" (V.1e 2).

Temos nos versos seguintes um rio próximo de onde se escuta, com voz triunfal, os diversos barulhos desordenados dos gênios do ar, na mitologia escandinava "elfes", que com toda a sua fúria das rajadas ou vendavais ("rafales") apresentam uma frase direcionada para uma segunda pessoa, quiçá a mulher amada do sujeito poético em questão: "Et du fleuve prochain à grand'voix triomphales", "Les elfes rire au vent au 
corner aux rafales”, “Attys Attys Attys charmant et débraillé”, "C'est ton nom qu'un la nuit les elfes ont raillé" (V.3,4,5 e 6). É importante destacar, que diante desse cenário obscuro, apesar da ambientação elegíaca, há a presença de uma certa ironia no poema, pois os "elfes", gênios do ar, zombam e brincam com o nome daquela a quem o eu lírico se dirige, talvez devido a uma história de amor finda, como tentativa de vingança por parte desse mal-amado.

Logo, devemos mencionar um fato que contribuiu sobremaneira para o estudo desse poema: a sua inserção no "Groupe des Rhénanes", pois nesse observamos as primeiras impressões de Apollinaire evocadas diante do ambiente em que viveu durante um ano, na Alemanha, na casa dos Milhau. Esse, como outros poemas do ciclo renano, apresentam explicitamente ou implicita a paixão do jovem poeta pela governanta da casa onde trabalhou, Annie Playden, um de seus grandes amores findos. Dessa forma, podemos inferir que, longe de uma leitura puramente biográfica, essa segunda pessoa a quem o sujeito poético se direciona, no verso 6, seria Annie Playden em meio a toda a atmosfera natural, com as árvores e o rio Reno, a paisagem germânica.

Ademais, vimos que o vento noturno é classificado como "vento gótico", direcionando-nos para uma cultura obscura, devido ao período sombrio mencionado, o penumbrista dos godos, mostrando toda a sua fúria por meio da queda de um dos pinheiros do cenário. Ainda, essa ambientação é constituída por uma floresta que se mostra fugidia e longínqua na noite, como um batalhão antigo, cujas lanças, os cumes dos pinheiros, agitam-se com movimentos circulares: "Parce qu'un de tes pins s'abat au vent gothique", "La forêt fuit au loin comme une armée antique", "Dont les lances ô pins s'agitent au tourment" (V.7,8 e 9).

Nesse viés, vimos que, em tal atmosfera de trevas, o sujeito poético apresenta as cidades dormindo, mas meditando ao mesmo tempo, como metáfora da vigília angustiante daqueles que pensam em seus amores, seus medos e seus desejos secretos, confirmando a citação de Shakespeare em Hamlet: "Alguns devem velar, enquanto outros devem dormir"/ "Assim gira o mundo". É o que ocorre com as virgens que sonham acordadas com toda a sua ansiedade inocente, os velhos que naturalmente reduzem o tempo de sono, e conseqüentemente velam toda a nostalgia de um passado e o temor de um futuro não muito longo, e os poetas que, mesmo nas horas mais mortas do dia, a noite, transformam e despertam o sentimento do belo: "Les villages éteints méditent maintenant", "Comme les vierges les vieillards et les poètes" (V.10 e 11). 
Notamos que no final do poema há a permanência do eu lírico mal-amado no cenário sombrio, pois indica que "as virgens, os velhos e os poetas", incluindo ele, não acordarão em hipótese alguma, nem mesmo quando os pombos forem abatidos pelas grandes aves de rapina, que caçam durante o dia. Essas são apresentadas como símbolo do dia, visto que não fazem suas buscas à noite . Desse modo, mesmo que tais aves cheguem para anunciar a luz, o sujeito poético insiste em permanecer nas trevas, como forma de reviver os sentimentos findos, pois à noite tudo é possível, e o que é reprimido pela moral da claridade do dia, na escuridão se faz viável: "Et ne s'éveilleront au pas de nul venant", "Ni quand sur leurs pigeons fondront les gypaètes" (V.12 e 13)

Em resumo, "Le Vent Nocturne" se inscreve em um cenário obscuro e solitário, caracterizando o pesar do eu lírico mal-amado por meio de medos da realidade diurna ou dos mistérios noturnos, de amores não correspondidos e de sentimentos escondidos no manto negro da noite.

Dando continuidade ao estudo da temática do noturno, partimos para a análise do poema de Bandeira "Madrugada", que elege como panorama a madrugada fria onde tudo dorme.

Madrugada

As estrelas tremem no ar frio, no céu frio...

E no ar frio pinga, levíssima, a orvalhada.

Nem mais um ruído corta o silêncio da estrada,

Senão na ribanceira um vago murmúrio.

Tudo dorme. Eu, no entanto, olho o espaço sombrio,

Pensando em ti, ó doce imagem adorada!...

As estrelas tremem no ar frio, no céu frio,

E no ar frio pingam as gotas da orvalhada...

E enquanto penso em ti, no meu sonho erradio,

Sentindo a dor atroz desta ânsia incontentada,

- Fora, os beijos glaciais e cruéis da geada,

Tremem as flores, treme e foge, ondeando, o rio,

E as estrelas tremem no ar frio, no céu frio. 
Observamos que a primeira estrofe apresenta um céu frio em que até mesmo as estrelas tremem, gotículas da orvalhada que se condensam nas superfícies frias e um silêncio pavoroso interrompido apenas por um vago murmúrio na ribanceira: "As estrelas tremem no ar frio, no céu frio...", "E no ar frio pinga, levíssima, a orvalhada.", “ Nem mais um ruído corta o silêncio da estrada," "Se não na ribanceira um vago murmúrio." (V.1,2,3 e 4)

$\mathrm{Na}$ estrofe seguinte, temos a certeza de que na madrugada fria tudo dorme, exceto o sujeito poético mal-amado que na vigília olha o espaço sombrio, pensando na imagem adorada de sua amada, confirmando a sua solidão em meio ao negrume da noite: “ Tudo dorme. Eu, no entanto, olho o espaço sombrio,", "Pensando em ti, ó doce imagem adorada!..." (V.5 e 6). Nessa, as estrelas continuam a tremer no ar e céu frios, com as gotas da orvalhada a pingar, como em um cenário gélido e assustador, pois até mesmo os astros com luz própria, que poderiam trazer claridade à escuridão, tremem e se apagam diante de tamanha força das trevas: "As estrelas tremem no ar frio, no céu frio,", "E no ar frio pingam as gotas da orvalhada..." (V.7 e 8).

$\mathrm{Na}$ terceira estrofe, o eu lírico insiste em dizer que pensa em sua amada, e chega a se perder em seu sonho ou pensamento. Dessa forma, já não sabemos se o eu-poético está sonhando, ou se está simplesmente sonhando acordado: "Enquanto penso em ti, no meu sonho erradio,". Diante dessa atmosfera que emana melancolia, onde tudo parece tremer com o frio da madrugada, vimos que a arte do fazer poético se mistura ao sonho, sendo esse um mundo de fantasia.A figura do mal-amado aí se refugia para tentar reviver a lembrança daquela imagem adorada que se esvaeceu com o tempo, pois é na arte que os sonhos e a imaginação se cruzam:

mas os sonhos não são simplesmente um mundo de fantasia para onde o artista foge; são também parte da natureza e da trama da arte. Em outras palavras, é na arte que os sonhos e a imaginação se cruzam e, muito antes de os românticos redescobrirem o pesadelo e Freud o inconsciente, a função da arte era de alimentar a realidade desperta com o poder, a vividez e a dramaticidade dos sonhos. (ALVAREZ, 1996, p.164) 
Nos versos subseqüentes, o pesar do eu lírico toma maior força e clareza, visto que o pensamento na imagem adorada provoca uma dor intolerável como resultado da ânsia incontentada: "Sentindo a dor atroz desta ânsia incontentada," (V.10). Essa consternação é confirmada por meio de beijos glaciais e cruéis da geada, o que nos causa um certo estranhamento, pois o calor e o júbilo que tal atitude amorosa deveria provocar, são aqui apresentados com crueldade e gelidez. Nesse cenário congelado pelo frio da madrugada, as flores tremem e o rio foge movendo-se em ondulações, a natureza é então cúmplice de tal estado pesaroso: “- Fora, aos beijos glaciais e cruéis da geada", “Tremem as flores, treme e foge, ondeando, o rio," (V.11 e 12).

"Madrugada" termina com a repetição do verso "E as estrelas tremem no ar frio, no céu frio..." (V.13), que intensifica a permanência do eu-poético pesaroso na escuridão da noite, garantida pelas reticências, na medida que é nessa ambientação, característica de todo o seu lamento, que pode reviver o que findou.

Enfim, "Madrugada" elege como palco a noite fria, com toda a sua carga simbólica de lamento, solidão e enigmas, sendo propícia para reanimar ou reviver na figura do mal-amado aquilo que o tempo levou consigo. 


\section{Apollinaire e Bandeira}

Dando sequiência, iniciamos o diálogo entre as duas poéticas, elegendo como fio condutor a escuridão da noite, cuja análise se passa no universo da ausência do sol.

Então, nota-se que tanto "Le vent nocturne" quanto "Madrugada" têm a escuridão como cenário de uma poesia penumbrista. Logo, considerando toda a simbologia existente nessa atmosfera, citamos a visão dos gregos que colaborou de forma relevante para o estudo dessa temática obscura e elegíaca. Nessa, a noite (nyx) era a filha de Caos e a mãe do Céu (Urano) e da Terra (Gaia). Ainda produziu o sono e a morte, os sonhos e as angústias, a ternura e o engano. É o que observamos nos poemas, pois o eu lírico nos leva a um mundo de mistério e consternação, o qual não conseguimos identificar se é a vigília ou o sono onde o inconsciente se libera, o berço frio e a escuridão da morte, ou a ternura vindoura do desabrochar do dia seguinte.

Nesse cenário de trevas e incertezas, a melancolia no poema "Le vent nocturne" se manifesta por meio do lamento do vento sul, do ranger dos cumes dos pinheiros se chocando e da interjeição “Oh!”(V.1), da qual emana por antecipação um grande pesar: "Oh! Les cimes des pins grincent em se heurtent”, “Et l'on entend se lamenter l'autan" (V.1e 2).

De forma semelhante, "Madrugada" se inscreve em uma atmosfera repleta de sombriedade e de enigmas, tendo também a angústia como sentimento constitutivo do poema, cuja ambientação se constrói por meio de um céu frio em que até mesmo as estrelas tremem. Assim, como "Le vent nocturne", todos dormem e o silêncio noturno paira no ar, sendo interrompido apenas por um vago murmúrio na ribanceira: "As estrelas tremem no ar frio, no céu frio...”, "E no ar frio pinga, levíssima, a orvalhada.”, “ Nem mais um ruído corta o silêncio da estrada," "Se não na ribanceira um vago murmúrio." (V.1,2,3 e 4). Logo, notamos cenários frios, obscuros, solitários e enigmáticos, como a própria historicidade da temática da noite nos apresenta, pois, segundo Bruce Chatwin, a razão para que o mal esteja sempre associado à escuridão na mente humana tem suas raízes nos homens primitivos que acreditavam, além de todos os símbolos, nictomórficos de vulnerabilidade, solidão e frio que as trevas possuíam um predador maligno que apreciava a carne humana, chamado Dinofélis: 
Dinofélis era um felino menos ágil do que um leopardo ou uma chita, mas muito mais encorpado. Seus dentes mortíferos eram retilíneos como adagas, a meio caminho em sua forma entre os de um dente-de-sabre e os de um tigre atual. Sua mandíbula inferior podia fechar-se com violência e, como devido à sua constituição física algo pesado ele precisava caçar de emboscada, deve também ter caçado à noite [...] seus ossos foram encontrados do Transvaal à Etiópia: ou seja, a área de presença original do homem. (...) Será que somos tentados a perguntar, que o Dinofélis era a Nossa Besta, uma Besta separada de todos os outros Avatares do Inferno? O Arquiinimigo que nos espreitava, dissimulada e astuciosamente, onde quer que fôssemos? Quer aceitemos um grande felino, vários felinos ou horrores como a hiena caçadora, o que Bob Brain conseguiu, na minha opinião foi recuperar uma figura cuja presença vinha se tornando cada vez mais obscura desde o fim da Idade Média: o Príncipe das trevas em toda a sua sinistra magnificência. (ÁLVARES, 1996, p.47-48)

É nesse viés que se inscrevem tais poemas, tendo o cenário noturno, com toda sua carga simbólica de terrores e solitude, como condição primeira para nutrir tanto o eu lírico mal-amado por natureza bandeiriano, quanto o apollinairiano, visto que suas poesias são insistentemente pesarosas e obscuras em praticamente toda as obras aqui estudadas.

Nos versos seguintes de "Le vent nocturne", notamos um rio próximo de onde se escuta, com voz triunfal, os diversos barulhos desordenados dos gênios do ar, na mitologia escandinava "elfes", que com toda a fúria das rajadas ou vendavais ("rafales") apresentam uma frase direcionada para uma segunda pessoa, quiçá a mulher amada do sujeito poético em questão: "Et du fleuve prochain à grand voix triomphales", "Les elfes rire au vent au córner aux rafales", "Attys, Attys, Attys charmant et débraillé", "C'est ton nom qu'em la nuit lês elfes ont raillé"(V.3,4,5 e 6). Com esses, devemos nos reportar ao que Silvana Amorim, em seu livro Guillaume Apollinaire: fábula e lírica, estuda: a questão fabulírica dos poemas do Ciclo Rhénanes. E o que observamos em "Le vent nocturne": há um cruzamento de sonho e realidade, lenda e cotidiano, e ainda a presença do sobrenatural manifestada de várias formas, como exemplo, o mito dos "elfes". Assim, podemos dizer que todos os aparatos fabulares e mitológicos presentes na obra de Apollinaire nos levam para uma evasão simbolista, sendo as lembranças esmaecidas pela passagem do tempo, resgatadas em uma poesia calcada no onírico onde se pode reviver ou recriar o que findou. Essa poesia com incursões no onírico, pode ser ainda 
exemplificada pela própria atmosfera que a constitui, pois, estando o poema localizado na noite, nunca temos a certeza de que tudo não passa realmente de um sonho.

Do mesmo modo que Apollinaire, Manuel Bandeira aborda na segunda estrofe a questão da madrugada fria em que todos dormem, exceto o eu lírico mal-amado que na vigília olha o espaço sombrio pensando na doce imagem adorada de sua amada, confirmando a sua solidão em meio ao negrume da noite: "Tudo dorme. Eu, no entanto, olho o espaço sombrio", "Pensando em ti, ó doce imagem adorada!..." (V.5 e 6). Nessa, as estrelas continuam a tremer no ar e céus frios, com as gotas da orvalhada a pingar, como em um cenário gélido e assustador, pois até mesmo os astros com luz própria, que poderiam trazer claridade a essa escuridão, tremem e se apagam diante de tamanha força das trevas: "As estrelas tremem no ar frio, no céu frio,", "E no ar frio pingam as gotas da orvalhada..."(V.7 e 8). Logo, de forma semelhante a "Le vent nocturne", aqui o frio e o vento da madrugada corroboram a imagem lúgubre do ambiente no qual se insere o eu lírico pesaroso, atestando o caráter melancólico da obra estudada, A cinza das horas, que é escrita com "a cinza fria que restou das horas ardentes", e também, Alcools, com "as cinzas" que ficaram do fogo que transforma a bebida que queima e embriaga.

Desse modo, vimos que tanto Bandeira quanto Apollinaire citam diretamente ou indiretamente a imagem da mulher amada na noite fria, o que nos direciona para um fator importante da vida do primeiro cujos muitos exegetas pouco analisaram, tendo Ivan Junqueira abordado de forma significativa. O crítico, em seu livro Manuel Bandeira Testamento de Pasárgada aponta o fato de o poeta ter sido um homem doente e de vida social extremamente irregular. Além disso, nunca pôde contar com os atributos de beleza física que a vida, ainda uma vez madrasta, negou-lhe. Suas relações amorosas com as mulheres foram, por isso mesmo, sempre problemáticas e, não raro, frustrantes. (JUNQUEIRA, 2003,p.209). Assim, a doce imagem adorada para quem o eu lírico se direciona pode ser a lembrança de um amor acabado, tendo uma relação bastante próxima à de Apollinaire, na medida em que o poeta francês também teve várias histórias de amor cessadas.

Um outro dado relevante para a nossa pesquisa é a possível explicação para a presença enfática do cenário noturno na poética Bandeiriana, que provavelmente tem ligação com o seu estado de homem tísico, cujo tratamento foi cheio de imposições de repouso e confinamentos. Dessa maneira, Bandeira se viu em um mundo de silêncio e solidão, tendo a noite e a morte como fiéis companheiras durante toda a sua vida. Mas o 
mais interessante é que, o poeta deveria, de acordo com as orientações médicas, sair durante a manhã ou à tarde, mas fazia o contrário, pois era completamente da noite, mesmo porque a luz do sol é que lhe desencadeava as piores crises, talvez por sofrer também de um agudo processo alérgico. Logo, o silêncio e a solidão da noite estão em grande parte de seus poemas, com todas as suas sombras e fantasmagorias (JUNQUEIRA, 2003, p.233). É importante ressaltar que tais referências biográficas não reduzem a grandeza da poética bandeiriana simplesmente à sua vida, mas colaboram para compreender ainda mais a grandiosidade de sua incomparável lírica.

Vimos ainda que em "Le vent nocturne" o vento é classificado como vento gótico, direcionando-nos para uma cultura obscura, devido ao período sombrio mencionado, de estilo penumbrista dos godos. Observa-se, então, que em tal atmosfera de trevas, o sujeito poético apresenta as cidades dormindo, mas meditando ao mesmo tempo, como metáfora da vigília angustiante daqueles que pensam em seus amores, seus medos e seus desejos secretos. "É o que ocorre com as virgens que sonham acordadas com toda a sua ansiedade inocente, os velhos que naturalmente reduzem o tempo de sono, e conseqüentemente velam com nostalgia todo um passado e o temor de um futuro, e os poetas que, mesmo nas horas mais mortas do dia, à noite, transformam e despertam o sentimento do belo: "Les villages éteins méditent maintenant", "Comme les vierges les vieillards et les poètes" (V.10 e 11). Mas devemos mencionar que, apesar de essas personagens se mostrarem acordadas, não temos certeza de tal situação, nada nos garante que elas estejam dormindo com o restante da cidade, pois todo o cenário, com os gênios do ar e a floresta personificada em um batalhão, já nos demonstra uma atmosfera onírica, sem a lógica do mundo da vigília, o que Eugène Ionesco vê como, o sonhar sendo a base da arte:

O sonho é puro drama. Num sonho, a pessoa está sempre numa situação intermediária. Para ser mais conciso, creio que o sonho é um pensamento lúcido, mais lúcido do que qualquer pessoa tem quando está acordada, um pensamento expresso em imagens, e que, além disso, sua forma é sempre dramatizada (EUGÈNE IONESCO Apud ALVAREZ, 1996, p.144)

O mesmo acontece na terceira estrofe de "Madrugada", o eu-lírico insiste em dizer que pensa em sua amada, e chega a se perder em seu sonho ou pensamento. Dessa 
forma, já não sabemos se está sonhando, ou se está simplesmente sonhando acordado: "E enquanto penso em ti, no meu sonho erradio," (V.9). Logo, diante dessa atmosfera sombria e melancólica, onde tudo parece dormir e tremer no frio da madrugada, vimos que a arte se mistura ao sonho, sendo esse um mundo de fantasia. A figura do malamado aí se refugia, como em "Le vent nocturne", para tentar reviver a lembrança daquela imagem adorada que se esvaeceu com o tempo, pois é na arte que os sonhos e a imaginação se cruzam:

mas os sonhos não são simplesmente um mundo de fantasia para onde o artista foge; são também parte da natureza e da trama da arte. Em outras palavras, é na arte que os sonhos e a imaginação se cruzam e muito antes dos românticos redescobrirem o pesadelo e de Freud o inconsciente, a função da arte e a dramaticidade dos sonhos. (ALVAREZ, 1996, p.164)

Essa consternação, ao mesmo tempo feérica, é confirmada por meio da paisagem acrescida de beijos glaciais e cruéis da geada, o que nos causa um certo estranhamento, primeiro porque a geada está personificada, segundo porque o calor e o júbilo que tal atitude amorosa deveria provocar é aqui apresentada com crueldade e gelidez. Diante desse cenário congelado pelo frio da madrugada, as flores tremem e o rio foge, movendo-se em ondulações: "Fora, aos beijos glaciais e cruéis da geada", "Tremem as flores, treme e foge, ondeando, o rio," (V.11 e 12).

Ademais, vimos que, tanto em "Madrugada quanto em "Le vent nocturne", há a presença de um rio, o que nos chama a atenção para o seu caráter simbólico de fertilidade, morte e renovação. Esse simboliza ainda a existência humana e o curso da vida, pois a variedade de seus desvios indica tanto o nascimento em uma nascente quanto o morrer nas águas do oceano. Logo, podemos inferir que as águas que escoam são metáfora da passagem do tempo nos poemas, indicando a lembrança da mulher amada como algo que se perdeu no olvido imenso do passado.

Notamos que no final de "Le vent nocturne" há a permanência do eu lírico malamado no cenário sombrio, pois esse indica que “ as virgens, os velhos e os poetas", incluindo ele, não acordarão em hipótese alguma, nem mesmo quando os pombos forem abatidos pelas grandes aves de rapina, que caçam somente durante o dia. Elas são apresentadas como símbolos do dia, visto que não fazem suas buscas à noite. Desse 
modo, mesmo que tais pássaros cheguem para anunciar o dia, o sujeito poético insiste em permanecer nas trevas: "Et ne s'éveilleront au pas de nul venant", "Ni quand sur leurs pigeons fondront les gypaètes" (V.12 e 13).

É o que ocorre em "Madrugada", encerrando com a repetição do verso 7, e intensificando a permanência do eu poético pesaroso na escuridão da noite, garantida ainda pelas reticências, na medida em que é nessa ambientação, característica de todo o seu lamento, que se pode reviver o que se esvaeceu com o decurso do tempo: "E as estrelas tremem no ar frio, no céu frio"... (V.13).

Por fim, "Madrugada" e "Le vent nocturne" são poemas que se constituem sob o manto obscuro da noite e do lirismo triste, com todos os seus sortilégios e terrores, sendo campo de liberdade para o eu lírico, por meio do fazer poético, recuperar o que os crepúsculos diários levaram consigo e que não se pode reviver na claridade do dia. 


\subsection{A efemeridade do amor e a inexorabilidade do tempo}

Dando continuidade ao tema de nossa pesquisa, "Escritura da perda: um tempo não-reconciliado em Bandeira e Apollinaire", analisamos ainda o pesar na figura do “mal-aimé” no poema “Le Pont Mirabeau”(1912):

Le pont Mirabeau

Sous le pont Mirabeau coule la Seine

Et nos amours

Faut-il qu'il m'en souvienne

La joie venait toujours après la peine.

Vienne la nuit sonne l'heure

Les jours s'en vont je demeure

Les mains dans les mains restons face à face

Tandis que sous

Le pont de nos bras passe

Des éternels regards l'onde si lasse

Vienne la nuit sonne l'heure

Les jours s'en vont je demeure

L'amour s'en va comme cette eau courante

L'amour s'en va

Comme la vie est lente

Et comme l'Espérance est violente

Vienne la nuit sonne l'heure

Les jours s'en vont je demeure 
Passent les jours et passent les semaines

Ni temps passé

$\mathrm{Ni}$ les amours reviennent

Sous le pont Mirabeau coule la Seine

Vienne la nuit sonne l'heure

Les jours s'en vont je demeure

Ao trabalharmos com este subtema no poema selecionado, vimos que ele nos apresenta um cosmo de tamanha melancolia que o término do amor se equipara ao desespero do olhar daquele que não pode reter o tempo que passa. Desse modo, o eu lírico apresenta a angústia pelo tempo ininterrupto que leva embora os amores e o faz se distanciar de seus anos de gozo.O sujeito poético sofre ao se indagar a respeito de que forma pode esquecer ou aceitar a passagem dos anos e de seus amores. Essa angústia pode ser suprimida na tentativa de se criar um novo mundo, imaginário, no qual seus alcools amenizam o desespero advindo da efermidade do amor e da passagem de todas as coisas terrenas. Nesse mundo onde não existe pesar, quiçá um "au-delà" baudelairiano, em que a evasão fictícia colabora para que as agruras vivenciadas sejam mais leves e mais fáceis, o eu-lírico de uma certa forma obtém um consolo:

Comment oublier les années et les amours qui passent, résistir au lent empoisonnement du temps? Première tentative: l"imagination et ses alcools semblent nous ouvrir un monde où tout est plus léger, plus facile. (LECHERBONNIER, 1993, p.15)

Embora haja uma embriaguez poética como fuga da amarga realidade, o sujeito poético não alcança êxito, pois essa evasão sempre o direciona para si próprio, ou seja, o maior desalento está interiorizado no seu "eu", como uma certa angústia existencial: "Mais fuir ne sert à rien: tout vous ramène toujours à vous-même". (LECHERBONNIER, 1983, p.15)

Com o propósito de analisar o pesar em relação ao tempo que se esvai levando consigo as lembranças felizes, tomamos como ponto de partida a expressão do tempo que passa, representada pelo escoamento da água do rio no poema, indicando com 
precisão a sucessão das horas, dos dias e dos anos. O amor resiste desesperadamente ao curso do rio parisiense que passa, tranqüilamente, inexoravelmente, sob essa ponte maciça, rígida, austera, insensível aos pensamentos dolorosos do amor, às sensíveis lembranças das sombras persistentes, advindas do sofrimento, e totalmente infelizes (ROUVEYRE, 1995, p.86).

Os elementos da imagem comportam os mesmos caracteres: a lentidão (v.15), a continuidade ininterrupta ("éternels") (v.10), a irreversibilidade (v.20-21). Ademais, relacionado ao símbolo do verso 1, "coule la Seine", retomado no verso 22, o campo lexical da passagem se organiza a partir dos verbos. Todos eles estão no presente, exceto "venait" (v.4). Esse tempo marca a continuidade ininterrupta: "passe" (v.4), "s'en va" (v.13-14), 'Passent" (v.19), repetido e retomado pelo particípio "passé" (v.20) e sobretudo "s'en vont", no segundo verso do refrão, retomado quatro vezes. A essa idéia da inexorabilidade do tempo, podemos associar a inconstância de muitos elementos da natureza, como o rio, a neve, tudo se resumindo ao estado da mudança, do efêmero. Assim, nessa associação, notamos que a natureza também é errance, passagem, inconstância, como o amor observado no poema, que se esvai com a fluidez do rio: "tout est fleuve, neige, tout se resume à l'état du devenir, de l'éphémère. La nature aussi est errance, passage, inconstance, comme l'amour..." (LECHERBONNIER, 1983, p.15)

Além disso, por meio de toda essa poesia pesarosa que lamenta o amor findo, observamos que o curso incessante do rio indica um estado sentimental, a nostalgia presente na passagem do tempo, representativa das decepções amorosas do eu poético que, segundo Rouveyre (1995, p.86), Apollinaire sabia por revelação íntima e por experiência já de sua vida, que a dor, especificamente do amor, era o alimento predestinado, necessário mesmo à fonte ou origem de sua arte. Mas sempre lembramos que essa associação biográfica serve simplesmente para esclarecer dados relevantes e jamais para limitar a análise da poética do autor.

Por meio da passagem do tempo, ainda podemos estudar as imagens e as correspondências existentes no poema, como: as águas do rio e o amor no verso 13: "L'amour s'en va comme cette eau courante", havendo igualmente uma associação do amor com o Seine, nos versos 21e 22; "Ni les amours reviennent", "Sous le Pont Mirabeau coule la Seine". Então, observamos o sentimento amoroso comparado à água corrente do rio, demonstrando toda a sua efemeridade, pois, segundo o poeta de Alcools, não existe amor feliz. Pois em vão é tentar resgatar o tempo perdido, pois nem o tempo 
passado, nem os amores retornam. A única defesa contra essa inexorabilidade do tempo é a sua abolição, criando um eterno presente, ou seja, presentificando as situações findas.

Em seguida, notamos a invocação do amor passado que, apesar das tempestades vivenciadas pelos dois amantes, não apresenta nenhuma característica dramática, nem desesperada: "Faut-il qu'il m'en souvienne" - o que não diminui a dor do poeta em relação ao fim do seu grande amor. Essa interrogação (pode apresentar também uma surpreendente ambigüidade, uma exclamação em forma de suspiro) se faz sob um tom de lassitude sem agressividade. O verso 4 ainda evoca tanto as lembranças felizes quanto as tristes: "La joie venait après la peine". O tempo presente encontrado na maioria dos versos indica a continuidade da lembrança, da mesma forma que o fluxo contínuo do rio indica uma história de amor acabada, sem retorno, como a passagem do tempo: "Ni les amours reviennent" (v.20-21). Desse modo, o rio "Seine" é o confidente desse eu-lírico mal-amado, no qual vê refletida a imagem de seu triste destino. Essa angústia pelo amor passado é também vista na união dos amantes atormentada pelo tempo que corre. A onda se cansa de ser observada, como se cansa o olhar mútuo dos amantes, em uma ligação que muito durou. (MORHANGE-BÉGUÉ \& LARTIGUE, 1993: p.23-24) - imagem essa que representa o desgaste de uma relação longa, através mesmo do olhar mútuo dos amantes, o qual indica que devora ou irradia qualquer chama de amor, por maior ou duradoura que seja.

Nesse sentido, podemos dizer que o rio é ao mesmo tempo o símbolo da destruição vagarosa e imperceptível, caminho que nos leva à morte irrefutável, sendo classificado como o espelho que reflete o desalento dos amantes, pois nesse caso o amor "s'en va comme l'eau courante". Assim, esse rio caminha para sua própria morte, aderindo à lei natural do universo de que tudo apresenta um fim, como o amor. O pesar devido à passagem do tempo e, conseqüentemente, o fim do amor podem ser explicados por meio de uma carta do poeta de agosto de 1916, para Jeanne-Yves Blanc: "Nada determina mais melancolia em mim do que essa fuga do tempo. Ela está em desacordo tão formal com meu sentimento, minha identidade, que é a própria origem de minha poesia" (Apud DÉCAUDIN, 1993, p.81). Ao trabalharmos com a inexorabilidade do tempo, observamos que o eu-lírico procura de qualquer forma retomar o seu amor perdido, mesmo que seja poetizando-o, pois, quando o resgata pela memória, presentifica aquilo que passou. 
Essa lembrança que o poeta apresenta em relação a sua fragilidade e a sua impotência mediante a passagem do tempo obriga-o a recuperar o passado imortalizando o presente, construindo assim uma cadeia cíclica através das reminiscências, mas que jamais recupera verdadeiramente o que findou, haja vista que o resgate nunca será do Mesmo, mas da Diferença. Essa cadeia cíclica é proveniente de um círculo eternamente descentrado, como apenas seleção que deixa subsistir o novo.

O eu lírico, por meio da água do rio e do tempo ininterrupto, apresenta a imagem simbólica da "permanência do ser", visto que a continuidade do rio representa a continuidade psíquica do poeta: "Les jours s'en vont je demeure”, pois a água e a vida representam um eterno recomeço. Além da imagem simbólica da ponte de concreto, que abruptadamente é humanizada, formada por dois braços "pont de nos bras"(v.9), o eulírico faz ressurgir de sua história passada uma lembrança sem amanhã. Essa desesperança é perenizada ainda na estrofe 2, "Les mains dans les mains restons face à face"(v.7), estando os olhares de seus protagonistas voltados para a eternidade. Mas logo essa idéia é desfeita, pois, embora haja essa presentificação ou eternização do passado, é ilusório e vão voltar ao mesmo. A impossibilidade da volta às coisas findas é explicitada na última estrofe, por meio do curso do rio, o qual jamais se inverte, e nunca corre ao contrário. Pois, mesmo que volte, "nem mesmo o rio em que entrais pela segunda vez é o mesmo que da primeira vez"(Heráclito de Éfeso). Enfim, essa recuperação do passado através da memória como metáfora do rio não o resgata de forma verdadeira pois, ao ser retomado, é simplesmente relembrado de forma ainda mais dolorosa.

Portanto, o poema "Le pont Mirabeau" apresenta a impotência da figura do malamado mediante a efemeridade do seu grande amor como conseqüência da inexorabilidade do tempo, em que predomina uma totalidade melancólica, caracterizando-o como elegíaco.

Assim, considerando os sistemas analisados, podemos partir para mais uma tópica presente no poema: 


\section{Aspectos da modernidade - Uma linguagem retirada do mais humilde cotidiano}

Nessa tópica, observamos que, embora haja uma certa distribuição regular dos versos e por conseguinte de suas rimas, ainda a presença de 4 estribilhos idênticos, notamos que a sua temática é retirada da "banalidade" cotidiana, uma ponte de concreto, como metáfora do tempo que passa. Logo, podemos dizer que a poesia apollinariana está em tudo, nas palavras mais sublimes e nas mais triviais:

Du plus trivial au plus raffiné, du plus banal au plus rare, du plus clair au plus ésotérique, aucun mot n'est exclu de son lexique où ne cessent de se composer et de se défaire d'imprévisibles amalgames tout en dissonances. (DÉCAUDIN, 1993, p.54)

Desse modo, vimos que é da linguagem banal que surge a linguagem poética em Apollinaire, não mais aquela do casticismo, com fortes inversões, conceitos e arcaísmos do Parnasianismo. Agora é a opulência na simplicidade. Notamos que a triste história de amor é contada por meio de imagens simples, como a água do rio e a ponte de concreto, utilizando o cotidiano, e tudo o que há nele, como material poético. Assim, notamos que o poeta trabalha com tudo aquilo que nutre o seu exterior, reservatório de imagens, utilizando-se de um elemento da natureza, a água do rio, e de uma imagem nada sublime para explicitar a questão do amor. Mas a sua criação poética não condiz com uma pura e simples reprodução das "imagens do cotidiano", mas sim como a chave decisiva que nos permite adentrar no mais profundo mistério de sua criação artística, a qual transforma a angústia humana em poesia:

Le premier point concerne la relation du créateur, poète ou peintre, à la nature. Il se nourrit du monde extérieur qui est pour lui un inépuisable réservoir d'images. Mais son rôle n'est pas de seulement le reproduire. (DÉCAUDIN, 1993, p.123)

Essa simplicidade lingüística e temática pode ser ainda observada no próprio desejo que o poeta Apollinaire apresenta: transformar tudo em matéria poética, metamorfoseando os objetos e situações mais simples em poesia: "É o próprio 
Apollinaire, o poeta mal-amado, quem expressa seu desejo de transformar tudo em matéria poética, ao dizer em seu diário que 'tudo se tornará Poesia, a história torna-se fábula, os próprios objetos, ao tornarem antigos, enfeitam-se de poesia. O respeito aos velhos, o culto dos mortos, tudo isso é a prova dessa transformação de tudo em poesia"'.(apud BURGOS et al, 1998, p.270).

Por fim, podemos trabalhar com uma outra característica que colabora para o desenvolvimento dessa tópica, a ausência de pontuação. Nessa notamos uma certa fluidez poética, sem as limitações rítmicas e melódicas de antemão. Assim, essas marcas de modernidade poética, como a utilização de vocábulos retirados do mais humilde cotidiano e, ainda, a ausência de pontuação, colaboram para compreendermos o que o poeta de Alcools busca demonstrar à maneira dos modernos, uma imagem o mais fiel do universo, tal como nós a percebemos.

Dando sequiência a essa poesia escrita com a tinta da melancolia como resultado do decurso do tempo, passamos ao poema "O anel de vidro".

\section{O ANEL DE VIDRO}

Aquele pequenino anel que tu me deste,

- Ai de mim - era vidro e logo se quebrou...

Assim também o eterno amor que prometeste,

- Eterno! Era bem pouco e cedo se acabou.

Frágil penhor que foi do amor que me tiveste, Símbolo da afeição que o tempo aniquilou, Aquele pequenino anel que tu me deste,

- Ai de mim - era vidro e logo se quebrou...

Não me turbou, porém, o despeito que investe

Gritando maldições contra aquilo que amou.

De ti conservo na alma a saudade celeste..

Como também guardei o pó que me ficou

Daquele pequenino anel que tu me deste...

(BANDEIRA, 1982, p. 42)

Ao analisarmos o subtema através do poema indicado, constatamos que ele está inserido em uma atmosfera de extrema tristeza e solidão, remetendo-nos ao tema de nosso projeto. Esses sentimentos são provocados pela passagem ininterrupta do tempo 
e, por conseguinte, pelo fim do amor. Assim, essa tristeza poética acentuada nos remete ao crítico Coelho (1982, p. 16), o qual analisa a questão do tédio na lírica bandeiriana:

o tédio, 'ce monstre délicat' da definição de Baudelaire em Les Fleurs du mal, e o tempo, outra entidade não menos monstruosa, são propícios ao surgimento da melancolia e da monotonia (palavras-eixo no léxico do Simbolismo, verdadeiros emblemas da angústia moderna). Esse tédio, que no livro A cinza das horas cai até dos telhados ("Enquanto a chuva cai", "Cartas de meu avô"), enlanguesce e deprime a consciência, submetendo-a, como em Verlaine, a crises de tristeza e lassidão indivisíveis e inexplicáveis. Por isso, a poesia bandeiriana é embebida ou construída por meio do pesar existente no ato de viver, o sofrimento é a sua fonte inspiradora.

Por meio de toda essa poesia nostálgica, Bandeira trabalha a expressão angustiante e inexorável da passagem do tempo em "O anel de vidro", cujos versos indicam o começo e o fim dos amores do sujeito poético, mostrando que o tempo passa ininterruptamente, deixando uma triste marca e uma saudade avassaladora: " Aquele pequenino anel que tu me deste," (v. 1); “Ai de mim - era de vidro e logo se quebrou..." (v. 2); "Símbolo da afeição que o tempo aniquilou," (v.6). Além dos verbos, quase todos no pretérito, exprimindo ações que ocorreram no passado, contrastando com o presente do eu poético, de sofrimento arraigado, de dor e ressentimento, com o passado de juras de eterno amor, observamos um suposto símbolo ou aliança, o anel de vidro, de uma união eterna: "me deste” (v. 1), “ se quebrou” (v. 2), “prometeste” (v. 3), “ aniquilou” (v. 6), “ investe” (v. 9), “ amou” (v. 3), “guardei” e “ me ficou” (v. 12). Através desses verbos no passado, exceto "investe", constatamos que o sujeito poético chora a dor de seu amor findo, fazendo uma associação do mesmo com algo concreto, um anel de vidro. Esse objeto por si só já representa uma certa fragilidade da relação entre o eu-poético e a sua amada, visto que o seu material é o vidro, substância sólida, frágil e translúcida.

Desta forma, o poeta apresenta uma história breve, frágil como o material de que é composto o anel (o vidro) - "era de vidro e logo se quebrou..." - tão vulnerável quanto a promessa de eterno amor que é muito em breve esquecida. Logo, o sujeito poético participa de uma história de amor tão breve que nem mesmo acredita que essa acabou. Por isso continua intensamente a busca de seu amor perdido. Desse modo notamos que, 
mesmo havendo uma certa aproximação dos amantes, essa foi tão efêmera que trouxe mais angústia do que se ambos não tivessem vivenciado história alguma, tornando o objeto amado ainda mais distante e inacessível.

Essa tragicidade na vida da figura do "mal-amado" pode nos remeter à "vida inteira que podia ter sido e que não foi” do próprio poeta Manuel Bandeira, refletindo classificação que fazia de suas relações amorosas, freqüentemente carregadas de frustrações, platonismo, abandono, insatisfação, perda, traição. Mas devemos salientar que essa análise psicopoética tem a prudência de não qualificar a obra bandeiriana por meio de seus dados biográficos, pois

os traços biográficos, se não determinam sua obra, ampliam as possibilidades de compreensão de sua poesia. Importa-nos considerar tais elementos apenas na medida em que auxiliem na explicitação da dinâmica de sua criação poética. É o próprio Bandeira quem se coloca incapaz de enfrentar a efemeridade de todas as vidas. (ROSENBAUM, 1993, p. 74).

O poeta é castigado pelo fracasso e, resignado, constrói um diálogo em que o interlocutor está presente apenas no discurso, nas várias marcas do pronome de $2^{\mathrm{a}}$ pessoa (a quem se fala).

A imagem do anel, como já dissemos, é característica de um amor efêmero, da amargura que o eu-poético sente ao perder o seu amor que jurava não ter princípio nem fim. Dessa forma, o eu-lírico, caracterizado como "mal-amado", busca reviver os momentos felizes que viveu, mesmo que esses tenham sido demasiadamente rápidos pois, para assumir o papel de "mal-amado", busca reviver o seu passado de juras de eterno amor, como uma história cíclica, na qual o fim impulsiona a busca pelo começo. Como resposta a essa inexorabilidade do tempo que transforma todas as coisas em reminiscências, sobretudo o amor, que se esvai com passar das estações, o sujeito poético cria a ilusão de um retorno consolador em que, como o anel de vidro é frágil e se quebrou, representa um círculo que não tem início nem fim. Diante do eterno retorno na história elegíaco-amorosa do eu lírico bandeiriano, que busca reviver aquilo que passou, retomamos a teoria do tempo não-reconciliado de Deleuze, posto que essa circularidade de um retorno simplista representa uma falsa aparência de reencontro com o vivido. 
A recusa em aceitar a fugacidade de todas as coisas pela passagem ininterrupta do tempo traz nostalgia ao sujeito poético de "O anel de vidro", pois esse é incapaz de interromper esse ciclo, a não ser poetizando aquilo que vivenciou em um passado indeterminado, revivendo a sua história de eterno amor na criação poética.

Toda essa busca pelo objeto perdido é ainda explicitada pela indiferença, recusa, ou menosprezo da mulher amada, enfatizando ainda mais que a história de amor findou por completo. Vide versos 9 e 10: "Não me turbou, porém, o despeito que investe"; "Gritando maldições contra aquilo que amou", os quais mostram que, apesar do desprezo da mulher, o eu lírico continua a alimentar a nostalgia do seu amor infeliz, simbolizado pelos fragmentos do anel de vidro: "De ti conservo na alma a saudade celeste...", "Como também guardei o pó que me ficou”, "Daquele pequenino anel que tu me deste..." - simbolizando a permanência do ser, com versos indicativos de uma poesia que se inscreve no eterno. Permanência essa nutrida pelo fato de o sujeito poético alimentar o seu amor infeliz nas lembranças que lhe restaram de sua relação, os fragmentos e o pó do anel, conservando na alma a saudade e fazendo dela eterna e constante em sua vida. Desse modo, essa "saudade celeste" que o eu-lírico nutre como lembrança de sua breve história de amor remete-nos ao significado do vocábulo "saudade", "soêdade, soidade, suidade", mal da ausência, vontade de ver (Heimweh), morrer de amor, tal como ela surge na cantiga medieval de João Roiz ("Senhora, partem tam tristes/ meus olhos por vós, meu bem,/ que nunca tam tristes vistes/ outros nenhuns por ninguém") (BRAYNER, 1980 p. 244). Assim, a partir dessa vontade de estar junto à sua amada, ou do pesar que a ausência da mesma provoca, mencionamos uma frase lacaniana que exemplifica com destreza esse vazio resultante do mal de amar representado na poesia: "O desejo se sublima em retorno de um vazio central, a escrita passa a ser concebida como um gesto desejante de uma reconciliação com a Coisa perdida - lugar central do desejo" (apud ROSENBAUM, 1993 p.128). Desse modo, notamos no poema um cunho romântico, mesmo porque esses em suas composições fizeram a volta ao mundo medieval. Assim, "a saudade é sentimento que nasceu da conjugação do paganismo com o cristianismo. Esse encontro deu-se na Idade Média. Quem diz paganismo diz Grécia. O Medievo está cheio de recordações gregas" (BRAYNER, 1980 p. 244 - 245).

Portanto, o poema "O anel de vidro" é característico do gênero elegíacoamoroso, em que não há a reciprocidade no amar, mas sim uma surpreendente 
exposição poética do desespero amoroso, do mal da ausência e da separação dos amantes.

Considerando a efemeridade do amor e a inexorabillidade do tempo podemos trabalhar com o subtema que decorre desses dois primeiros:

\section{Aspectos da modernidade - uma linguagem retirada do mais humilde cotidiano}

Por meio desse subtema, notamos que, embora o poema seja composto por versos alexandrinos, distribuídos em duas quadras e uma quintilha, com rimas alternadas e, portanto, com uma certa regularidade, há uma inovação em sua temática, "o cotidiano como material poético". Vemos que o tema não é mais extraído de um cosmo sublime, como antes, mas sim do mais humilde cotidiano, no qual notamos o "poetizar a banalidade cotidiana, a realidade decaída do mundo". Dessa forma, o poema analisado apresenta como tema "um anel de vidro", símbolo da relação efêmera que os dois amantes vivenciaram. Essa breve história é contada por meio de uma linguagem simples, não através de temas e vocábulos esmerados, como por exemplo no Parnasianismo. Assim

o ideal da poética de Bandeira, é o de uma mescla estilística inovadora e moderna, uma vez que persegue uma elevada emoção poética através das palavras mais simples, de todo dia. Para o poeta, o alumbramento, revelação simbólica da poesia, pode dar-se no chão do mais 'humilde cotidiano', de onde o poético pode ser desentranhado, à força da depuração e condensação da linguagem, na forma simples e natural do poema. (ARRIGUCCI, 1990 p. 15).

Essa simplicidade lingüística e temática pode ser ainda exemplificada por meio da escolha da cantiga infantil que deu origem ao poema, "Ciranda Cirandinha", a qual nos remete ao mundo imaginário, que por si só já nos apresenta uma clareza e uma simplicidade inconfundíveis. Logo, nesse poema, "a infância aparece na fala mesma da criança, fazendo soar pela voz lírica um eu infantil. Evoca-se a infância sem 
explicitação direta da falta através de um tom nostálgico, mas o ausente acaba por reviver na brincadeira de uma trova de uma música, que recriam a atmosfera encantatória infantil" (ROSENBAUM, 1993 p. 53).

A linguagem poética simples, livre do artificialismo da poética parnasianosimbolista, proporciona-nos temas os mais variados e "banais" como material para a poesia, erradicando os temas rebuscados anteriormente escolhidos. Mas devemos lembrar que essa inovação ainda é superficial nos primeiros livros de Bandeira, quase ínfima, apresentando-se poucos poemas com essas marcas de renovação, os quais já anunciam a liberdade de criação que será acentuada no modernismo:

assim, na companhia paterna iam-me embebendo dessa idéia que a poesia está em tudo - tanto nos amores quanto nos chinelos, tanto nas coisas lógicas como nas disparatadas'. O poeta veio, portanto, para contribuir na incorporação à poética nacional do "humilde cotidiano", baseado em "locuções trivialíssimas" (LOPEZ, 1987 p. 06).

Por meio dessa linguagem poética simples, Bandeira observa que "a poesia não está mais no mundo da lua, mas na terra dos homens, no chão do cotidiano", utilizandose de um estilo humilde, com palavras do dia-a-dia, situada perto do chão" (afinal, humilde, humilis, procede de humus) (SCHWARZ, 1983, p. 108). Desse modo, vimos que no poema "O anel de vidro" essa simplicidade lingüística é acentuada, pois o sujeito-poético parte de um "anel de vidro", objeto banal, frágil, de pouquíssimo valor, diferentemente, por exemplo, de um "anel de diamante", que valorizaria e daria quiçá mais sustentação a essa breve história de amor.

Embora haja uma certa simplicidade temática no poema, devemos mencionar que ela não desvaloriza ou banaliza sua construção; ao contrário, sua complexidade está nessa aparente modéstia e espontaneidade lingüística, pois:

esse movimento em busca da simplicidade tem de fato algo de misterioso, na medida em que evita todo mostrarse ostensivo, seja pelo espetáculo da forma ou da emoção, para recolher-se ao redor do essencial, do reduto último daquele 'luzir sensível da idéia' (na expressão de Hegel), despojado de todo brilho fácil. Sugere, em troca, outro tipo de facilidade, enganosa, porque esconde a verdadeira dificuldade no mais fundo. (ARRIGUCCI, 1990 p.48) 
Portanto, essa linguagem poética inscrita por meio do simples na dependência do complexo, retirada como disse Bandeira do mais "humilde cotidiano", apresenta-nos aspectos da poesia moderna, valorizando o fazer poético pela sua beleza enigmática criadora e não pelos seus arquétipos temáticos sugeridos de antemão.

\section{Apollinaire e Bandeira}

Nos dois poemas encontramos o triste fim do amor como resultado da inexorabilidade do tempo, apresentando um cosmo de tamanha melancolia que o término do amor se equipara ao desespero do olhar daquele que não pode reter o tempo que passa. Desse modo, o eu-lírico de tais poemas apresenta a angústia pelo tempo ininterrupto que leva embora os seus amores e o faz distanciar de seus anos de gozo.

Assim, com o propósito de analisar o pesar em relação ao tempo que se esvai levando consigo as lembranças felizes, tomamos como ponto de partida a expressão do tempo que passa, representada pelo escoamento da água do rio no poema "Le Pont Mirabeau", indicando com precisão a sucessão das horas, dos dias e dos anos. O amor resiste desesperadamente ao curso do rio parisiense que passa, tranqüilamente, inexoravelmente, sob essa ponte maciça, rígida, austera, insensível aos pensamentos dolorosos do amor, às sensíveis lembranças das sombras persistentes ou advindas do sofrimento, e totalmente infelizes (Rouveyre, 1955, p.86).

Logo, os elementos da imagem comportam os mesmos caracteres: la lenteur (v.15), a continuidade ininterrupta "éternels" (v.10), a irreversibilidade (v.20-21). Ademais, relacionado ao símbolo do verso 1, "coule la Saine", retomado no verso 22, o campo lexical da passagem do tempo se organiza a partir dos verbos. Todos eles estão no presente, exceto "venait" (v.4). Esse tempo marca a continuidade ininterrupta: "passe" (v.9), "s'en va" (v.13-14), "Passent" (v.19), repetido e retomado pelo particípio "passé" (v.20) e sobretudo "s'en vont", no segundo verso do refrão, retomado quatro vezes (MORHANGE-BÉGUÉ \& LARTIGUE, 1993, p.23).

Por meio de toda essa poesia nostálgica, Bandeira de modo similiar trabalha a expressão angustiante e inexorável da passagem do tempo em "O anel de vidro", cujos versos indicam o começo e o fim dos amores do sujeito poético, mostrando que o tempo passa ininterruptamente, deixando uma triste marca e uma saudade avassaladora: "Aquele pequenino anel que tu me deste," (v.1); "Ai de mim - era de vidro e logo se quebrou..." (v.2); "Símbolo da feição que o tempo aniquilou," (v.6). Os verbos, quase todos no 
pretérito - diferentemente dos verbos em "Le Pont Mirabeau", que estão no presente, mas que exprimem do mesmo modo a passagem do tempo e dos sentimentos - exprimindo ações que ocorreram no passado, contrastam o presente do eu-poético, de sofrimento arraigado, de dor e ressentimento, com o passado de juras de eterno amor, por meio de um suposto símbolo ou aliança, o anel de vidro. Como em Apollinaire, esse objeto por si só já representa uma certa fragilidade da relação entre o eu-poético e a sua amada, sobretudo se pensarmos nos elementos da natureza mencionados em "Le Pont Mirabeau", que são inconstantes e de fácil destruição (a neve, o rio etc.), e os compararmos com o anel cujo material constitutivo é vidro, substância frágil e translúcida.

Dessa forma, o poeta apresenta uma história breve, frágil como o material de que é composto o anel (o vidro)- "era de vidro e logo se quebrou..." - tão vulnerável quanto a promessa de eterno amor que é muito em breve esquecida. Assim, mediante tal fugacidade do tempo e dos sentimentos, demostrando toda a efemeridade que existe no ato de amar, observamos uma certa recusa, por parte do eu-lírico bandeiriano, em aceitar todo esse processo, sendo incapaz de interromper esse ciclo, a não ser poetizando aquilo que vivenciou em um passado indeterminado, revivendo a sua história de eterno amor na criação poética. Nota-se, então, que toda essa busca pelo objeto perdido é também explicitada pela indiferença, recusa ou menosprezo da mulher amada, enfatizando ainda mais que a história de amor findou por completo. Vide para isso os versos 9 e 10: "Não me turbou, porém, o despeito que investe", "gritando maldições contra aquilo que amou", os quais mostram que, apesar do desprezo da mulher, o eu-lírico continua a alimentar a nostalgia de seu amor infeliz, simbolizado pelos fragmentos do anel de vidro: "De ti conservo na alma a saudade celeste...", "Como também guardei o pó que me ficou”, "Daquele pequenino anel que tu me deste..." - simbolizando a permanência do ser, com versos indicativos de uma poesia que se inscreve no eterno. Permanência essa nutrida pelo fato de o sujeito poético alimentar o seu amor infeliz nas lembranças que lhe restaram de sua relação, os fragmentos e o pó do anel, conservando na alma a saudade e fazendo dela algo eterno e constante em sua vida.

Em Apollinaire, as imagens relativas à passagem do tempo e dos sentimentos refletem também a questão da "permanência do ser", pois observamos que o sujeito poético apollinairiano, como o bandeiriano, procura de qualquer forma retomar seu amor perdido, mesmo que seja poetizando-o: o resgate pela memória "presentifica" aquilo que passou. Essa lembrança que o eu-lírico apresenta em relação à sua fragilidade e 
impotência diante da passagem do tempo obriga-o a recuperar o passado imortalizando o presente, construindo assim uma cadeia cíclica através das reminiscências. Nesse sentido, o eu-poético, por meio da água do rio e do tempo ininterrupto, apresenta a imagem simbólica da "permanência do ser", visto que a continuidade do rio representa a continuidade psíquica do poeta: “Les jours s'en vont je demeure”. A água e a vida desse sujeito "mal-amado" representam, pois, um eterno recomeço.

Mesmo constatando o aspecto da "permanência do ser" por meio da circularidade na poética de Bandeira e Apollinaire, notamos que há uma impossibilidade de retorno às coisas findas, pois o curso do rio jamais se inverte, nunca corre ao contrário. E, ainda, os fragmentos do anel de forma alguma recompõem a história de amor vivenciada. Logo, nos dois poemas a recuperação do passado por meio da memória, como metáfora do rio e do anel, não o resgata de forma verdadeira pois, ao ser retomado, é simplesmente relembrado de forma ainda mais dolorosa.

Portanto, os poemas "O anel de vidro" e "Le Pont Mirabeau" são característicos do gênero elegíaco-amoroso, em que não há reciprocidade no amar, mas sim uma surpreendente exposição poética do desespero amoroso, do mal da ausência e da separação dos amantes.

Além disso, constatamos mais uma semelhança entre os poemas analisados, considerando a tópica:

\section{Aspectos da modernidade - Uma linguagem retirada do mais humilde cotidiano}

Aqui observamos que tanto "Le Pont Mirabeau" quanto "O anel de vidro" apresentam o cotidiano como material poético, extraindo os seus temas não mais de um cosmos sublime, como antes, mas sim do mais humilde cotidiano, já que "poetizam a banalidade cotidiana, a realidade decaída do mundo" (ARRIGUCCI, 1990, p. 24).

Assim, notamos que o poema de Bandeira apresenta como tema "um anel de vidro", símbolo da relação efêmera que os dois amantes vivenciaram. A breve história de amor é contada por meio de um estilo de absoluta simplicidade, não através de termos e vocábulos esmerados. Essa simplicidade lingüística e temática pode ser ainda exemplificada por meio da escolha da cantiga infantil que deu origem ao poema, "Ciranda Cirandinha", a qual nos remete ao mundo infantil, que por si só já nos apresenta uma clareza e uma simplicidade inconfundíveis. Neste sentido, no poema "O anel de vidro" 
essa simplicidade é acentuada, pois o sujeito poético parte de um "anel de vidro", objeto banal, frágil, de pouquíssimo valor se comparado, por exemplo, com um "anel de diamante", que valorizaria e daria mais sustentação a essa breve história de amor.

De forma similar constatamos o mesmo aspecto no poema de Apollinaire, "Le Pont Mirabeau", no qual a triste história de amor é contada por meio de imagens simples, como a água do rio e a ponte de concreto, utilizando o cotidiano, e tudo o que há nele, como material poético. Assim, notamos que o poeta francês, do mesmo modo que o brasileiro, trabalha com tudo aquilo que nutre o seu exterior, reservatório de imagens, utilizando-se de um elemento da natureza, a água do rio, e de uma imagem nada sublime para explicitar também o triste fim de uma história de amor. Como Bandeira, Apollinaire apresenta o desejo de transformar tudo em matéria poética, buscando nos objetos e nas situações mais simples, os termos para a sua poesia, valorizando os "pequeninos nadas", e convertendo-os em questões sublimes.

Atentando ainda para a temática da efemeridade do amor e da inexorabilidade do tempo, analisamos outros dois poemas que seguem tal perspectiva, "Crépuscule" e "Ao Crepúsculo”. Seguindo a tendência crepuscular caracterizada pela melancolia e pela valorização dos temas do cotidiano, iniciamos com a análise do poema "Crépuscule", de Apollinaire.

\section{Crépuscule}

\section{À Mademoiselle Marie Laurencin}

Frôlée par les ombres des morts

Sur l'herbe où le jour s'exténue

L'arlequine s'est mise nue

Et dans l'étang mire son corps

Un charlatan crépusculaire

Vante les tours que l'on va faire

Le ciel sans teinte est constellé

D'astres pâles comme du lait

Sur les trétaux l'arlequin blême

Salue d'abord les spectateurs

Des sorciers venus de Bohême

Quelques fées et les enchanteurs 
Ayant décroché une étoile

Il la manie à bras tendu

Tandis que des pieds un pendu

Sonne en mesure les cymbales

L'aveugle berce un bel enfant

La biche passe avec ses faons

Le nain regarde d'un air triste

Grandir l'arlequin trismégiste

Nesse, notamos imagens advindas do dia que se esvai, em uma ambientação em que transborda pesar como resultado do mal de amar, mesmo que de forma implícita. Vimos também uma personagem tocada pelas sombras da morte, a Arlequine, que nua sob a relva, observa seu corpo em um lago: "Frôlée par les ombres des morts", "Sur l'herbe où le jour s'exténue", "L'arlequine s'est mise nue", "Et dans l'étang mire son corps" (V.1 a 4). As águas desse espelho mágico/l'étang são turvas e quiméricas, e têm como "fleuves/Rhénanes", os sonhos como constituição primordial. Assim, todo esse clima melancólico de meio-tom direciona-nos para a temática crepuscular, que é a poesia de um grupo de jovens escritores sem uma única alegria para cantar. Esses representavam a revolta de uma geração contra os seus antercessores, além de sofrerem de um novo mal do século, a "consomption", que a essa época era característica dos jovens com "tuberculose pulmonaire", em sua maioria candidatos à "étesie", emagrecimento extremo decorrente de tal moléstia. Os crepusculares almejavam a vida tranqüila e simples da longínqua província, ou seja, tinham a nostalgia do campo.

Vimos que no poema "Crépuscule" há a valorização do que é sombrio e melancólico, como no crepuscolarismo, bem como um cenário, na primeira estrofe, natural, com a relva e o lago banhados pelo meio-tom do dia que se extingue. Notamos também a presença da temática do cotidiano, uma das características dos poetas crepusculares, pois a Arlequine, no crepúsculo, nua sobre um gramado, observa seu corpo no lago, cena de inteira singeleza. Ainda para reforçar essa atmosfera anuviada pelas suas cores apagadas, temos o corpo da Arlequine também lívido, como o restante da ambientação.

Observamos que o meio-tom do crepúsculo perdura na segunda estrofe, pois o “charlatan" é caracterizado como "crépusculaire", o céu, embaciado pela chegada da noite, tem astros "pâles comme du lait" e as constelações, cuja luz própria poderia 
amenizar o tom sombrio e trazer beleza ao manto negro que se aproxima com o escoar do dia, são apagadas em um céu sem cor: "Um charlatan crépusculaire", "Vante les tours que l'on va faire", "Le ciel sans teinte est constellé", "D'astres pâles comme du lait" (V.5 ao 8).

Sendo assim, observamos na estrofe seguinte, personagens distanciados da realidade, representantes do universo onírico como: "fées, enchanteurs, sorciers advindas da Bohême, o país do Drácula, e o Arlequin, que junto à Arlequine, fazem parte da Commedia dell'arte, salientando ainda mais a questão da ambientação turva e misteriosa da temática crepuscular. Nessa, o Arlequin muito pálido "blême", como o cenário onde está inserido, apresenta-se em um circo saudando os espectadores. Mas essa saudação, de acordo com a atmosfera sombria e melancólica do poema, é pesarosa e imprecisa, contrária do que deveria ser, pois em um circo se tem alegria e cores vivas, cujo maior representante é o palhaço, aqui no caso, o Arlequin: "Sur lês tréteaux l'arlequin blême", "Salue d'abord lês spectateurs", "Dês sorciers vênus de Boême", "Quelques fées et lês enchanteurs" (V.9 ao 12).

Nesse viés, devemos considerar a história das personagens, Arlequin e Arlequine, para indicarmos um outro fator que colabora para a sustentação desse cenário triste e apagado, a existência do amor frustrado. Nessa, observamos, segundo a clássica comédia italiana, que se trata de um amor servil e desesperado de um bufão mágico, "Arlequin", além de fazer parte de um trio amoroso junto a Pierrô e Colombina. Esse triângulo apresenta Arlequin como amante de Colombina, que na verdade é namorada de Pierrô, o que nos indica o sofrer por amor, pois o bufão, apesar de farsante e dissimulado, vive na incerteza de amar aquela que é oficialmente de outro. Dessa maneira, além de o eu-lírico apresentar indiretamente essa triste história de amor, notamos que tal poema foi dedicado à Mademoiselle Marie Laurencin, uma pintora com quem Apollinaire teve uma ligação amorosa que lhe inspirou a maior parte dos poemas de Alcools, e a quem permaneceu fiel, mesmo após o término da relação, durante seis anos, de 1907 a 1913. Nesse caso, mais uma vez, não tivemos o intuito de fazer uma leitura biográfica da poética apollinairiana, pois, segundo Tzvetan Todorov, "a leitura de textos poéticos não deve se confundir com a pesquisa biográfica que, quer queira ou não, reduz o texto ao estatuto de documento ou pretexto" (apud VAILLANT, 1992. p.110).

Prosseguindo, vimos que tal atmosfera melancólica e feérica subsiste no poema, pois o Arlequin retira uma estrela do céu e a maneja com os braços estendidos, enquanto um "enforcado/pendu" toca címbalos (um morto-vivo), confirmando as sombras da 
morte da primeira estrofe, e criando um clima sombrio de finitude, com uma música mortífera de fundo: "Ayant décroché une étoile", "Il la manie à bras tendu", "Tandis que des pieds um pendu", "Sonne en mesure les cymbales" (V.13 ao 16).

Esse cenário de lamento e de nuanças finaliza com imagens que reforçam tal pesar, a primeira, um cego que embala um belo bebê, o que nos direciona mais uma vez para a imprecisão, pois, privado da visão, esse representa o mundo das trevas, embora tenha algo que caracterize a vida, a criança em seus braços: "L'aveugle berce um bel enfant" (V.17). Em seguida, a corça que passa lentamente com os seus filhotes, dandonos a impressão de passagem do tempo e de que incita vagarosamente uma caminhada triste e árdua para a defesa dos seus: "La biche passe avec ses faons" (V.18). E por último, um anão que, provavelmente, saiu do circo na "campagne crépusculaire" e que, com um ar triste, devido à sua baixa estatura, que jamais chegará a desse personagem, observa "grandir" o "Arlequin trimégiste" (epíteto dado a Hermès, le trois fois très grand, deus entre outros dos estados e ginásios): "Le nain regarde d'un air triste", "Grandir l'arlequin trimégiste"(V.19 e 20). Essa última imagem corrobora a atmosfera sombria e enigmática do poema, pois o anão, sendo considerado como um velho deus da natureza, gênio da terra e do solo, conhece os seus segredos, exprime-se por enigmas, enfatizando a questão imprecisa da ambientação crepuscular e ainda salientando o topos da nostalgia do campo:

mas o anão é sobretudo um guardião tagarela, segundo as tradições; um tagarela, é verdade, que se exprime de preferência por enigmas. Se ele parece ter renunciado ao amor, continua, entretanto, ligado à naturez da qual conhece os segredos. Por isso pode servir de guia, de conselheiro. Participa das forças telúricas e é considerado como um velho deus da natureza (CHEVALIER \& GHEEBRANT,1992, p.49)

Enfim, "Crépuscule" é um poema que tem, como temas nodais, a melancolia e o meio-tom característicos da temática crepuscular, bem como a dor do mal de amar representativa da decepção de um eu-lírico que perdeu a sua amada com o decurso do tempo.

Dando sequiência à temática elegíaco-amorosa partimos para o poema "Ao Crepúsculo. 


\section{Ao Crepúsculo}

O crepúsculo cai tão manso e benfazejo

Que me adoça o pesar de estar em terra estranha

E enquanto o ângelus abençoa o lugarejo, Eu penso em ti, apaziguado e sem desejo, Fitando no horizonte a linha da montanha.

A montanha é tranqüila e forte, e grande e boa. Ela afaga o meu sonho. E alegra-me pensar (Tanto a saudade a um tempo acalenta e magoa!)

Teces o meu sonho, ouvindo e vendo o mar.

Embalada na voz do grande solitário, Tu mortificarás teu casto coração $\mathrm{Na}$ dor de revocar o noivado precário. (Ah, por que te confiei o meu desejo vário? Por que me desvendaste a tua sedução?)

Se nos aparta o espaço, o tempo - esse nos liga.

A lembrança é no amor a cadeia mais pura.

Tu tens o grande Amigo e eu tenho a grande Amiga:

O mar segredará tudo quanto eu te diga, E a montanha dir-me-á tua imensa ternura.

Podemos dizer que esse poema segue tal tópica, pois a cena se passa no findar do dia, no cair do crepúsculo, havendo no eu-lírico um pesar por estar em terra estranha, tudo sendo embalado na voz do grande solitário que fita no horizonte a linha da montanha, pensando naquela que teve um dia em seus braços:"O crepúsculo cai, tão manso e benfazejo", "Que me adoça o pesar de estar em terra estranha", "E enquanto o ângelus abençoa o lugarejo", "Eu penso em ti apaziguado e sem desejo", "Fitando no horizonte a linha da montanha" (V.1 a 5).

Esse tom crepuscular é visto ainda na estrofe seguinte, visto que a ambientação é descrita por meio da tarde que se escoa, tendo a natureza como cenário que emana tédio e nostalgia, sendo a saudade o sentimento primeiro do eu-lírico que afirma ter perdido aquela que amou para o tempo. Também é importante destacar o caráter simbólico da montanha no poema, que, aqui, parece proporcionar o sonho do sujeito poético e amenizar-lhe a dor de tamanha perda, pois essa "pode ser caracterizada como sendo 
uma das representções do SELF, posto que possui uma simbólica de centro de omphalos, tanto que em todas as tradições aparece como sendo uma imagem da imortalidade. Ela é um local onde se processam as revelações ou a meta de uma longa busca para a eternidade"(Araújo, ver bibliografia).

Não é por acaso que a imagem da montanha aqui produz essa sensação de sustentar a volta ao que findou, pois a longa busca para a eternidade seria, no caso, a busca para eternizar o que se esvaeceu com o passar do tempo, o grande amor do sujeito poético: "A montanha é tranqüila e forte , e grande e boa.", "Ela afaga o meu sonho. E alegra-me pensar”, “(Tanto a saudade a um tempo acalenta e magoa!)”. Em se tratando da questão da procura por aquilo que permaneceu no passado, temos outra imagem nos versos 9 e 10 que confirma tal problemática: "Que tu na doce paz da tarde que se escoa,", “Teces o mesmo sonho, ouvindo e vendo o mar." Dessa forma, vimos que a ameaça de finitude já se concretiza, pois, com o escoar da tarde, tem-se a impressão de que o processo de morte do dia e de todas as suas lembranças começou. Logo, esse pronome "tu" parece já fazer parte do passado, pois se apresenta apenas no sonho do sujeito poético mal-amado, ou seja, no cenário banhado pela beleza e triste melodia da solidão do mar. Nesses versos, a imagem do mar é sugestiva, visto que:

Representa a dinâmica da vida, tudo sai e retorna a ele: lugar dos nascimentos, das transformações e dos renascimentos. Águas em movimento, o mar simboliza um estado transitório entre as possibilidades ainda informes as realidades configuradas, uma situação de ambivalência, que é a de incerteza, de dúvida, de indecisão, e que pode se concluir bem ou mal. Vem daí que Omar é ao mesmo tempo a imagem da vida e a imagem da morte. (BIEDERMANN, 1993, p. 592)

Observamos que, por simbolizar o renascimento, o eu-lírico, por meio da imagem do mar no mundo onírico, revive aquele amor acabado, e reforça a atmosfera crepuscular, tanto pela fuga para o cenário natural quanto pela ambivalência e imprecisão que esse representa, junto às nuanças e o meio-tom. Sendo assim, o mar aqui pode simbolizar a vida - o renascimento desse amor - mesmo que no sonho, e a morte, a certeza de que tudo permanece apenas na memória.

Temos na estrofe seguinte a mesma atmosfera melancólica por conta da triste história de amor. O eu-lírico se mostra solitário e deseja mortificar o casto coração de 
sua amada com a dor do remorso, devido ao noivado precário que provocou: "Embalada na voz do grande solitário,", “Tu mortificarás teu casto coração", "Na dor de revocar o noivado precário." (V. 11 a 13). Esse continua a lamentar o pesar que sente nos versos subseqüentes, pois, por meio de duas indagações, se direciona àquela para quem confiou o seu desejo: “(Ah, por que te confiei o meu desejo vário?”, “ Por que desvendaste a tua sedução?)" (V. 14 e 15). Nesses, o sujeito poético se apresenta inconformado por ter confiado os seus sentimentos àquela mulher e também por ela ter desvendado a sua sedução, o que nos dá a impressão de que todo esse noivado, não passou apenas de dissimulação. Observamos ainda que toda essa poesia se inscreve na banalidade do cotidiano, tendo um noivado precário como motivo, a tarde que se escoa, os elementos da natureza como o mar e a montanha, tudo com uma inteira singeleza característica da poesia crepuscular.

Na última estrofe há a confirmação da separação dos amantes, mas ao mesmo tempo o resgate, ainda que mnemônico e imagístico, pela lembrança cujas imagens das encostas da montanha e do mar servem de canais de comunicação entre os dois: "Se nos aparta o espaço, o tempo - esse nos liga.", “A lembrança é no amor a cadeia mais pura.", "Tu tens o grande Amigo e eu tenho a grande Amiga:", "O mar segredará tudo quanto eu te diga,", "E a montanha dir-me-á tua imensa ternura." (V.16 a 20). Assim, o poema finaliza com imagens da natureza - mar, montanha, nostalgia do campo- que possibilitam a volta do que foi perdido, com toda a sua significação simbólica de renascimento e imortalidade, mas ao mesmo tempo dá a idéia de finitude, pois o próprio crepúsculo, que é o cenário de tal poema, representa a morte do dia, ou do noivado

precário. É, pois, importante destacar que somente por meio da atmosfera onírica na imprecisão do tom crepuscular que o sujeito poético recompõe a sua história.

Em resumo, "Ao Crepúsculo" é um poema inscrito com a tinta toldada do meiotom crepuscular, da qual transborda melancolia e dor pela distância da mulher amada.

\section{Bandeira e Apollinaire}

Partindo para o diálogo entre as poéticas bandeiriana e apollinairiana, tomamos para estudo os dois poemas "Crépuscule" e "Ao Crepúsculo", que apresentam um cosmo exacerbadamente melancólico, fruto do mal de amar como conseqüência da passagem do tempo. Eles seguem a tendência crepuscular, caracterizada pelo pesar e pela valorização dos temas do cotidiano, como palco de tristes histórias de amor findas. 
Nesse viés, observamos em "Crépuscule" imagens advindas do dia que se esvai, em uma ambientação que transborda pesar, como resultado do mal de amar, mesmo que de forma implícita.

É o que ocorre em “Ao Crepúsculo”, pois tudo se passa no findar do dia, no cair do crepúsculo, havendo no eu-lírico um pesar por estar em terra estranha, fitando no horizonte a linha da montanha e pensando naquela que teve um dia em seus braços.

Em ambos os poemas, encontramos o mesmo cenário angustiante de fim do dia/ símbolo da passagem do tempo, característica da temática crepuscular, que é a poesia de um grupo de jovens escritores que se mostrava farto da vida.

É importante salientar que não podemos classificar os poetas estudados como crepusculares, pois esses se encontram em outra fase da literatura, apesar de recuperarem muitos traços de tal tendência. Assim, tanto Apollinaire quanto Bandeira, em sua fase inicial, fizeram uma poesia exacerbadamente melancólica, de uma singeleza notável, buscando sempre a natureza como cenário para as suas angústias e uma linguagem retirada do mais humilde cotidiano. Uma outra relação com essa poesia pesarosa dos jovens crepusculares é a própria vida de Bandeira, sempre ameaçada pela tísica, o que o aproxima sobremaneira dessa falta de crença na vida dos poetas do crepuscolarismo, que também cantavam poeticamente a dor do fundo dos hospitais e dos cemitérios.

Logo, vimos que em "Crépuscule” há a valorização do meio-tom e da melancolia, como no crepuscolarismo, constituído por um cenário na primeira estrofe, natural, com a relva e o lago banhados pelas nuanças do dia que se extingue, além dos astros pálidos como leite e do "charlatain crépusculaire".

De forma semelhante encontramos em "Ao Crepúsculo" uma atmosfera pesarosa e marcada pelo toldo do cair da do dia, também um cenário notadamente natural e cotidiano, pois temos imagens do escoar da tarde e de elementos da natureza, como o mar e a montanha, tudo de uma inteira singeleza característica da poesia crepuscular.

Outra aproximação que podemos fazer é a questão da temática elegíaco-amorosa presente nos poemas. Em "Crépuscule", essa tópica está subentendida nos versos 3 e 9: “L'arlequine s'est mise nue", "Sur les tréteaux l'arlequin blême”. Desse modo, devemos considerar a história das personagens "Arlequin e Arlequine" para indicarmos um outro fator que colabora para a sustentação desse cenário triste e apagado, a existência de uma relação amorosa frustrada. Nessa, observamos segundo à clássica comédia italiana, que 
se trata de um amor servil e desesperado de um bufão mágico "Arlequin", além de fazer parte de um trio amoroso junto a Pierrô e Colombina. Dessa maneira, além do eu lírico apresentar indiretamente essa triste história de amor, notamos que tal poema foi dedicado à Mademoiselle Marie Laurencin, uma pintora com quem Apollinaire teve uma ligação amorosa, que lhe inspirou a maior parte dos poemas de Alcools.

Considerando tais elementos intertextuais, vimos que o topos do amor triste possui extrema significação, como em "Ao Crepúsculo", cuja tópica também aparece como tema gerador da melancolia que inunda todo o poema, apesar de nesse manifestarse de forma direta. Assim, já na primeira estrofe, vimos que o sujeito poético pensa em sua amada, representada pelo pronome "ti": "Eu penso em ti, apaziguado e sem desejo" (V.4). Em seguida, fala da saudade que ficou daquela cuja lembrança permaneceu apenas nos seus sonhos. E ainda, na terceira estrofe, em que o pesar pelo fim do amor aparece representado pelo noivado precário e pela solidão do eu-lírico mal-amado.

Por conta dessa temática elegíaco-amorosa é importante mencionar que tanto Bandeira quanto Apollinaire abordam enfaticamente essa questão em seus poemas. Como já mencionamos, os dois poetas fizeram do amor um canto pesaroso, no qual a amada se mostra, na maioria dos poemas, longínqua, relacionada à morte, efêmera e inexorável como o tempo, sombria em um cenário de sortilégio e sobretudo em uma atmosfera feérica, onde há a possibilidade de recuperção de histórias findas.

É nessa perspectiva que citamos um fato de extrema importância na obra apollinairiana, a imagem da mulher que povoa de forma significativa os seus poemas, sendo de três tipos: as mulheres míticas (Viviane, Salomé, Morgane...), as mulheres amadas (Annie, Marie) e as mulheres “fáceis” (Lea, Marizibil...). Assim, para apresentar o caráter falso e efêmero do amor, segundo o sujeito poético mal-amdo, Apollinaire classifica as mulheres da seguinte forma:

Déesses ou prostituées, les femmes sont d'abord des infidèles (grelottantes étoiles fausses femmes dans vos lits). Elles ne séduisent que pour mieux trahir, empoisonner, telles les colchiques. Mais qu'elles sont belles, ces ombres trompeuses! Comment échapper à la magie de leurs yeux, "couleur de Rhin", à la finesse, à l'élegance de leurs mains? (LECHERBONNIER, 1983, p.22-23) 
Observamos que Apollinaire apresenta o amor/amada de forma notadamente enganosa e falsa, seguindo um tom de acentuado lamento, provocando essa idéia de que a mulher existe apenas para trair e envenenar, como os "colchiques". Mas salienta, por meio de muitas imagens, que, apesar de todo esse caráter mortífero e dissimulado, não se pode escapar à magia, à sedução e a todos os atributos da mulher, ou seja, é a fonte que nutre o eu-lírico mal-amado, embora muitas vezes contaminada pelo logro.

Da mesma forma, o poeta brasileiro aborda a temática da mulher, pois segundo Ivan Junqueira (2003,p.280-281), “em alguns poemas de Bandeira o amor e a morte como se tangenciam, adquirindo esta a condição de mulher ora grave grave e discreta, ora terna e envolvente, ora, ainda, lúbrica ou mesmo devassa." Em face disso, vimos que a mulher está associada à morte ou vice-versa, ao engano e à lascívia, que é ora devassa e enganadora, ora pudica. Assim, semelhantemente a Apollinaire, Bandeira também expõe a mulher como santa/virgem - casta/clara, deusa do amor, Afrodite, Lilith sedutora e traiçoeira e prostituta, "prostitutas bonitas para a gente namorar". Por isso, notamos que na maioria dos poemas em que aparece a temática do amor, esse é frustrado e inacessível, mas sem a relação que muitos exegetas fazem, a uma vida pueril e a uma sublimação amorosa por parte do poeta:

tal procedimento, entretanto, não se confunde com a celebração anímica de uma projeção ideal ou irreal da figura feminina. Muito ao contrário, em sua poesia a mulher corresponderá sempre a uma entidade tangível, pulsátil e que será aceita, conforme as circunstâncias, pura ou degradada até a última baixeza.(JUNQUEIRA, 2003, p.202)

O amor aparece na obra de Bandeira como sentimento dado ao fracasso, cabendo à mulher, com toda a sua face encantatória e simulada, o papel de representar a efemeridade e a inexorabilidade do amor/ tempo que é " chama, e, depois, fumaça" ou que "no fundo é amargo e triste e dói mais do que tudo". Mas, como Apollinaire, o poeta brasileiro também mostra não resistir aos encantos daquela que envenena, como os "colchiques", pois no "Poemeto erótico", da obra aqui estudada, enumera os atributos físicos, em reticências, do corpo que lhe faz arfar de desejo: "A todo momento vejo...", “Teu corpo... a única ilha”, “ No oceano do meu desejo...” (V.19 a 20).

Nesse viés, notamos que, por conta de toda essa persistência da temática elegíacoamorosa em ambos os poemas, é no universo onírico que o eu-lírico vai tentar resgatar o 
que findou com a sucessão dos anos. Essa busca em "Crépuscule" se dá em um cosmo feérico e melancólico, em que o Arlequin retira uma estrela do céu e a maneja com os braços estendidos, enquanto um "enforcado" toca címbalos: "Ayant décroché une étoile", "Il la manie à bras tendu", "Tandis que des pieds um pendu", "Sonne en mesure les cymbales" (V.13 a 16). Assim, esse Arlequin, embora triste por sua amada Arlequine, mostra-se como um mágico que pode brincar com uma estrela, com um morto-vivo que toca címbalos, representando toda a magia, imprecisão e pesar de tal cenário crepuscular. observamos outras imagens que reforçam esse ambiente fantástico e de meio-tom, um cego que embala um bebê, pois privado da visão reafirma o caráter sombrio do poema, uma corça que passa com os seus filhotes, dando-nos a impressão de caminhar junto à passagem do tempo e de forma árdua, e um anão ar triste que observa "grandir" o "Arlequin trimégiste", sendo esse último considerado um deus da natureza, gênio da terra e do solo, colaborando para a pintura desse cenário encantatório e pesaroso: "L'aveugle berce un bel enfant", "La biche passe avec ses faons", "Le nain regarde d'un air triste", "Grandir l'arlequin trimégiste" (V. 17 a 20).

É o que ocorre em “Ao Crepúsculo”, pois toda ambientação é construída com elementos da natureza advindos de um cosmo feérico e crepuscular, possuindo uma carga simbólica notável, na medida em que a montanha apresenta-se capaz de produzir o sonho do eu-lírico e de amenizar a sua dor, ainda representa em todas as tradições a imagem da imortalidade, ou seja, a busca para eternizar o que o tempo levou consigo, o noivado precário. Vimos também outra imagem que alimenta esse cenário de nuanças e de quimeras, o mar, cuja simbologia é a dinâmica da vida, dos renascimentos, passandonos a impressão de que aquele amor findo ressuscitará do fundo de suas entranhas. Tanto o mar quanto a montanha servem de canais de comunicação entre os amantes, como em um passe de mágica, em que tais elementos personificados serviriam de cupidos que trariam de volta o amor que esvaeceu com o tempo.

Logo, nos dois poemas, o eu-lírico, apenas por meio do universo onírico crepuscular, pode reviver a história de amor com sua amada, em que "Eros e a dinâmica dos fenômenos naturais constituem essa díade salvadora, posto que nela o eu logra a transcendência de outro modo inatingível". (ROSENBAUM, 1993, p. 22)

Atentando para a tópica da efemeridade do amor e da inexorabilidade do tempo, analisamos outro poema, "Mai", como o terceiro da série de pares que seguiu tal viés, 
que no total resultou em seis, salientando a questão das recorrências motívicas nas obras aqui estudadas.

\section{Mai}

Le mai le joli mai en barque sur le Rhin

Des dames regardaient du haut de la montagne

Vous êtes si jolies mais la barque s'éloigne

Qui donc a fait pleurer les saules riverains

Or des vergers fleuris se figeaient en arrièrre

Les pétales tombés des cerisiers de mai

Sont les ongles de celle que j' ai tant aimée

Les pétales flétris sont comme ses paupières

Sur le chemin du bord du fleuve lentement

Un ours un singe menés par des tziganes

Suivaient une roulotte trînée par un âne

Tandis que s'éloignait dans les vignes rhénanes

Sur un fifre lointain un air de régiment

Le mai le joli mai a paré les ruines

De lierre de vigne vierge et de rosiers

Le vent du Rhin secoue sur le bord les osiers

Et les roseaux jaseurs et les fleurs nues des vignes

Assim, podemos dar início à análise do poema tendo como fio condutor a temática da passagem do tempo e dos sentimentos. Em "Mai", podemos dizer que o sentimento findo está caracterizado como uma desilusão amorosa ligada à estada de Guillaume na Rénanie, local em que conheceu a bela Annie Playden, governanta inglesa da casa onde trabalhou como "précepteur". Como resultado disso, nasce uma paixão do jovem poeta para com Annie, a qual, no início, corresponde a tal sentimento, mas logo, por medo de tamanha intensidade, volta para seu país. Então, vimos que se trata de um poema lírico com sentimentos pessoais e impressões que o poeta recolheu " aux bords du Rhin". Se tal situação biográfica não é apresentada explicitamente, temos alusão a uma triste história de amor findo, praticamente com o mesmo enredo de dor do poeta que sofreu do mal de amar.

Em virtude disso, partimos para a primeira estrofe de "Mai", a qual parece anunciar um idílio de primavera, dado o seu título que é retomado no primeiro verso "Le mai le joli mai". Trata-se de uma estação de ambientação florida, considerando o 
mês citado na Europa. Nessa, ainda, devemos destacar as personagens inseridas no contexto, "des dames qui regardent du haut de la montagne" (v.2), um jovem que passa de barco no Rhin (“en barque sur le Rhin”) (v.1) com uma expressão de admiração mediante a beleza das "dames", "Vous êtes si jolies mais la barque s’éloigne"(v.3).

Considerando o verso 3, vale destacar que as "dames" são inacessíveis, visto que se encontram no alto de uma montanha, e ainda,que o barco se distancia com a correnteza do rio ("la barque s'éloigne"). No verso 4, é interessante apontar que até mesmo as árvores "saules", às margens do rio, lamentam os amores impossíveis: "Qui donc a fait pleurer les saules riverains". Logo, vimos que na primeira estrofe os temas da distância e da passagem imperam, pois o rio, como já dissemos em um outro momento, segundo Heráclito, exprime a noção da passagem do tempo e da alteração dos sentimentos : "On ne se baigne jamais deux fois dans la même eau".

A imagem central do rio, com o barco sendo levado pela correnteza, indica o fluxo ininterrupto do tempo, o qual leva consigo os sentimentos; no caso de "Mai", o amor.

Nessa pespectiva, continuamos com a análise da segunda estrofe, na qual observamos explicitamente a figura da mulher amada. Nessa, notamos que a natureza é citada como um recurso para trazer de volta o que foi perdido, com toda a sua dinâmica de ciclos, e eterna sucessão de fenômenos: “ A volta do que foi perdido encontra suporte na dinâmica da natureza, mecanismo alentador para a elaboração do luto. Nela, perdas e conquistas se sucedem na multiplicidade de formas, cores, cheiros e movimentos" (ROSENBAUM,1993,p.195-196).Assim,temos imagens da natureza que traduzem a densidade da perda, como o barco que navega no rio, com os "vergers fleuris" de sua margem ficando para trás e na memória do jovem " Or des vergers fleuris se figeaient en arrière" (V.5)

O tema da passagem perdura na estrofe pois, estando as pétalas caídas das cerejeiras de maio associadas à lembrança da amada, compreendemos que a metáfora representa o ciclo das estações, como conseqüência do inexorável processo do fluir do tempo, "Les pétales tombes des cerisiers de mai", "Sont les ongles de celle que j'ai tant aimée" (V.6-7). Assim, as pétalas das flores são associadas às unhas e às pálpebras da mulher amada, não indicando mais o desabrochar da vida, a beleza no que tange o mais alto grau de sua frescura e viço, estando agora "flétris", murchas ou mortas, fazendo alusão aos ciclos da existência de todas as coisas, "Les pétales flétris sont comme ses paupières" (V.8). 
Considerando o que foi exposto, partimos para a estrofe de "Mai" que, como nas duas primeiras, apresenta imagens representativas da passagem. Nessa, observamos dois cortejos de um circo local, que caminham com esforço e lentidão, movimento exemplificado por meio dos dois alexandrinos (4-5-3//2-2-2-6), além da extensão da estrofe, que é de cinco versos, um quinteto, em contrapartida às outras três, de quatro versos, quadras: "Un ours un singe un chien menés par des tziganes”, " Suivaient une roulotte trainée par un âne" (V.10-11). Esse primeiro cortejo que, às margens do rio, caminha lentamente, dá-nos a impressão de sucessão do tempo, pois além do curso ininterrupto do Rhin como cenário, os animais são guiados por ciganos, personagens que, já de antemão, indicam constante mudança. Indivíduos de um povo nômade, que vive de ler a sorte e do artesanato, e, sobretudo, de vida incerta, sem fixar raízes em um determinado lugar. Esses, com a leitura da sorte, jogam com o tempo que passa, procurando retê-lo, unindo passado, presente e futuro.

Ainda, temos o segundo cortejo, a única referência alegre do poema, mas representado como algo que se distancia: “Tandis que s'éloignait dans les vignes rhénanes", "Sur um fifre lointain um air de régiment" (V.12-13). Assim, a música da flauta é longínqua, indicando, como na primeira estrofe, em que o barco se afasta, que a alegria, como o amor, se esvai com o tempo.

Nessa perspectiva, a última estrofe do poema segue a leitura do decurso, pois o que temos é uma paisagem construída por meio de ruínas, de antigos castelos fortificados, signos contraditórios da passagem (o que é destruído) e da permanência (o que se conserva): "Le mai le joli mai a paré les ruines" (V.14). Logo, nesse cenário de primavera, de beleza do mês de maio, ornamentado por arbustos, flores e plantas, como "lierre", "vigne", "osiers", "roseaux" e "fleurs", o que impera é a visão das ruínas, ou seja, a morte ou a distância, no caso, de um dado amor: "De lierre de vigne vierge et des rosiers" (V.15).

É importante observar que a última estrofe apresenta a evocação do vento que, como o rio, procura tudo carregar, sugerindo mais uma vez a dor da distância, e embalando com o seu potente sopro, com uma bela harmonia, em $[\mathrm{V}],[\mathrm{S}],[\mathrm{Z}],[\mathrm{F}]$, as plantas sobre as margens: “Le vent du Rhin secoue sur le bord les osiers”, “Et les roseaux jaseurs et les fleurs nues des vignes" (V.16-17) (MORHANGE-BÉGUÉ \& LARTIGUE, 1993, p.72). 
Dando continuidade à temática, analisamos o outro poema que serviu de objeto para o diálogo entre a poética bandeiriana e apollinairiana, "Enquanto morrem as rosas...".

\section{Enquanto morrem as rosas...}

Morre a tarde. Erra no ar a divina fragrância.

Fora, a mortiça luz dos crepúsculos arde.

Nas árvores, no oceano e no azul da distância

Morre a tarde...

Morrem as rosas. Minhas pálpebras se molham

No pranto das desesperanças dolorosas.

Sobre a mesa, pétala a pétala, se esfolham,

Morrem as rosas...

Morre o teu sonho?... Neste instante o pensamento

Acabrunha o meu ser como um pesar medonho.

Ah, por que temo assim? Dize: neste momento

Morre o teu sonho?...

Aqui, notamos um cenário ornamentado por flores, sendo elas metáfora da passagem do tempo e dos sentimentos, visto que, já no título, elas se apresentam em um processo de morte. Sendo assim, na primeira estrofe há todo um clima que denuncia a inexorabilidade do tempo, pois a cena se dá na tarde que morre, "Morre a tarde. Erra no ar a divina fragrância" (v.1), com uma luz, que é mortiça, prestes a apagar-se, característica do tom crepuscular, "Fora, a mortiça luz dos crepúsculos arde"(v.2). Além de a própria natureza, com suas árvores e o seu oceano, indicar, no azul da distância, que o tempo passa ininterruptamente, "Nas árvores, no oceano e no azul da distância"(v.3).

Vimos que o topos da distância daquilo que esvaeceu com o tempo, toma o centro da poesia bandeiriana, apresentando o oceano com toda a sua carga simbólica, de algo com extensão aparentemente sem limites, e ainda, segundo o Taoísmo: "o Tão está para o mundo como o mar está para os rios. Todas as águas confluem para o mar, sem enchêlo; todas as águas saem do mar, sem esvaziá-lo (CHEVALIER, 1992, p.650). Por meio dessa citação, notamos que já na primeira estrofe temos todo um cosmo que indica finitude e passagem, pois sendo o oceano/mar um receptor de todas as águas, incluindo 
as dos rios, observa-se que essa impressão longínqua e sem limites que ele causa também apresenta o fluir incessante de sua correnteza, e conseqüentemente, do decurso do tempo.

Dessa maneira, observamos no poema de Bandeira que a natureza expressa o pesar diante da passagem do tempo, pois, na segunda estrofe, as rosas continuam a ornar uma paisagem crepuscular, na qual a melancolia paira no ar devido ao pranto da distância. Nessa, as pálpebras, não mais da mulher amada, mas do eu lírico, molham-se com o pranto das desesperanças dolorosas, e as pétalas caídas sobre a mesa indicam um processo infinito de morte, reforçado pelas reticências, seja como metáfora do tempo findo ou de sentimentos não especificados: “Morrem as rosas. Minhas pálpebras se molham", "No pranto das desesperanças dolorosas", " Sobre a mesa, pétala a pétala, se esfolham", "Morrem as rosas..."(V.5,6,7e 8).

É importante mencionar que as imagens da natureza em Bandeira são bastante freqüentes, e adquirem tal valor expressivo que muitas vezes falam das dores humanas por meio de metáforas, emprestando características romântico-simbolistas a sua obra.

Como resultado do triste decurso do tempo e dos sentimentos, o poema finaliza com uma atmosfera de ruínas-morte, mas de um dado sonho, quiçá de sentimentos, momentos ou planos findos: "Morre o teu sonho?...Neste instante o pensamento" (V.9). Esse clima de finitude é ainda exemplificado por meio dos versos 10 e 11, em que um "pesar medonho" toma conta do pensamentodo eu-lírico, demonstrando que a irreversibilidade daquilo que findou chega a lhe causar paúra, "Acabrunha o meu ser como um pesar medonho.”, “Ah, por que temo assim? Dize: neste momento”. É interessante notar que, nos versos 9, 11 e 12, há expressões de dúvida, as quais são representadas por pontos de interrogação que indicam a descrença do sujeito poético na possibilidade do fim de seu sonho. Esse continua a indagar, e tenta recuperar o que foi perdido por meio da sustentação da incerteza de que o tempo não levou consigo o seu sonho: " Morre o teu sonho"...(V.12).

\section{Apollinaire e Bandeira}

Ainda seguindo o viés de uma poesia inscrita com a tinta da efemeridade dos sentimentos e da inexorabilidade do tempo, partimos para o diálogo "Enquanto morrem as rosas" e "Mai".Podemos dizer que tanto um quanto o outro abordam a questão da finitude dos sentimentos como decorrência da passagem do tempo. 
É importante mencionar que o pesar devido à inexorabilidade do tempo e, conseqüentemente, o fim dos sentimentos, é um tema caro aos poetas estudados. Por isso, a temática pode ser exemplificada por meio de uma carta de Apollinaire, datada de agosto de 1916, à Jeanne-Yves Blanc, na qual lhe confia:

je n'ai jamais désiré de quitter pour ma part le lieu où je vivais et j'ai toujours désiré que le présent quel qu'il fût perdurât. Rien ne determine plus de mélancolie chez moi que cette fuite du temps. Elle est en désaccord si formel avec mon sentiment, mon identité, qu'elle est la source même de ma poésie. (Apud DÉCAUDIN, 1993, p.81)

Observamos que a angústia do poeta está relacionada à impossibilidade de reter o tempo que passa, pois esse leva consigo o presente que sempre desejou eternizar. Apollinaire, diante de tal impotência, afirma que a fonte para a sua poesia é justamente o icontrolável fim de todas as coisas, atribuindo relevância ao seu estado melancólico de ser.

É nesse viés que o poeta pernambucano também constrói a sua obra, apontando a distância daquilo que findou em todas as esferas de sua poesia, e apresentando-se movido pela busca do que se esvaeceu com o tempo, seja na infância perdida e na saúde debilitada, seja na perda brusca dos entes queridos ou dos sentimentos vivenciados:

a partir de índices que evocam as reminiscências, Bandeira se coloca de um ponto onde avista o passado e apreendea mutabilidade dos fenômenos do mundo. Para ele importa, sobretudo, registrar como sua sensibilidade capta as transformações que destroem a pulsação dos tempos idos; seu olhar reveste os lugares e personagens do presente com um toldo amarelecido, revelação da perda e da deterioração. Os poemas que homenageiam cidades são mais do que testemunhos desse mecanismo que vê na distância histórica o declínio de uma magia (ROSENBAUM, 1993, p. 144)

É, pois, o que se vê na poética bandeiriana, um toldo amarelecido como imagem do tempo ininterrupto, deixando apenas o aspecto corrosivo do passar dos anos, determinando, como classifica Rosenbaum, uma poesia da ausência.

Notamos que tanto Bandeira quanto Apollinaire trabalham essa questão dos "tempos idos" em sua obra, por meio das reminiscências que restaram do que se foi ou de metáforas representativas dessa passagem inexorável. 
Assim, podemos dar início à análise dos poemas, tendo como fio condutor a temática da passagem do tempo e dos sentimentos. Logo, em "Mai", podemos dizer que o sentimento findo está caracterizado como uma desilusão amorosa ligada à estada de Guillaume na Rénanie, local em que conheceu a bela Annie Playden, governanta inglesa da casa onde trabalhou como "précepteur". Se tal situação biográfica não é apresentada explicitamente, temos alusão a uma triste história de amor findo, praticamente com o mesmo enredo de dor do poeta que sofreu do mal de amar.

Em virtude disso, partimos para a primeira estrofe de "Mai", a qual parece anunciar um idílio de primavera, dado o seu título e retomado no primeiro verso "Le mai le joli mai”. Estação de ambientação florida, considerando o mês citado na Europa. Nessa, ainda, devemos destacar as personagens inseridas no contexto, "des dames qui regardent du haut de la montagne" (v.2), um jovem que passa de barco no Rhin "en barque sur le Rhin" (v.1) com uma expressão de admiração mediante a beleza das "dames": "Vous êtes si jolies mais la barque s'éloigne"(v.3).

A imagem central do rio, com o barco sendo levado pela correnteza, indica o fluxo ininterrupto do tempo, o qual leva consigo os sentimentos; no caso de "Mai", o amor.

É o que ocorre em "Enquanto morrem as rosas...", pois notamos o mesmo cenário ornamentado por flores, como na primavera de "Mai", sendo essas metáfora da passagem do tempo e dos sentimentos, visto que, já no título, elas se apresentam em um processo de morte. Sendo assim, na primeira estrofe há todo um clima que denuncia a inexorabilidade do tempo, pois a cena se dá na tarde que morre, "Morre a tarde. Erra no ar a divina fragrância” (v.1), com uma luz, que é mortiça, prestes a apagar-se, característica do tom crepuscular: "Fora, a mortiça luz dos crepúsculos arde"(v.2). Além de própria natureza, com suas árvores e o seu oceano, indicar, no azul da distância, que o tempo passa ininterruptamente, "Nas árvores, no oceano e no azul da distância"(v.3).

Como Apollinaire, notamos que o topos da distância daquilo que esvaeceu com o tempo, toma o centro da poesia bandeiriana, apresentando o oceano com toda a sua carga simbólica, de algo com extensão aparentemente sem limites.

Continuamos com a análise da segunda estrofe, a qual em "Mai" observamos explicitamente a figura da mulher amada. Nessa, notamos que a natureza é citada como um recurso para trazer de volta o que foi perdido, com toda a sua dinâmica de ciclos, e eterna sucessão de fenômenos. 
O tema da passagem perdura na estrofe, pois estando as pétalas caídas das cerejeiras de maio associadas à lembrança da amada, compreendemos que a metáfora representa o ciclo das estações, como consequiência, do inexorável processo do fluir do tempo.

Da mesma maneira, observamos no poema de Bandeira que a natureza expressa o pesar diante da passagem do tempo, pois na segunda estrofe, as rosas continuam a ornar uma paisagem crepuscular, na qual a melancolia paira no ar devido ao pranto da distância. Nessa, as pálpebras, não mais da mulher amada, mas do eu-lírico, molham-se com o pranto das desesperanças dolorosas, e as pétalas caídas como, em Apollinaire, aqui sobre a mesa, indicam um processo infinito de morte, reforçado pelas reticências, seja como metáfora do tempo findo ou de sentimentos não especificados.

É importante mencionar que as imagens da natureza em Bandeira são bastante frequientes, adquirem de tal forma valor expressivo, que muitas vezes falam das dores humanas por meio de metáforas, emprestam características romântico-simbolista a sua obra.

(...) as imagens da natureza adquirem valor expressivo em sua confluência com processos subjetivos. Esse caráter romântico-simbolista da obra de Bandeira não deve ser subestimado. Embora não se possa falar de uma visão panteísta, a sensibilidade ao"ser"da natureza ocupa um espaço significativo no lirismo bandeiriano (ROSENBAUM, 1993, p.186)

Nessa perspectiva, a última estrofe de "Mai" segue também a leitura do decurso, pois o que temos é uma paisagem construída por meio de ruínas, de antigos castelos fortificados, signos contraditórios da passagem (o que é destruído) e da permanência (o que se conserva): "Le mai le joli mai a paré les ruines" (V.14). Logo, nesse cenário de primavera, de beleza do mês de maio, ornamentado por arbustos, flores e plantas, como "lierre", "vigne”, “osiers", "roseaux" e "fleurs", o que impera é a visão das ruínas, ou seja, a morte ou a distância, no caso, de um dado amor.

No mesmo sentido Bandeira finaliza o seu poema, pois, na última estrofe, também apresenta uma atmosfera de ruínas-morte, mas nesse, de um dado sonho, quiçá de sentimentos, momentos ou planos findos: "Morre o teu sonho?...Neste instante o pensamento" (V.9). Esse clima de finitude é ainda exemplificado por meio dos versos 10 e 11, em que um "pesar medonho" toma conta do pensamentodo eu-lírico, demonstrando que a irreversibilidade daquilo que findou chega a lhe causar paúra, 
“Acabrunha o meu ser como um pesar medonho.”, “Ah, por que temo assim? Dize: neste momento". É interessante notar que, nos versos 9, 11 e 12, há expressões de dúvida, as quais são representadas por pontos de interrogação que indicam a descrença do sujeito poético mediante na possibilidade do fim de seu sonho. Esse continua a indagar, e tenta recuperar o que foi perdido sustentando a incerteza de que o tempo não levou consigo o seu sonho: "Morre o teu sonho"...(V.12).

Enfim, nesses poemas encontramos o lamento pelos sentimentos findos, a resignação mediante a passagem do tempo e a submissão do eu-lírico às reminiscências dolorosas. 


\section{4 - A Epifania e o Ubi Sunt?}

Corroborando a temática do "tempo não-reconciliado", tomamos para estudo os poemas "Volta" e "Rosemonde" considerando que seguem as características da tópica “A epifania e o Ubi Sunt?”. Nesses, vimos a questão da evanescência de todas as coisas, como a mulher amada (Ubi Sunt?) e a visão súbita (epifania) daquela que havia se perdido com o tempo.

Assim, iniciamos com o poema "Rosemonde", de 1912, que apresenta o reencontro do eu-lírico com o seu amor que havia sido levado pelo decurso do tempo.

\section{Rosemonde}

Longtemps au pied du perron de

La Maison où entra la dame

Que j' avais suivie pendant deux

Bonnes heures à Amsterdam

Mes doigts jetèrent des baisers

Mais le canal était désert

Le quai aussi et nul ne vit

Comment mes baisers retrouvèrent

Celle à qui j'ai donné ma vie

Un jour pendant plus de deux heures

Je la surnommai Rosemonde

Voulant pouvoir me rappeler

Sa bouche fleurie en Hollande

Puis lentement je m'en allai

Pour quêter la Rose du Monde

Esse reencontro se dá como uma verdadeira aparição, visto que a mulher amada surge no pé da escadaria ("perron") de uma casa, depois de duas horas de procura do sujeito poético em Amsterdan, tempo prolongado pelo adjetivo "bonnes" e pelo vocábulo "longtemps", que ampliam a idéia de distância do objeto amado. Diante dessa visão epifânica, o eu-lírico parece ter verdadeiramente reencontrado o seu amor e chega mesmo a lhe jogar beijos: "Longtemps au pied du perron de", "La Maison où entra la dame”, "Que j'avais suivie pendant deux", "Bonnes heures à Amsterdam”, "Mes doigts jetèrent des baisers" (V. 1 a 5). Logo, essa visão da mulher amada não passa de uma 
imagem súbita, demonstrando toda a fugacidade dos seres e conseqüentemente do amor, confirmado na estrofe seguinte.

A imagem da mulher amada some como uma chama que se apaga, simbolizando apenas o instante feliz da visão ou "o momento de uma aparição". Dessa forma, da imagem repentina e fugaz (epifania) restam apenas o canal e o cais desertos, além de não haver ninguém para testemunhar os beijos que não chegam àquela por quem o eulírico dá a vida: " Mais le canal était désert", "Le quai aussi et nul ne vit", "Comment mes baisers retrouvèrent”, “ Celle à qui j’ai donné ma vie” (V. 6 a 9). Assim, essa imagem do vazio (désert/nul) simboliza, mesmo que implicitamente, a questão do " $U b i$ Sunt?" como indagação a respeito da ausência da mulher amada, tendo o silêncio como resposta. Desse modo, à pergunta “Ubi Sunt?" que ficou como resposta ao caráter instantâneo da imagem epifânica (no pé da escadaria), temos a repetição da idéia dos versos 3 e 4, a procura pela mulher amada durante mais de duas horas, ou seja, a volta à questão da perda: "Un jour pendant plus de deux heures" (V. 10).

Nessa perspectiva, observamos que na última estrofe o eu-lírico tenta dar resposta à angustiante pergunta "Ubi Sunt?" por meio do recurso mnemônico, evocando a imagem daquela que nomeia como Rosemonde, visando lembrar de sua "boca florida", no próprio país característico por suas flores, para quiçá apaziguar tamanha dor da falta: "Je la surnommai Rosemonde", "Voulant pouvoir me rappeler", "Sa bouche fleurie em Hollande" (V. 11 a 13). Diante disso, não podemos deixar de mencionar o caráter simbólico da (rosa/Rosemonde/Rose du Monde) no poema, "remontando ao mito de Adônis, o amado de Afrodite (Vênus) de cujo sangue teriam brotado as primeiras rosas vermelhas. Essas se tornaram assim o símbolo do renascimento e do amor que sobrevive à morte" (BIEDERMANN, 1993, p.329).

O caráter elegíaco-amoroso é acentuado nos últimos versos, na medida em que a "rosa", símbolo do renascimento e do amor que sobrevive à morte, serve como resposta ou consolo à questão pesarosa "Ubi Sunt?" a respeito da falta e à imagem repentina da mulher amada. Então o registro simbólico funciona como alternativa para reconstruir ou reencontrar o amor perdido, permanecendo a "rosa" apenas como lembrança que ameniza a dor da ausência. Mas logo esse valor simbólico de restauração do amor é desfeito, pois, apesar dessa associação e volta da mulher amada, mesmo que de forma instantânea (visão epifânica) e mítica (a rosa como símbolo), o eu-lírico volta para a realidade, segue seu caminho lentamente para aceitar e deixar definitivamente a "Rose 
du Monde": "Puis lentement je m'en allai", "Pour quêter la Rose du Monde" (V.14 e 15). Desse modo, o poema finaliza com a questão do distanciamento do outro, voltando a mulher/rose a sua condição primeira de recordação, circundando a pergunta "Ubi Sunt?” em relação àquela que "ante nos en mundo fuere?".

Dando seqüência, partimos para o poema de Manuel Bandeira, "Volta".

\section{Volta}

Enfim te vejo. Enfim no teu

Repousa o meu olhar cansado.

Quanto o turvou e escureceu

Sem apagar teu vulto amado!

Porém já tudo se perdeu

No olvido imenso do passado:

Pois que és feliz, feliz sou eu.

Enfim te vejo!

Embora morra incontentado,

Bendigo o amor que Deus me deu.

Bendigo-o como um dom sagrado.

Como o só bem que há confortado

Um coração que a dor venceu!

Enfim te vejo!

Notamos aqui que o eu-poético finalmente revê a sua amada, repousando o seu olhar cansado naquela por quem experimentou o pranto amargo, não apagando, apesar de tamanha dor, as suas reminiscências: "Enfim te vejo. Enfim no teu", "Repousa o meu olhar cansado.", "Quanto o turvou e escureceu", "O pranto amargo que correu", "Sem apagar teu vulto amado!” (V.1 a 5). Assim, notamos que a ausência da mulher amada é preenchida por sua chegada repentina - "Enfim te vejo" - como uma visão abrupta (epifania), que volta, de forma breve e imaginária.

Mas essa "volta" se dá realmente como uma aparição, visto que na estrofe seguinte há a confirmação de que tudo se perdeu no passado, restando implicitamente a questão "Ubi Sunt?" diante daquela que amou: "Porém já tudo se perdeu", "No olvido imenso do passado" (V. 6 e 7). No entanto, temos novamente a visão súbita, na medida em que o eu-lírico, apesar da triste perda da amada, mostra-se feliz, devido a mais um 
instante de revelação da mesma: "Pois que és feliz, feliz sou.", "Enfim te vejo!" (V. 8 e 9). Desse modo, é importante destacar a repetição do verso "Enfim te vejo!", agora exclamativo, reforçando a idéia de surpresa e brevidade de tal aparição. Nessa perspectiva, observamos que esse retorno acontece de forma instantânea, como flashes de visão, primeiro se mostrando para em seguida se apagar, restando sempre, após o êxtase fugaz, a dor da ausência.

$\mathrm{Na}$ última estrofe, o eu-lírico confirma a falta do outro/amada, e, como resultado disso, citamos um trecho de Rosenbaum (1993, p.83) que explicita tal idéia: "a ausência domina o espaço poético e faz com que esse outro se presentifique exatamente por não existir mais". Logo, o eu-poético apresenta toda a sua condição de mal-amado, salientando que somente o amor que Deus lhe deu pode confortar seu coração dilacerado pela dor da ausência: "Embora morra incontentado, ", "Bendigo o amor que Deus me deu.", "Bendigo-o como um dom sagrado.", "Como o só bem há confortado", “Um coração que a dor venceu!" (V. 10 a 14).

Para apaziguar a angústia da ausência, o que foi perdido ressurge no espaço literário, mesmo que de forma breve (epifânica), pois o último verso "Enfim te vejo!" parece mais uma miragem consoladora para o eu-lírico tentar eternizar aquilo que foi levado com o decurso do tempo. Ademais, não podemos deixar de mencionar que essa "volta", nome dado ao poema, ou retorno daquele amor que havia se perdido, não acontece verdadeiramente, representa apenas a imagem de recusa dessa perda amorosa, ou seja, uma visão súbita em um texto breve que serve como o único recurso capaz de amenizar o pesar do sujeito poético mal-amado.

\section{Apollinaire e Bandeira}

Dando continuidade, abordamos a temática “A epifania e o Ubi Sunt?” em ambos os poemas, "Rosemonde" e "Volta". O diálogo se deu na medida em que observamos, tanto em um quanto no outro, a questão da ausência da amada que se esvaiu com o tempo “Ubi Sunt?", mas concomitantemente o seu reencontro como uma visão que lhe traz, mesmo que de forma fugaz, a felicidade perdida (epifania).

Iniciamos pela análise formal do poema "Rosemonde", que apresenta três estrofes de cinco versos, quintilhas, em sua maioria heptassílabos. Ele é constituído por 15 versos no total, os quais não finalizam juntamente com o segmento sintático, sendo 
construídos por meio do encadeamento, ou pelo termo francês mais conhecido, "enjambement":

Longtemps au pied du perron de

La maison où entra la dame

Que j'avais suivie pendant deux

Bonnes heures à Amsterdam

De forma semelhante, o poema "Volta" contém três estrofes, mas apenas a primeira classificada como quintilha, sendo as outras duas uma quadra e uma sextilha. O poema, no total, é constituído por 15 versos, embora menos uniforme quanto à medida ou extensão da linha poética, pois temos ora heptassílabos e octassílabos, ora quartetos. Semelhante à "Rosemonde", a pausa final dos versos não coincide com a pausa respiratória, eles são construídos pelo recurso poético "enjambement”:

Porém já tudo se perdeu

No olvido imenso do passado:

Pois que és feliz, feliz sou eu.

Após a análise dos aspectos formais dos poemas, partimos para o estudo da temática propriamente dita "A epifania e o Ubi sunt?". Para isso nos reportamos às literaturas mais antigas que já tinham a questão da ausência - "Ubi sunt?" - como tema:

mas esse lugar rotulado da literatura - que está em trechos bíblicos de Salomão e Isaias, em Boécio ("De consolatione philosophiae"), em Jacopone de Todi (em seu "Rhythmus contemplu mundi"), em Eustache Deschamps, em Villon, nas famosas coplas de Jorge Manrique, além de Von Platen, Goethe e outros - é apropriado por Bandira e recriado em diversas tonalidades. Verifica-se um aproveitamento bastante original do tema, tornando-se parte fundamental dessa poesia que se arvora em evocar as ausências. (ROSENBAUM, 1993, p.97) 
É importante destacar que na história da literatura esse tema sempre esteve presente e tanto Bandeira quanto Apollinaire se apropriam dessa tópica, cada um à sua maneira, recriando, mesmo que de forma implícita, a questão do "Ubi sunt?" vinculada à morte (nem sempre física) ou à perda do objeto amado.

A epifania nos poemas completa a idéia de ausência, pois em ambos a súbita visão da mulher amada reforça o caráter fugaz dessa poesia, permanecendo apenas por "um momento de aparição", sempre voltando para a indagação referente à falta - Ubi sunt?”. Desse modo, em "Rosemonde", o eu-lírico, como em uma miragem que não dura mais do que segundos, vê a sua amada no pé da escadaria. Ele enfatiza o esforço que teve durante duas "bonnes heures" para reencontrar o seu amor, que entra surpreendentemente na casa, como uma visão inesperada: "Longtemps au pied du perron de", "La Maison où entra la dame", "Que j'avais suivie pendant deux", "Bonnes heures à Amsterdam", "Mes doigs jetèrent des baisers" (V. 1 a 5).

É o que ocorre em "Volta", pois o eu-lírico finalmente revê a sua amada, repousando o seu olhar cansado naquela por quem experimentou o pranto amargo, não apagando, apesar de tamanha dor, as suas reminiscências: "Enfim te vejo. Enfim no teu", "Repousa o meu olhar cansado.", "Quanto o turvou e escureceu”, "O pranto amargo que correu”, "Sem apagar teu vulto amado!” (V. 1 a 5). Como Apollinaire, a ausência da mulher é preenchida por sua chegada repentina - "Enfim te vejo" - como uma visão abrupta (epifania) que volta de forma breve.

Observamos que em ambos os poemas a mulher retorna como uma aparição, ou seja, transformando os pequenos feitos e experiências da vida humana (a perda de um dado amor) em instantes de revelação e epifania:

neste momento, aborda o impacto dessa visão iluminada da mulher implica a discussão do conceito de "epifania" enquanto expressão de um "êxtase estético". Etimologicamente, "epifania" vem de epiphaino, ou seja, fazer aparecer, mostrar, fazer conhecer. No texto "Uma Noção Joyceana", Umberto Eco rastreia as relações entre epifania em Joyce e a tradição decadentista, estabelecendo paralelos entre o escritor irlandês (e seu herói Stephen Hero) e a obra Il Fuoco, de Gabriele D'Annunzio. Eco mostra a epifania como "o momento de uma aparição [grifo seu] (quando a realidade aparece, se revela, prestes a ser traduzida em imagem poética, ou melhor, quando ela já 
aparece como imagem poética). (ECO, apud ROSENBAUM, 1993, p. 15

Mas essa súbita manifestação da mulher ou retorno instantâneo logo volta para a sua condição primeira, a ausência - "Ubi sunt?", pois em "Rosemonde" os beijos que o eu-lírico joga já não encontram o seu amor. Além de apresentar uma cena que confirma a perda daquela a quem deu sua vida, o vazio do deserto, do cais e a inexistência de pessoas, o que nos direciona para a imagem que se desfez, não havendo ninguém como testemunha dessa aparição, inclusive ele.

Da mesma forma, no poema de Bandeira a volta da mulher amada se dá também como uma aparição, visto que na segunda estrofe há a confirmação de que tudo se perdeu no passado, restando implicitamente a indagação - "Ubi sunt?” mediante aquela que amou: "Porém já tudo se perdeu", "No olvido imenso do passado:" (V. 6 e 7). No entanto, temos novamente a visão súbita, na medida em que o eu-lírico, apesar da triste perda da amada, mostra-se feliz, devido a mais um instante de revelação da mesma: "Pois que és feliz, feliz sou eu.", "Enfim te vejo!" (V. 8 e 9). Desse modo, é importante destacar a repetição do verso "Enfim te vejo!", agora exclamativo, reforçando a idéia de surpresa e brevidade de tal aparição. Nessa perspectiva, observamos que esse retorno acontece de forma instantânea, como "flashs" de visão, primeiro se mostrando para em seguida se apagar, restando sempre após o êxtase fugaz, a dor da ausência ou a pergunta angustiante "Ubi sunt?".

Notamos que ambos os poemas têm a ausência - "Ubi sunt?" como leitmotiv, estando na linguagem poética a salvação para a aflição eterna da figura do mal-amado, a perda de sua amada, tentando por meio do ato sublimatório (a escrita), reconquistar o que ficou no passado:

tratando-se, em Bandeira, [e aqui inserimos Apollinaire], de uma poesia que referencializa, na linguagem, a questão da falta - ao mesmo tempo em que é movida pela necessidade de elaborá-la e encontrar caminhos para existir entre as perdas - ,a pergunta "ubi sunt qui ante nos en mundo fuere?" essencializa esse veio que sulca as obras (sic). É uma questão que demanda uma resposta, que busca, na objetivação da linguagem, um sentido apaziguador. (ROSENBAUM, 1993, p. 97) 
Então, a ausência do outro é confirmada na última estrofe dos poemas, visto que o eu-lírico em "Rosemonde" tenta dar resposta à angustiante pergunta "Ubi sunt?" por meio do recurso mnemônico, evocando a imagem daquela que nomeia como Rosemonde, visando lembrar de sua "boca florida" na "Hollande", para quiçá amenizar tamanha dor da falta: "Je la surnommai Rosemonde", "Voulant pouvoir me rappeler", "Sa bouche fluerie en Hollande" (V. 11 a 13). Assim, o caráter elegíaco-amoroso é acentuado nos últimos versos, na medida que a "rosa", símbolo do renascimento e do amor que sobrevive à morte, serve como resposta para a questão pesarosa “Ubi sunt?" à respeito da falta e à imagem repentina da mulher amada.

Então o registro simbólico funciona como alternativa para reconstruir ou reencontrar o amor perdido, permanecendo a "rosa" apenas como lembrança que ameniza a dor da ausência. Mas logo esse valor simbólico de restauração do amor é eliminado, pois, apesar dessa associação e volta da mulher amada, mesmo que de forma instantânea (visão epifânica) e mítica (a rosa como símbolo), o eu-lírico retorna para a realidade, segue seu caminho lentamente para aceitar a sua condição de mal-amdo e deixar definitivamente a "Rose du Monde": "Puis lentement je m'en allai", "Pour quêter la Rose du Monde" (V. 14 e 15).Desse modo, o poema finaliza com a questão do distanciamento do outro, voltando a mulher a sua condição primeira de recordação, circundando mesmo que indiretamente a pergunta "Ubi sunt?".

De forma similar, o eu-lírico de "Volta" tenta recuperar por meio do tom evocatório do poema e do amor dado por Deus, a sua amada, como se isso fosse a única lembrança que permaneceu após a perda. Nessa perspectiva, o eu-poético apresenta toda a sua condição de mal-amado, salientando que somente o amor que Deus lhe deu (sentimento de recordação/sagrado) pode confortar seu coração dilacerado pela distância de sua amada: "Embora morra incontentado,", "Bendigo o amor que Deus me deu.", "Bendigo-o como um dom sagrado.", "Como o só bem que há confortado", "Um coração que a dor venceu!" (V. 11 a 14). Como em Apollinaire, o sujeito poético encerra com a indagação subentendida "Ubi sunt?, pois a aparição do último verso "Enfim te vejo!", como já denominamos aqui de visão súbita (epifânica), desaparece em questão de segundos, permanecendo apenas o lamento pela distância da amada e a pergunta sem resposta, cujo silêncio já é representativo de sua própria ausência: 
el efecto máximo de este esquema (Ubi sunt?) se dá cuando no se contesta a la pregunta del "adonde" de um modo explícito, y la respuesta queda sobrentendida en el silencio. Es dar la callada por respuesta. Ese silencio traduce simbolicamente el inmenso "no ser" de la muerte, en el "no ser" de ninguna voz respondiente. Todos han caido en el silencio. (OLIVEIRA, apud ROSENBAUM, 1993, p.101)

Em resumo, "Rosemonde" e "Volta" são poemas que apresentam a ausência "Ubi sunt" como tema central, havendo no eu-lírico uma eterna busca pela reaproximação de seu objeto amado, mesmo que isso se dê de forma súbita, como uma aparição que logo se esvai "epifania".

\section{5 - 0 Gozo a partir da contemplação}

Por meio desse subtema, pudemos abordar a questão da existência do amor platônico no eu-lírico mal-amado de "1909", tal como foi visto acima na poesia trovadoresca que se dirige a um objeto intocável.

\section{9}

La dame avait une robe

En ottoman violine

Et sa tunique brodée d'or

Était composée de deux panneaux

S'attachant sur l'épaule

Les yeux dansants comme des anges

Elle riait elle riait

Elle avait un visage aux couleurs de France

Les yeux bleus les dents blanches et les lèvres très rouges

Elle avait un visage aux couleurs de France

Elle était décolletée en rond

Et coiffée à la Récamier

Avec de beaux bras nus 
N'entendra-t-on jamais sonner minuit

La dame en robe d'ottoman violine

Et en tunique brodée d'or

Décolletée en rond

Promenait ses boucles

Son bandeau d'or

Et traînait ses petits souliers à boucles

Elle était si belle

Que tu n'aurais pas osé l'aimer

J'aimais les femmes atroces dans les quartiers énormes

Où naissaient chaque jour quelques êtres nouveaux

Le fer était leur sang la flamme leur cerveau

J'aimais j'aimais le peuple habile des machines

Le luxe et la beauté ne sont que son écume

Cette femme était si belle

Qu'elle me faisait peur

Semelhante à leitura platônica do amor, observamos um outro aspecto que vai ao encontro dessa visão contemplativa, a "estética parnasiana do erotismo (a imagem da mulher-estátua)"segundo Affonso Romano de Sant'Anna. Logo, nessa estética, a mulher se mostra longínqua e inacessível, o que é observado no poema de Apollinaire.

Já na primeira estrofe notamos traços dessa mulher inacessível, pois o eu-lírico a descreve com tamanha beleza que a sua própria vestimenta a caracteriza como um ser diferente dos humanos, provavelmente uma mistura de deusa, santa e anjo. Assim, ela é descrita com um vestido violeta, uma túnica e uma bandana bordados a ouro, material oneroso que de antemão indica não se tratar de pessoa comum. Também é importante ressaltar que a túnica faz parte de um antigo vestuário, longo e ajustado ao corpo usado por muitas entidades e divindades, o que atesta mais uma vez o caráter sagrado dessa mulher: "La dame avait une robe", "Em ottoman violione”, "Et sa tunique brodée d'or", “Était composée de deux panneaux", "S'attachant sur l'épaule” (V. 1 a 5).

A imagem sacralizada é confirmada na segunda estrofe, posto que os olhos azuis da mulher dançam como anjos, seus lábios são extremamente vermelhos e seus dentes brancos, dando-nos a impressão de estarmos diante de um anjo ou de uma santa, em um mundo pueril com toda a sua alvura, ou com seu corpo alvirrósseo, como no dizer dos poetas parnasianos. 
Outrossim, notamos um outro aspecto relacionado ao subtema e que é destacado por Affonso Romano de Sant'Anna sobre a tensão (desejo/interdição) presente na “mulher-estátua” da estética parnasiana. Essa tensão é observada em "1909”, na medida em que a "dame" usa um vestido de cor um tanto quanto provocante, violeta púrpura, passando-nos a imagem de mulher que desperta desejo. Assim, segue o conflito de sentimentos, pois os belos braços dessa mulher se mostram nus, sem o véu do pudor, como era esperado:"La dame avait une robe", "En ottoman violine", "Avec de beaux bras nus" (V. 1, 2 e 13). Simultaneamete, essa mesma "dame" tem olhos azuis que dançam como anjos, dentes brancos e lábios bastante vermelhos, descrição típica de uma virgem alva. Ainda, essa mulher longínqua apresenta um degolo deveras respeitoso, "en rond", com o qual se resguardam os seios, e também uma outra característica que sugere um mundo pueril e jovial, suas fivelas enfeitando seus sapatos, talvez seus cabelos, visto que o verso 18 "Promenait ses boucles", não determina a parte do corpo adornada: "Elle était décolletée en rond", "Et traînait ses petits souliers à boucles" (V.11 e 20), o que confirma tal tensão, pois a mulher é ora pudica, ora provocante com toda a sua beleza tentadora.

Ao se falar de mulher-estátua na estética parnasiana, não podemos deixar de mencionar a origem do termo: o seu surgimento se dá como conseqüência do positivismo, enfatizando a função mediadora da esposa e incentivando o culto da santa mãe. Logo, o eu-lírico segue tal tendência, pois a mulher é de tal forma exaltada que, na realidade, é como se estivesse em um pedestal para ser adorada, sua beleza ultrapassa os limites a tal ponto que ninguém ousaria amá-la, ou seja, ela existe unicamente para ser contemplada como uma santa: "Elle était si belle", "Quelle me faisait peur.” (V. 28 e 29).

Diante desse cenário de contemplação e santificação da mulher amada, também observamos que o eu-lírico afirma que em um determinado momento de sua vida gostou de mulheres cruéis das grandes cidades. Nessas, diz ainda que nasciam todos os tipos de pessoas, com sangue de ferro e cérebro de chama. Desse modo, o que observamos é um eu-lírico cansado dos sortilégios e atrocidades dessas mulheres, chegando mesmo a querer mudar tal situação por meio de sua idealização e santificação, criando para si a imagem pueril para ser apenas contemplada, para talvez não provar mais do gosto amargo do fel dessas "Lilith dos grandes centros": "J'aimais les femmes atroces dans les quartiers énormes", "Où naissaient chaque jour quelques êtres nouveaux", "Le fer était leur sang la flamme leur cerveau" (V. 23 a 25). Em se tratando do cansaço do sujeito poético diante de 
tais mulheres, também afirma que já gostou do povo hábil das grandes máquinas, ou seja, daqueles que estavam no domínio das descobertas na sociedade industrial, mas que hoje vê somente vaidade e futilidade com suas mazelas, sua parte desprezível, posto que o vocábulo usado no poema "écume" no sentido figurado, denota "Partie vile et méprisable des grandes villes.”(LAROUSSE, 1984, p.135).

O eu lírico cria todo um universo idealizado, no qual a sua amada não passa de uma virgem/santa para ser contemplada, em um cenário onde não se escuta jamais soar a meia noite, horário que talvez acabasse com todo o seu sonho pueril: "N'entendra-t-on jamais sonner minuit" (v.14).

Prosseguindo com a análise desse subtema, notamos no poema "Confissão" de Bandeira, a presença do amor contemplativo segundo a estética parnasiana da "mulherestátua" :

\section{Confissão}

Se não a vejo e o espírito a afigura,

Cresce este meu desejo de hora em hora...

Cuido dizer-lhe o amor que me tortura,

$\mathrm{O}$ amor que a exalta e a pede e a chama e a implora.

Cuido contar-lhe o mal, pedir-lhe a cura...

Abrir-lhe o incerto coração que chora,

Mostrar-lhe o fundo intacto de ternura,

Agora embravecida e mansa agora...

E é num arroubo em que a alma desfalece

De sonhá-la prendada e casta e clara,

Que eu, em minha miséria, absorto a aguardo...

Mas ela chega, e toda me parece

Tão acima de mim...tão linda e rara...

Que hesito, balbucio e me acobardo.

Aqui, o eu lírico enaltece a sua amada, colocando-a em uma posição superior à dele, sobre um pedestal para ser contemplada, contando na primeira estrofe toda a angústia por não tê-la em seus braços. Por isso, o amor que sente é visto como um ritual sagrado, exaltando a mulher amada acima de tudo, não vendo-a, mas afigurando-a em seu espírito, ou seja, adorando-a como uma imagem santificada - a "mulher-estátua" do parnasianismo. 
O eu lírico aborda a questão da santidade e da alvura da mulher amada, pois cita que sua alma esmorece quando sonha com ela "prendada e casta e clara", e faz referência à associação com o branco marmóreo das estátuas clássicas, o que foi retomado pelos parnasianos. Em "Confissão", verificamos que o vocábulo "casta" direciona os olhares do amante para a pureza do corpo e do meio no qual está inserida a sua amada, elevando-a com todo pudor que mais parece estarmos mediante uma figura canonizada. O eu-lírico, com a palavra "prendada", ainda organiza um cosmo em que a mulher possui prendas ou qualidades apreciáveis, sendo não somente um ideal de beleza feminina, como também, um ideal de mulher: “E é num arroubo em que a alma desfalece/ De sonhá-la prendada e casta e clara,/ Que eu, em minha miséria, absorto a aguardo..." (v. 9 a 11). Esse último verso mostra-nos todo o pesar que o eu-lírico sente diante desse amor que é alheio a interesses ou gozos materiais, pois, na sua miséria, embevecido pela imagem que mais se assemelha a uma santa, aguarda, não importando quanto tempo, a sua amada, o que é indicado pelas reticências.

Vale destacar um outro aspecto que diz respeito ao subtema analisado, a tensão (desejo e interdição) presente na imagem da "mulher-estátua" da estética parnasiana. Logo, essa questão pode ser exemplificada por meio dos versos 2 e 10, em "Confissão", “ Cresce este meu desejo de hora em hora.../ De sonhá-la prendada e casta e clara,", os quais confirmam essa tensão de sentimentos, ora desejando ardentemente ora prezando pela castidade da amada, sem maculá-la. Esse conflito é característico da mulher-estátua, visto que ela é polissêmica. Ela apresenta diversos significados míticos e ideológicos, seja no paganismo, com a Vênus e a Afrodite, seja no cristianismo, com a representação de forma direta ou indireta da Virgem Maria. Dessa dubiedade surge uma problemática simbólica enraizada no homem cristão ocidental: o prazer amoroso sufocado pelo remorso do pecado segundo a ideologia judaico-cristã, o pecado e a virtude.

A mulher amada apresenta uma beleza rara, estando acima do sujeito poético, e confirmando a sua posição sobre um supedâneo: "Mas ela chega, e toda me parece/ Tão acima de mim... tão linda e rara..." (v.12 e 13). Assim, o eu-lírico irresoluto ao ver a sua amada, diante de surpreendente beleza, chega a balbuciar e se acovardar, corroborando a concepção da estética parnasiana da mulher-estátua que existe unicamente para ser adorada, causando temor naquele que a cultua como uma santa e alimentando um desejo que cresce de hora em hora: "Que hesito, balbucio e me acobardo" (v.14). 


\section{Apollinaire e Bandeira}

Prosseguindo com a análise desse subtema, notamos nos poemas "1909" e "Confissão" a existência do amor contemplativo, caracterizando a dor do eu-lírico, que busca incessantemente recuperar o seu amor perdido, estando esse sempre inatingível ou não-reconciliado.

Semelhante a essa visão contemplativa do amor, observamos um outro aspecto relacionado com o topos - a inacessibilidade da mulher amada- " a estética parnasiana do erotismo (imagem da mulher-estátua)". Desse modo, é importante ressaltar que essa leitura segue um viés temático caro ao Parnasianismo, a imagem longínqua da mulher, e não a forma propriamente dita dos poemas, embora "Confissão" seja um soneto composto por rimas em todos os seus versos. Nesse sentido, notamos que esse amor é puramente platônico, por isso tortura o sujeito poético que pede, chama e implora à sua amada a reciprocidade de tal sentimento: "Se não a vejo e o espírito a afigura,/ Cresce este meu desejo de hora em hora.../ Cuido dizer-lhe o amor que me tortura,/ O amor que a exalta e a pede e a chama e a implora". (v.1, 2, 3)

Notamos que o eu-lírico de "1909" descreve a sua amada como um ser de beleza inefável, que a sua própria indumentária caracteriza um indivíduo sacralizado, quiçá uma mistura de deusa, santa e anjo. Logo, ela é descrita com um vestido violeta, uma túnica e uma bandana bordados de ouro, material oneroso que nos indica, a priori, um sujeito poético que caracteriza sua amada não como uma mulher comum.

E, dessa maneira, também enaltecendo a sua amada, colocando-a em uma posição distante, sobre um pedestal para ser contemplada, que o eu-lírico bandeiriano conta, na primeira estrofe, toda a sua angústia por tê-la longe de seus braços. Por isso, o amor que sente é visto como um ritual sagrado, exaltando a mulher acima de tudo, não a vendo, mas a afigurando em seu espírito, ou seja, adorando-a como uma imagem santificada - a mulher-estátua do Parnasianismo.

Vimos que tanto Bandeira quanto Apollinaire constroem a imagem da mulher por meio da adoração daquele que ama para com o ser amado, restando apenas o gozo a partir da contemplação. Sendo assim, é importante mencionar um trecho de Affonso Romano de Sant'Anna a respeito de tal temática: 
com a cristalização do movimento parnasiano em torno de 1880, começa a surgir em nossa poesia, reincidentemente, a imagem da mulher-estátua. Descrita em cima de um pedestral, ela é a Vênus e a Afrodite greco-romanas seduzindo o homem. Seu corpo alvirrósseo, no dizer dos poetas, surge das ondas cercado de espumas e irradiações de desejo. Vem nua e fria, mas latejando pulsões inconscientes do escritor. (SANT'ANNA, 1984, p.62)

É o que observamos nos poemas, visto que as mulheres estão acima do eu-lírico como deusas greco-romanas a serem adoradas, seduzindo-o mesmo que à distância. Logo, podemos dizer que se trata do conceito de mulher ideal, como se caracterizava no esplendor do Parnasianismo, com as diferentes peças de escultura que se faziam de Vênus como ideal de beleza feminina.

Essa figura da mulher-estátua pode ainda ser representada por meio de mais um exemplo de sacralização feito em "1909", a descrição da amada com seus olhos azuis que dançam como anjos, seus dentes brancos e seus lábios extremamente vermelhos. Assim, temos a impressão de estarmos diante de um anjo / santa, com seus sapatos de fivela, em um mundo pudico, com toda a sua alvura ou seu corpo alvirrósseo, como no dizer dos poetas parnasianos.

O sujeito poético bandeiriano, da mesma forma, aborda a questão da santidade e da alvura da mulher amada, pois afirma que sua alma esmorece quando sonha com ela "prendada e casta e clara", e faz referência à associação com o branco marmóreo das estátuas clássicas, o que também foi retomado pelos parnasianos. Também em "Confissão" verificamos que o vocábulo "casta" direciona os olhares do amante para a pureza do corpo e do meio no qual está inserida a sua amada, elevando-a com todo pudor que mais parece estarmos, como no poema de Apollinaire, mediante uma figura canonizada.

Vale destacar um outro aspecto que diz respeito ao subtema analisado, a tensão (desejo e interdição) destacada por Affonso Romano de Sant'Anna na imagem "mulherestátua" da estética parnasiana. Esse conflito é característico da mulher-estátua, visto que ela é polissêmica. Ela apresenta diversos significados míticos e ideológicos, seja no 
paganismo, a Vênus e a Afrodite seja no cristianismo a representação de forma direta ou indireta da Virgem Maria.

No poema de Apollinaire, como se percebe, também encontramos o conflito "desejo e interdição", na medida em que a "dame" porta um vestido de cor um tanto quanto provocante, violeta púrpura, passando-nos uma imagem de mulher que desperta desejo. Além de apresentar seus belos braços nus, sem cobri-los como sinal de pudor.Em contrapartida, essa mesma "dame" tem olhos azuis que dançam como anjos, dentes brancos e lábios bastante vermelhos, descrição típica de uma virgem alva.

Nesse sentido, devemos ainda mencionar um fator relevante para a temática da mulher-estátua na estética parnasiana, o seu surgimento como consequiência do positivismo ortodoxo, salientando a função mediadora da esposa e incentivando o culto da santa mãe. Logo, percebemos que tanto Bandeira quanto Apollinaire se utilizam dessa imagem, pois cultuam a mulher como se o fizessem à Virgem.Em função desse aspecto, não podemos deixar de acrescentar a concepção positivista da mulher de June E. Hahnerem, citada por Affonso Romano de Sant' Anna:

Os positivistas ortodoxos rendiam homenagem a Clotilde de Vaux, inspiradora de Augusto Comte, e ao próprio Comte, como fundadores de sua doutrina. Raimundo Teixeira Mendes e Miguel Lmos, líderes do Apostolado Positivista Brasileiro, seguiam as idéias de Pierre Lafitte e deos comteanos ortodoxos quanto aos assuntos sociais e religiosos e quanto à organização da sociedade, destacando enfaticamente a preponderância da família e a importância das liberdades individuais... O pedestal em que a mulher estava colocada foi um dos pilares do positivismo ortodoxo no Brasil. Os positivistas elevaram a mulher por meio do que se poderia ser considerado a transfiguração do culto da Virgem. A feminilidade como um todo devia ser adorada e colocada a salvo de um mundo perverso. Para os positivistas, a mulher era base da família, que por sua vez era pedra fundamental da sociedade. Ela formava o núcleo moral da sociedade, vivendo basicamente por meio dos sentimentos, ao contrário do homem. Dela dependia a regeneração da sociedade. (SANT'ANNA, 1984, p.66 e 67) 
Essa feminilidade adorada e salva de um mundo perverso pode ser ainda exemplificada nos versos de "1909" em que a mulher amada possui tamanha beleza que ninguém ousaria amá-la, ou seja, ela existe apenas para ser contemplada: "Elle était si belle/ Que tu n'aurais pas osé l'aimé"(v.21 e 22). Nota-se, então, nos versos 28 e 29 a confirmação dessa estética da adoração, pois o eu-lírico, fazendo a repetição da mulher que tem atributo de beleza estonteante, diz que isso chega até mesmo a causar-lhe medo. Em outras palavras, essa beleza que lhe provoca paúra a coloca em seu devido lugar, em um pedestal para ser não mais que cultuada, com o temor o temor dos santos e o desejo da carne: "Cette femme était si belle/ Qu'elle me faisait peur".

Em Manuel Bandeira ocorre o mesmo, visto que a mulher amada também apresenta beleza rara, estando acima do sujeito poético, confirmando a sua posição sobre um supedâneo. Assim, o eu-lírico irresoluto ao ver a sua amada, diante de surpreendente beleza, chega a balbuciar e se acovardar, corroborando a concepção da estética parnasiana da mulher-estátua que existe unicamente para ser adorada, causando temor naquele que a cultua como uma santa e alimentando um desejo que cresce de hora em hora.

Portanto, nos versos de "1909" e de "Confissão", a mulher amada é de tamanha superioridade em relação ao amante que, já de antemão, sabemos que a concretização dessa relação é impossível, visto se tratar de um amor puramente contemplativo.

\subsection{Ainda que o júbilo desponte em meio à melancolia}

Prosseguindo com nosso estudo, analisamos o poema "Automne malade", cuja data de composição é incerta (quiçá 1902), e observamos que ele é constituído por imagens ora de vida, ora de morte: 
Automne malade

Automne malade et adoré

Tu mourras quand l'ouragan soufflera dans les roseraies

Quand il aura neigé

Dans les vergers

Pauvre automne

Meurs en blancheur et en richesse

De neige et de fruits mûrs

Au fond du ciel

Des éperviers planent

Sur les nixes nicettes aux cheveux verts et naines

Qui n'ont jamais aimé

Aux lisières lointaines

Les cerfs ont bramé

Et que j'aime ô saison que j'aime tes rumeurs

Les fruits tombant sans qu'on les cueille

Le vent et la forêt qui pleurent

Toutes leurs larmes en automne feuille à feuille

Les feuilles
Qu'on foule
Un train
Qui roule
La vie
S'écoule

Notamos que a vida do eu lírico é embebida da dicotomia presente na estação enferma - "automne malade" -, que representa metaforicamente as angústias e as alegrias do sujeito poético, em um clima penumbrista de influência crepuscular típica da segunda década do século XX. Contudo, esse sujeito poético nos remete ao título da obra que pesquisamos - Alcools -, pois, para amenizar o seu pesar, embriaga-se do fazer poético, único subterfúgio capaz de apaziguar a dor decorrente da passagem do tempo e dos amores.Ao analisarmos um cenário extremamente pesaroso, o vimos concomitantemente de forma esplendorosa, por meio dos óculos da embriaguez poética, confirmando a dualidade existente na estação outonal. Embora haja a presença de imagens antagônicas no campo lexical do poema, de vida (criação poética) e de morte (o fim de todas as coisas), notamos, de acordo com Lecherbonnier (1983, p. 17), que, como toda embriaguez, aquela da criação poética é passageira. A súbita emoção poética 
é uma eterna insatisfação, embebida em seus "alcools" e, como um drogado, não pode se separar dos mesmos sem correr o risco de emergir novamente na desesperança:

Le poète, au terme de sa réflexion, sait que seule la poésie peut lui apporter soulagement et consolation, lui permettre d'oublier la fuite du temps et des amours. Mais comme toute ivresse, celle de la création poétique est passagère. Le fou de poésie est un éternel insatisfait, rêvé à ses alcools, et tel un drogué, il ne peut se séparer d'eux sans risquer de sombrer dans le désespoir.

O contraste dos termos lexicais representa tanto uma estação rica, por sua abundância de frutos representados pela criação poética, quanto a sua fragilidade e instabilidade, devido ao inverno vindouro. Consideramos para isso a oposição das cores e das imagens no campo lexical, demonstrando a opulência do outono, como em “adoré" (v. 1), "vergers" (v. 4), "richesse" (v. 6), "fruits mûrs" (v. 7), "fruits tombant" (v. 15). Quanto aos termos antagônicos, temos o fausto do outono, que se opõe à sua extinção, como nos v. 1 (“malade"/"adoré”), v. 3-4 (“aura neige"/"vergers"), v. 7 ("neige"/"fruits mûrs"), seguindo a cor do ouro dos frutos, que se opõe à brancura invernal da neve. Essa dicotomia lexical trabalha com o valor simbólico do outono, estação representativa da vida em seu ápice, com todos os seus prazeres e alegrias, e o seu término imediato, apresentando toda a sua frivolidade.

Considerando a dicotomia existente no campo lexical, devemos trabalhar com a ambientação na qual ele está inserido, o outono, estação símbolo do tempo que passa, sensível à posição que marca essa época do ano, fecunda por seus frutos mas ameaçada pelo inverno. Ainda podemos dizer que, segundo Morhange-Bégué \& Lartigue, (1993, p. 76-77) essa estação é de suma importância para Apollinaire, dada a relação afetiva que mantém com ela. Essa predileção se deve, segundo os autores, ao seu signo astrológico - virgem -, já que, nascido em 26 de agosto, a data marca aproximadamente o início do outono europeu. Pode-se até mesmo ir além e considerar que se trata de uma "estação mental", em que se exprime "naturalmente" a sensibilidade do poeta. Ou mesmo, que se trata de uma paixão pela natureza outonal, um certo tipo de “determinismo astrológico".

Conforme essa hipótese, a afetividade do poeta com a estação outonal se explicita por meio de sua personificação. A personificação se manifesta no discurso poético 
através da escolha da segunda pessoa do singular, como se o poeta dialogasse com a estação. Em virtude desse jogo, observamos nos versos 5 e 6 uma certa simpatia, com traços de piedade: "Pauvre automne / Meurs en blancheur et en tristesse". Acontece o mesmo nos versos 2 e 14: "Tu mourras" e "tes rumeurs". Enfim, a escolha do adjetivo "malade" do título, retomado no verso 1, colabora com a humanização do outono, cuja fragilidade lembra uma característica humana.

Ao fazermos uma aproximação entre a biografia do autor e a estação, notamos a presença de traços de melancolia em seu poema, pois o autor se intitula como "a própria tristeza": "Je suis la tristesse même, mais non la vilaine et pauvre tristesse qui assombrit tout. La mienne brille comme une étoile, elle illumine le chemin de l'Art à travers l'effroyable nuit de la vie" (APOLLINAIRE, Apud LECHERBONNIER, 1983 , p.86) Em outras palavras, essa tristeza, ao mesmo tempo que lamenta as coisas findas, transforma a dor em canto, dando-lhe vida. Mas devemos tomar cuidado ao realizarmos essa aproximação entre o autor e a sua obra, pois Apollinaire intitulou comemoração e não relação a cada acontecimento de sua vida, o que evita o risco de fazer uma leitura biográfica do poema e da obra em geral: “On aura remarqué qu'il dit 'commémoration' et non 'relation', ce qui écarte la tentation d'une lecture purement biographique, mais autorise à s'interroger sur la relation de tel ou tel poème aux circonstances de la vie de l'auteur." (DÉCAUDIN, 1993, p. 102)

Da mesma forma, encontramos ainda a opulência do outono sendo ameaçada por sua destruição nos versos 2 e 8-11. Pois encontramos essa riqueza outonal sendo intimidada pelo sopro da tempestade, anunciada pelo futuro do verbo (v. 2): "Tu mourras quand...”. Essa dialética no campo lexical prossegue nos versos “Au fond du ciel", "Des éperviers planent", "Sur les nixes nicettes aux cheveux verts et naines", "Qui n'ont jamais aimé". Segundo Morhange-Bégué \& Lartigue (1993, p. 78), os "nixes", sobre os quais voam as aves de rapina são, na mitologia germânica, as Ondines, divindades das águas. Elas lembram, neste contexto, o Rhin (seus cabelos "verdes" seriam algas). Assim, o vocábulo "nicettes" significa no francês antigo "simplettes", sendo que o adjetivo é chamado foneticamente por "nixes" mas ele apresenta ainda um valor depreciativo retomado por "naines". Por fim, essas “ondines" são as mulheres "en mal d'amour", simbolizando o fracasso que existe no ato de amar, ligado na poética apollinairiana aos temas outonais. 
Contudo, notamos que, por meio das figuras mitológicas junto ao outono, o sujeito poético apresenta as conseqüências amargas que existem no ato de amar, demonstrando realmente que a vida é um misto de angústia (morte ou término de todos os sentimentos e situações) e de esperança (os prazeres, os amores e a criação poética). Devido a essa dialética presente na estação, observamos que as "Ondines" representam a figura da mulher como um ser traiçoeiro e atroz, que leva, como as personagens mitológicas, à morte, e que a vida se assemelha ao outono. Estamos presos nesta estação doente, repleta de morte, estando as lembranças guardadas de nossa existência à mercê do fim próximo. A fim de explicitar essa idéia, citamos um trecho da obra de Lecherbonnier (1983, p. 17-18):

la femme est à la fois envoûtante et atroce, le monde ressemble à une prison où l'on tourne tous en rond, la vie ressemble à l'automne, saison malade de la mort, nous passons notre existence à changer d'hôtel, à errer, les souvenirs enfin sentent et annoncent la mort prochaine.

Nessa binomia observada na ambientação, vimos que o outono - estação de prenúncio do trágico - é, ainda, responsável pela separação dos amantes, como metáfora do fim dos sentimentos humanos, e apresenta uma outra profundidade que, não somente como na primavera, com o florescer do amor, e no verão, com o espalhar de sua força. Esta estação é responsável, como uma lição de amor, pela reconciliação do homem consigo mesmo que, por meio da tristeza e do sofrimento, eleva-se e se ilumina, extraindo desses sentimentos a aura profunda de sua natureza. Por certo, essas imagens outonais de separação e de morte nos remetem ao caráter dialético que essa estação representa, a esperança e a desesperança, isto é, o fim de todas as coisas, a morte (desesperança), e a condição de um eterno retorno (esperança), recuperação do perdido, embora ilusoriamente. Desse modo, esse jogo irônico nos revela toda uma atmosfera antagônica e notadamente pessimista que, embora vivamos constantemente na esperança de reencontrar o tempo de júbilo localizado no passado, temos a certeza da impossibilidade do seu retorno.

Ademais, não podemos nos esquecer de que esse poema é extremamente musical, pois o poeta incita a imaginação sonora do leitor por meio da natureza, com todos os "sons" outonais que apresenta: le souffle de l'ouragan (v. 2), les brames des cerfs (v. 
13), la plainte du vent (v. 16). Além, é claro, da "transcrição" musical dos "barulhos" no registro poético, através das vogais no verso 2 , de quinze sílabas, no qual observamos a repetição por três vezes da seqüência sonora ou / ra / na: “Tu mourras quand l'ouragan soufflera dans les roserais".

Observamos aqui que os sons da natureza, juntamente com a imagem apresentada, sugerem um certo lamento outonal, na primeira parte do poema, destacando o sopro dessa crescente estação gélida. Já nos seis últimos versos de duas sílabas, notamos a inexorabilidade do tempo, o ritmo decrescente da vida que se esvai, "la vie qui s'écoule". Com esse recurso sonoro, o poeta trabalha com o fenômeno do eco, "foule" / "roule" / "s'écoule", marcando o distanciamento progressivo do "train qui roule", e da passagem do tempo. Por fim, as imagens das folhas mortas também acentuam essa idéia de que tudo há de passar, como disse Santo Agostinho. Assim, podemos afirmar que o poeta trabalha com destreza a junção que faz entre as imagens, o tema e a sonoridade poética.

É, portanto, essa dialética explicitada por meio do campo lexical na ambientação outonal que mostra toda a problemática existente no ato de viver, com todas as suas agruras e os seus deleites, sendo as primeiras predominantes na vida da figura do malaimé, corroborando a idéia de que ainda que o júbilo desponte em meio a melancolia, esse viverá sempre à mercê de seu infortúnio.

\section{Crepúsculo de Outono}

(Cladavel, 1913)

O crepúsculo cai, manso como uma benção. Dir-se-á que o rio chora a prisão de seu leito... As grandes mãos da sombra evangélicas pensam As feridas que a vida abriu em cada peito.

O outono amarelece e despoja os lariços.

Um corvo passa e grasna, e deixa espaço no ar $\mathrm{O}$ terror augural de encantos e feitiços.

As flores morrem. Toda a relva entra a murchar.

Os pinheiros porém viçam, e serão breve Todo o verde que a vista espairecendo vejas, Mais negros sobre a alvura inânime da neve, Altos e espirituais como flechas de igrejas. 
Um sino plange. A sua voz ritma o murmúrio

Do rio, e isso parece a voz da solidão.

E essa voz enche o vale... o horizonte purpúreo...

Consoladora como um divino perdão.

$\mathrm{O}$ sol fundiu a neve. A folhagem vermelha

Reponta. Apenas há, nos barrancos retortos,

Flocos, que a luz do poente extática semelha

A um rebanho infeliz de cordeirinhos mortos .

A sombra casa os sons numa grave harmonia.

E tamanha esperança e uma tão grande paz

Avultam do clarão que cinge a serrania,

Como se houvesse aurora e o mar cantando atrás.

(BANDEIRA, 1982, p. 11)

Observamos que a criação poética elegíaca vista em "Crepúsculo de Outono" denuncia uma influência crepuscular típica da segunda década do século XX, permeada pelo penumbrismo da literatura da época. Assim, nesse clima exacerbadamente nostálgico de influência crepuscular, notamos que o contraste dos termos lexicais sugere a fragilidade, a instabilidade e a riqueza do outono (estação que representa metaforicamente os sentimentos humanos), manifestando-se na oposição das cores e das imagens. Os termos antagônicos podem indicar tanto a vida do sujeito poético, representado por essa estação instável, quanto a sua morte vindoura: "negros/alvura" (v. 11); "sol/neve" (v. 17); "flores/morrem" (v. 8). E ainda, o esplendor do outono é apontado através dos termos lexicais “viçam e breve" (v. 9), seguidos por “esperança” e "paz”. Portanto, o valor simbólico do outono, por meio de um jogo sutil de contrastes, anuncia paralelamente tanto a vida fértil quanto a chegada imediata do fim. Por isso, ao estudarmos essa linguagem antagônica, por meio da estação "outono", lembramos que a crítica menciona constantemente que muitos poemas de A cinza das horas foram inspirados na natureza. Dessa forma, Bandeira trabalha com correspondências entre o comportamento da natureza e a alma dos homens, demonstrando toda a nostalgia da existência humana.

Essa luta de contrastes, em um cosmo que denuncia a melancolia no ato de viver dos primeiros poemas líricos de Bandeira, apresenta o amor com suas notas de angustiante confiança, o que nos leva de volta às tensões petrarquistas entre gelo e fogo, entre esperança e desespero (Cf. PONTIERO, 1932, p. 46). Essas tensões caracterizam 
um eu-lírico que vivencia um conflito existencial, quando a vida em sua máxima intensidade se doa em morte. Como o amor que a figura do mal-amado vivencia em seu ápice em um passado indeterminado e que logo em seguida presencia a tristeza de sua rápida passagem.

Nessa poética de contrastes ou nessa criação da poesia por meio da visão alumbrada, Bandeira trabalha com a contradição e a contaminação dos opostos que, em sua complexidade, aparece resguardada na ambigüidade do branco, ao mesmo tempo material e imaterial, concreto e abstrato, aparência sensível e iluminação espiritual (Cf. ARRIGUCCI, 1990, p. 161). Desse modo, essas tensões que aparecem no poema nos remetem ao próprio poeta Manuel Bandeira, que viveu de maneira acentuada a morte, que o acompanha em toda a sua trajetória, consigo e com aqueles que amou e que partiram abruptamente.

Logo, Bandeira passa para a sua poesia o viver intensamente e o morrer inevitável, aquilo que presenciou em toda a sua existência. Portanto,

aquela umidade febril da tísica se infiltrou por tudo e embolorou tudo. Um veludo silencioso amaciou a rigidez, a linha aguda, a reta cruel da vida. A tuberculose para Manuel Bandeira é que nem a campainha incessante sonora de certos cinemas de sessões corridas (LOPEZ, 1987, p. 73).

No campo lexical, composto por termos opostos, consideramos a ambientação na qual ele está inserido, o outono, estação símbolo do tempo que passa, sensível à posição que marca essa época do ano, fecunda pelos seus frutos, mas ameaçada pelo inverno. (Cf. MORHANGE-BÉGUÉ \& LARTIGUE, 1993, p. 76). Por isso, observamos que essa estação é de suma importância para o poeta, como se ele estabelecesse com ela uma relação afetiva, pois em Clavadel, Suíça, quando vai se tratar da tuberculose, passa quinze meses decisivos, de julho de 1913 a outubro de 1914, quando "aprende a não morrer" (HOLANDA \& BARBOSA, 1958, p. LXIX). Nesse período Bandeira vive uma estação representativa da vida pelos seus frutos e da morte pelo seu inverno ameaçador. Essa estada devolve ao jovem a revitalização que, desde os dezoito anos, havia perdido. Por isso, a relação afetiva do autor com a estação pode representar ou servir como um espelho de seu estado emocional em Clavadel, ora com apetite divino de vida e de amar, ora no inverno gélido da morte. 
O poema "Crepúsculo de Outono" é construído por meio de imagens opostas, representando ora a esperança de viver ora o desespero de estar nesse mundo ermo de angústia e solidão. O próprio rio presente no poema representa a melancolia do eupoético, pois esse chora a prisão de seu leito, o lamento de sua infeliz condição humana, por meio de uma melodia bastante característica da figura do mal-amado, o choro: "Dirse-á que o rio chora a prisão de seu leito..." (v. 2). Essa melodia elegíaca que o rio apresenta traz nostalgia e se torna uma companheira inseparável e suave para a própria cantiga de solidão, mas, ao mesmo tempo, o eu-lírico pode encontrar uma beleza estranha e um consolo na atmosfera cinzenta de um "corvo que passa e grasna", no "terror augural de encantos e feitiços".

Para aqueles que estão solitários, a melodia do rio traz consolo, vide versos 13 a 16: "O sino plange. A sua voz ritma o murmúrio/Do rio, e isso parece a voz da solidão./E essa voz enche o vale... o horizonte purpúreo.../Consoladora como um divino perdão.”. Observamos que o estado de espírito desse sujeito-poético pode ser tão teimoso quanto o conturbado espírito do próprio poeta, mas a água indicada (essencial à vida) ou a sua melodia no rio pode nutrir a sua alma da mesma forma que nutre o solo. Logo, esse fascínio pela água, personificada em todas as suas manifestações, remete-nos à associação direta que o eu-poético faz entre seu próprio sentimento e a voz inconsolável do mar, vide versos 21 a 24: "A sombra casa os sons numa grave harmonia./E tamanha esperança e uma tão grande paz/Avulta do clarão que cinge a serrania,/Como se houvesse aurora e o mar cantando atrás."

O poeta de A cinza das horas é inegavelmente um poeta triste que não compreende bem a razão de ser da vida e faz versos "como quem chora, de desalento... de desencanto". É o melancólico que ama a solidão e as confissões e se acaso chega a ouvir a voz da alegria é sempre como uma "voz de fora" que vem até ele mas que não o consegue empolgar e dominar por muito tempo" (Cf. LOPEZ, 1987, p. 90). Mas, ao lado do grande pesar na vida do eu-lírico banderiano, notamos que o outono se apresenta como uma estação abençoada, visto que o vocábulo crepúsculo indica: luminosidade proveniente da iluminação das camadas superiores da atmosfera pelo sol, quando embora escondido, está próximo do horizonte (Cf. FERREIRA, 1993, p. 153). Assim, o crepúsculo de outono vem para aquecer, perenizar e revitalizar essa estação tão ameaçadora, que petrifica com seu inverno devastador os sentimentos humanos. Dessa forma, nos versos -“O crepúsculo cai, manso como uma benção./Os pinheiros 
porém viçam, e serão breve/Todo o verde que a vista espairecendo vejas,/Mais negros sobre a alvura inânime de neve,/Altos e espirituais como flechas de igrejas./O sol fundiu a neve. A folhagem vermelha/Reponta.” (v. 1, 9-12, 17-18),- notamos que o sol do crepúsculo funde a neve que é inânime para trazer vida à natureza, à folhagem vermelha que agora reponta, aos pinheiros que viçam, rompendo com aquela condição de paralisia mortífera que o outono apresenta por meio do seu inverno gélido.

Embora haja essa dicotomia lexical (morte/vida - angústia/esperança), o poema "Crepúsculo de Outono" evoca um comportamento de tranqüilidade e contemplação espiritual, havendo muito que admirar no retrato vivo do ritual de outono, com seus encantos e magias misteriosos, transformando as cores e os contornos da paisagem e mergulhando o mundo em estado de inefável paz. (Cf. PONTIERO, 1986, p. 42), mas que ao mesmo tempo simula a dor do sujeito poético mal-amado que sabe que tal mansidão não o livra de sua condição primeira, de eternamente desdichado.

Logo, o poema "Crepúsculo de Outono" é característico do lirismo elegíaco da poesia banderiana. Nele, encontramos temas de seu universo poético, como o outono frágil, o tempo que corre, e ainda a passagem da vida para a morte, visto que esta estação é um divisor de águas entre a fertilidade da vida, por seus frutos, e a efêmera existência dos sentimentos humanos como metáfora do inverno devastador, sendo esse último tão voraz que elimina qualquer resquício de júbilo na vida do eu-lírico mal-amado.

\section{Bandeira e Apollinaire}

Dando continuidade à proposta comparatista calcada na crítica temática do tempo não-reconciliado, trabalhamos com os poemas "Automne Malade" e "Crepúsculo de Outono", que são constituídos por imagens ora de vida ora de morte.

Considerando tal subtema, observamos que em ambos os poemas a criação poética elegíaca denuncia uma influência crespuscular típica da segunda década do século XIX, permeada pelo penumbrismo da literatura da época. Apresentando influência ainda de algumas características simbolistas, o [s] poeta [s] crepuscular se instalam em uma parte do mundo e contam as suas tristezas (ROSENBAUM, 1993, p. 28)

Nesse clima exacerbadamente nostálgico de influência crepuscular, notamos em "Crepúsculo de Outono" que o contraste dos termos lexicais sugere a fragilidade, a instabilidade e a riqueza do outono (estação que representa metaforicamente os sentimentos humanos), manifestando-se na oposição das cores e das imagens. Nesse 
viés, os termos antagônicos podem indicar tanto a vida do sujeito poético, representado por essa estação instável, quanto a sua morte vindoura. Portanto, o valor simbólico do outuno, por meio de um jogo sutil de contrastes, anuncia paralelamente tanto a vida fértil quanto a chegada imediata do fim. Assim, essas tensões caracterizam um eu-lírico que vivencia um conflito existencial, quando a vida em sua máxima intensidade se doa em morte. Em face disso, remetemo-nos ao tema de nosso projeto, pois nesse a figura do mal-amado vivencia o amor em seu ápice, em um passado indeterminado e logo em seguida a tristeza de sua rápida passagem.

A dicotomia lexical é também observada em "Automne Malade", pois o contraste dos termos lexicais, do mesmo modo que em "Crespúsculo de Outono", representa tanto uma estação profícua pela abundância de frutos, representados por meio da criação poética, quanto a sua fragilidade e instabilidade devido ao inverno que a acompanha.

No campo lexical composto por termos opostos, consideramos ainda a ambientação na qual ele está inserido, o outono, estação símbolo do tempo que passa, sensível à posição que marca essa época do ano, fecunda pelos seus frutos, mas ameaçada pelo seu inverno (MORHANGE-BÉGUÉ \& LARTIGUE, 1993, p.). Por isso, observamos que essa estação é de suma importância para o poeta, como se ele estabelecesse com ela uma relação afetiva, pois em 1913 a outubro de 1914, ele “aprende a não morrer" (HOLANDA \& BARBOSA, 1958, p. LXIX). Nesse período Bandeira vive uma estação representativa da vida pelos seus frutos e da morte pelo seu inverno ameaçador. Essa estada devolve ao moço a revitalização que desde os dezoitos anos havia perdido.

É, pois, o que ocorre de forma semelhante em Apollinaire, pois temos também a ambientação outonal, estação símbolo, como já foi mencionado, do tempo que passa ininterruptamente, fecunda pela abundância de frutos mas ameaçada pelo inverno vindouro. Semelhantemente a Bandeira, a estação "outuno" é de suma importância para Apollinaire, como se também esse mantivesse uma relação afetiva com ela.

Devemos mencionar que "Le Pont Mirabeau" e "Automne Malade" são poemas musicados: tanto em um quanto no outro encontramos sons e vozes outonais que nos remetem a uma melodia de fundo, sendo essa notadamente melancólica. Esse aspecto pode ser percebido na melodia do próprio rio presente no poema "Crepúsculo de Outono", canção do eu-poético que chora a prisão de seu leito, o lamento de sua infeliz condição humana, por meio de uma música característica da figura do mal-amado, o 
choro: "Dir-se-á que o rio chora a prisão de seu leito..."(v.2). Essa melodia elegíaca que o rio apresenta traz nostalgia e se torna uma companheira inseparável e suave para a própria cantiga de solidão mas, ao mesmo tempo, o eu-lírico pode encontrar uma beleza fúnebre; trata-se de um consolo na atmosfera cinzenta de um "corvo que passa e grasna", "no terror algural e encantos e feitiços"..., alimentando a sua condição primeira de mal-amado, que senão como tal, não tem razão de existir. Desse modo, até mesmo a musicalidade no poema é representada pela binomia, visto que essa tanto alimenta a melancolia no sujeito poético quanto o consolo. Por isso, o fascínio pela água, personificada em todas as suas manifestações, remete-nos à associação direta que o sujeito poético faz entre seu próprio sentimento e a voz inconsolável do mar. Logo, se as vozes da natureza (as notas musicais) e seus elementos lembram o mau destino da figura do mal-amado (o fim de todas as coisas), sua solidão e seu desepero também lhe aconselham paciência e submissão (PONTIERO, 1932, p. 45-46)

O mesmo traço de musicalidade é encontrado em "Automne Malade"; no entanto, de forma diferenciada quanto à binomia lexical, pois aqui o poeta também incita a imaginação sonora do leitor por meio ainda da natureza, mas sem demonstrar explicitamente a dialética existente nesse recurso, com todos os seus "sons" outonais: "le souffle de l'ouragan" (v. 2), "le brame de cerfs" (v. 13), "la plainte du vent" (v. 16). Além da transcrição musical dos "barulhos" no registro poético, através das vogais no verso 2 , de quinze sílabas, no qual observamos a repetição por três vezes da sequiência sonora: ou / ra / an: "Tu mourras quand l'ouragan soufflera dans les roseraies". Nesse observamos que a sucessão dos sons da natureza com a imagem apresentada, como em Bandeira (a música elegíaca), sugerem um certo lamento outonal, na primeira parte do poema, destacando o sopro dessa crescente estação gélida. Já nos seis últimos versos de duas sílabas, notamos que, de forma semelhante a "Crepúsculo de Outono", a inexorabilidade do tempo, o ritmo crescente da vida que se esvai, ou melhor, trabalhando com a nossa temática do "mal-aimé", que viu o seu grande amor findar com a passagem do tempo: "la vie qui s'écoule". Com esse recurso sonoro, vimos que o poeta trabalha com o fenômeno do eco, "foule"/ "roule" / "S'écoule" marcando o distanciamento progressivo do "train qui roule", e da passagem do tempo. Por fim, a imagem das folhas mortas também sublinha a idéia de que tudo há de passar, como disse Santo Agostinho. 
Vale notar ainda que tal estação representa o falso amor visto que, após a primavera, o verão deveria começar, mas é o outono que se anuncia, contra toda regra da natureza, no ciclo dos amores de Alcools. Desse modo, o "mal-aimé" de fato ignora a estação (verão) da maturidade, da opulência, da claridade, que poderia satisfazer plenamente seus desejos, destruindo a condição que o alimenta, o "mal de amar". Logo, o "falso amor", em ambos os poemas e no ciclo de Alcools, não é um simples acidente da existência, pois é essa última que por si própria soa falso, devido às suas promessas enganadoras.

Portanto, a dialética lexical explicitada na ambientação outono demonstra-nos toda a problemática existente do ato de viver (amar), com todas as suas agruras e seus deleites, prevalecendo as primeiras, posto que ainda que a alegria tente se fazer presente na figura do mal-amado esse viverá eternamente a condição de um tempo não-reconciliado.

\section{7 - 0 destino talhado pele má sina}

Para análise dessa tópica, consideramos o eu-lírico submetido à força do "mau destino" nos poemas "Signe" e "Oceano", cuja melancolia representa toda a sorte de pesares que lhe subjaz.

Nessa perspectiva, iniciamos com "Signe", que primeiramente foi publicado em 1912 com o título "Stances", em seguida retomado e intitulado "Signe de l'automne", para finalmente ser reduzido a uma única palavra "Signe", que reflete melhor que os outros o seu caráter eminentemente simbólico.

\section{Signe}

Je suis soumis au Chef du Signe de l'Automne Partant j'aime les fruits je déteste les fleurs Je regrette chacun des baisers que je donne Tel un nouer gaulé dit au vent ses douleurs

Mon Automne éternelle ô ma saison mentale Les mains des amants d'antan jonchent ton sol Une épouse me suit c'est mon ombre fatale Les colombes ce soir prennent leur dernier vol 
$\mathrm{Na}$ primeira estrofe o sujeito poético se apresenta como alguém submetido ao chefe do signo do outono, ou seja, guiado pelo signo da estação que por si só representa o anúncio do inverno e conseqüentemente da morte de todo resquício de vida: "Je suis soumis au "Chef du Signe de L'Automne" (V.1). Desse modo, devemos mencionar que o outono é um dos temas mais caros a Apollinaire, aparecendo em vários outros poemas de Alcools, simbolizando ora o decurso do tempo e o amor findo, ora o fim de todas as coisas - a morte. Aqui, o que observamos é um eu-poético submerso em uma vida de lamento, marcada pela invocação de um signo (a má sina) que nos faz lembrar da "soumission de Verlaine à Saturne: Or ceux-là qui sont nés sous le signe de Saturne... ont entre tous... Bonne part de malheurs" (LECHERBONNIER, 1983, p. 78). Essa submissão é observada com o outono que traz consigo o declínio da maturidade e a aproximação da morte. Por isso, o eu-lírico diz detestar as flores e amar os frutos, os quais são característicos dessa estação que o constitue como mal-amado: "Partant j'aime les fruits je deteste les fleurs" (V.2).

Essa má sina é confirmada no verso subseqüente, pois os beijos que o eu-lírico dá parecem representar o seu pesar, posto que seu destino é ser mal-amado sob o "signe de l'automne": "Je regrette chacun des baisers que je donne" (V.3). Sendo assim, vimos outra imagem que complementa tal cenário, a comparação que o eu-lírico faz de si com uma árvore tombada que lamenta suas dores ao vento: "Tel um noyer gaulé dit au vent ses douleurs" (V.4).

Nesse viés, temos a certeza de que o sujeito poético é regido pelo signo do outono, quando afirma que esse é a sua eterna estação mental, ou seja, apresenta-se como um "gauche" frente ao seu destino nefasto: "Mon éternelle ô ma saison mentale" (V. 5). Essa ambientação de pesar é nutrida ainda pela imagem das mãos dos amantes de outrora que recobrem o solo de tal estação, como suas folhas secas, simbolizando que tudo jaz, até mesmo o amor dos enamorados: "Les mains des amants d'antan jonchent ton sol" (V.6).

Observamos que o signo do outono tem uma conotação ainda mais funesta, pois quem segue o eu-lírico constantemente é uma sombra fatal, uma esposa extremamente macabra, a morte: "Une épouse me suit c'est mon ombre fatale" (V. 7). Logo, notamos que o eu-poético de "Signe" está predestinado a ter uma vida marcada pelo lamento e 
pela morte, o que é percebido em outros poemas da obra aqui estudada, e reafirma o caráter pesaroso da figura do mal-amado:

la mort est partout dans Alcools. Aux exemples déjà cités on peut ajouter ce "mort qu' on emporte" de "La Dame", la mort du sacristain dans "Les Femmes", celle de la Loreley, et aussi les "nageurs morts" de "La Chanson du mal-aimé", les regards morts du "Voyageur", les heures d' "À la Santé" qui passent "comme passe un enterrement”...(DÉCAUDIN,1993, p.88)

Essa sombra malévola que persegue o eu-lírico é observada na imagem do último verso: "Les colombes ce soir prennent leur dernier vol". Aqui, temos a confirmação de que há um processo infinito de morte nesse cenário, pois até mesmo as pombas dão o seu derradeiro vôo, símbolo da vida de aflição e fatalidade que caracteriza o eu-lírico de "Signe". Assim, toda essa atmosfera pesarosa, tanatológica e austera resultante da má sina do sujeito poético, o signo de outono, apresenta um toque romântico e baudelairiano, na medida em que a consciência da morte cria um estado de melancolia ativa, o spleen necessário à criação.

Prosseguindo com a temática do destino talhado pela má sina, citamos o poema "Oceano".

\section{Oceano}

Olho a praia. A treva é densa.

Ulula o mar, que não vejo, Naquela voz sem consolo,

Qua há na voz do meu desejo.

E nesse tom sem consolo

Ouço a voz do meu destino:

Má sina que desconheço,

Vem vindo desde menino,

Cresce quanto em anos cresço.

- Voz de oceano que não vejo

Da praia do meu desejo ... 
Partindo para a análise do poema "Oceano", observamos um sujeito poético embebido por uma névoa de melancolia, em que olha a praia e se vê afastado da visão pela treva densa: "Olho a praia. A treva é densa.", "Ulula o mar, que não vejo," (V.1 e 2). Assim, nos versos subseqüentes a voz que é percebida é carregada de pesar, como se estivéssemos escutando a lamúria do eu-lírico mal-amado que, na tristeza imensa, apresenta também a voz do seu desejo.: "Naquela voz sem consolo,", "Naquela tristeza imensa", "Qua há na voz do meu desejo." (V. 3 a 5).

Nessa perspectiva, na estrofe seguinte perdura o sentimento melancólico, pois é no tom sem consolo que o sujeito poético escuta a voz de seu destino: "E nesse tom sem consolo", “Ouço a voz do meu destino:" (V. 6 e 7). Logo, o eu-lírico, diante de tal atmosfera de lamento, mostra a má sina que o acompanha desde menino, ou seja, a marca de desafortunado que carrega e que cresce com o passar do tempo: "Má sina que desconheço,", "Vem vindo desde eu menino,", "Cresce quanto em anos cresço.” (V.8 e 10). “Essa vida marcada por um 'mau destino' pode ter uma certa relação com o 'desdichado' de Nerval, pois tanto um quanto o outro caminham sob 'o Sol Negro da Melancolia'. Torna-se de chofre a vida que se anunciava luminosa, e o poeta, de 'bem nascido' que era, transforma-se num deserdado da sorte, a caminhar sob ‘o Sol Negro da Melancolia' como o desdichado de Nerval” (COELHO apud ROSENBAUM, 1993, p.38).

É importante salientar que toda essa vida de predestinação pelo "mau gênio da vida" é observada já no poema que abre A Cinza das Horas, como um atestado da condição desditosa que cerca o poeta e sua obra, o que tomamos aqui como o eu-poético atacado furiosamente pelo "mau destino" em todos poemas analisados, traduzido pelo pesar de um auto-retrato mordaz. Assim, "Desencanto" esclarece esse viés melancólico do livro e do poeta Manuel Bandeira, que adverte os seus leitores que faz versos como quem chora:

Eu faço versos como quem chora

De desalento... de desencanto...

Fecha o meu livro, se por agora

Não tens motivo nenhum de pranto 
Sendo assim, o eu-lírico, que se apresenta como alguém condenado ao infortúnio, retoma, por meio do último dístico, as imagens da primeira estrofe: “- Voz de oceano que não vejo", "Da praia do meu desejo..." (V. 11 e 12), como se estivesse afirmando que a falta de visão seria a ausência de perspectiva ou de alegria em sua vida "madrasta", representada pela "praia deserta de seu desejo". Nesse sentido, considerando a análise, observamos que a essência da voz é modificada ao longo do poema: de voz "de meu desejo" (primeira estrofe) para "voz do meu destino" (segunda estrofe) e desta para "voz de oceano" (terceira estrofe). Há uma certa consonância entre os vocábulos desejo/destino/oceano, passando-nos a mesma idéia de lamento, emitindo o mesmo som de lamúria, a voz sufocada de um eu lírico desditado. Diante disso, na última estrofe, notamos a existência de um travessão, que rompe com o silêncio angustiante: há finalmente a idéia de uma fala. Desse modo, o poema emite a voz que denuncia o pesar sem consolo do eu lírico mal-amado.

Por fim, considerando toda a atmosfera melancólica do poema, vimos que Bandeira, no século XX, revive traços de teor romântico, visto que, com o seu mal pertinaz, a tísica (como o mal du siècle), aborda o caráter triste de se fazer poesia, característica que no Romantismo era sinal de sensibilidade e refinamento.

\section{Apollinaire e Bandeira}

Considerando o diálogo entre Apollinaire e Bandeira no que concerne à temática do destino talhado pela má sina, vimos que o eu lírico de "Signe" e de "Oceano" fundamenta todo o caráter melancólico observado nos outros poemas de Alcools e de $A$ Cinza das Horas, aqui analisados. É por isso que decidimos deixá-los por último, pois após todo o estudo dos subtemas que constroem o sujeito poético mal-amado que vive a dor da ausência e a eterna busca pelo que findou, chegamos à derradeira tópica que realmente corrobora a sua constituição como um ser talhado pelo "mau destino", e que justifica toda a atmosfera pesarosa até aqui examinada.

Desse modo, antes de iniciarmos com a análise temática, destacamos alguns aspectos formais que constituem o processo de versificação nos poemas. Em "Signe" temos dois quartetos, rimas alternadas abab, cdcd, alexandrinos e no total 8 versos.Vimos também que a alternância tradicional de acordo com as regras clássicas das rimas (rimas femininas e rimas masculinas) é aqui abolida, pois segundo Vaillant (1992, p.58), Apollinaire utiliza uma alternância entre rimas vocálicas “(dont le dernier son perçu est 
une voyelle: ton/prison) et rimes consonantiques (dont le dernier son perçu est une consonne: port/dore)". É o que acontece em "Signe", pois ora temos o som vocálico "automne", ora o som consoântico "fleurs", alternadamente, até o final do poema.

Já "Oceano" apresenta três estrofes, duas quintilhas e um dístico, rimas em abcab, cdede, bb, heptassílabos e, no total, 12 versos. Observamos alguns efeitos sonoros decorrentes dos jogos vocálicos do poema, como as aliterações em [v] "vem vindo" relacionadas às assonâncias das vogais [e] e [i], que se alternam "vem,vindo,menino" e a sua nasalidade (vem, vindo, menino). Assim, é importante destacar a vocalização fechada do poema em "e, i, o, além da maioria das rimas no final dos versos, exceto duas, com vogais abertas "densa e imensa", terminarem com o som vocálico fechado “o”, dando-nos a impressão do crescimento sombrio e assustador da má sina.

Dando seqüência à temática do "mau gênio da vida", observamos tanto em Signe" quanto em "Oceano", um cenário que transborda melancolia, como se tivesse a função de alimentar ou completar a condição de existência do sujeito poético que por si só já é pesarosa. Assim, o eu-lírico apollinairiano diz ser submetido ao nefasto "Chef du Signe de l'Automne", como uma má sorte, e aprecia tudo aquilo que o representa, os frutos e não as flores. Ainda nessa ambientação mordaz, o sujeito poético nega qualquer resquício de alegria, pois lamenta até mesmo os beijos que dá, comparando-se a um "noyer gaulé", uma árvore derrubada que conta suas dores ao vento: "Je suis soumis au Chef du Signe de l'Automne", "Partant j'aime les fruits je detéste les fleurs", "Je regrette chacun des baisers que je donne", "Tel um noyer gaulé dit au vent ses douleurs" (V.1 a 4).

O mesmo ocorre em "Oceano", pois o eu-lírico também está inserido em uma atmosfera soturna, cuja treva densa lhe esconde qualquer sentimento de alegria. Esse não vê o mar e confirma a falta de visão diante da crença de uma vida de gozo, ou seja, o que assiste é apenas a tristeza imensa e sem consolo da voz do seu desejo: "Olho a praia. A treva é densa.", "Ulula o mar, que não vejo,", "Naquela voz sem consolo,", "Naquela tristeza imensa", "Qua há na voz do meu desejo." (V. 1 a 5).

Logo, o profundo pesar do eu-lírico nos dois poemas é justificado na segunda estrofe, pois tanto um quanto o outro indicam que o "mau destino" os acompanha, de maneira que em Apollinaire isso é traduzido pelo tema do outono, como um signo de mau agouro que rege o sujeito poético, sendo a sua estação mental: "Mon Automne éternelle ô ma saison mentale" (V. 5). Além de outra imagem que sustenta essa condição de condenado do eu-poético, as mãos dos amantes de outrora que recobrem o 
solo dessa estação mental, dando-nos a impressão de que tudo está predestinado à tristeza e à morte. Como ele, que é perseguido por uma esposa funesta,sua sombra fatal, ou a morte: "Les mains des amants d'antan jochent ton sol”, "Une épouse me suit c'est mon ombre fatale" (V. 6 e 7).

Em Bandeira, isso é visto do mesmo modo, pois no tom sem consolo o eu-lírico diz ouvir a voz do seu destino que, como em Apollinaire, é representado por uma má sina que o persegue desde menino e cresce de tempos em tempos. Logo, notamos que o sujeito poético também se apresenta como ser maldito, cuja condenação ao infortúnio é a sua condição de existência: "E nesse tom sem consolo", "Ouço a voz do meu destino:", "Má sina que desconheço", "Vem vindo desde eu menino,", "Cresce quanto em anos cresço." (V. 6 a 10).

Nessa perspectiva, é importante mencionar o papel de Bandeira e Apollinaire, pois fazendo parte do Modernismo, apresentam traços notadamente parnasianosimbolistas e românticos em suas primeiras obras, e colocam-se como os poetas "malditos", cantores do mal, de acordo com a poesia do mal proposta por Baudelaire. Todo o tédio baudelairiano é observado em Apollinaire e Bandeira, visto que esses passam a incorporar a condição de malditos, e demonstram indiretamente, por meio de seus poemas elegíacos, que a arte de fazer poesia não é valorizada pela burguesia, posto que não tem o teor utilitarista que essa classe procura em tudo.

Essa má sina observada nos dois poetas como prenúncio de maldição, notada já na poesia decadente, demonstra a condição moderna do poeta e da poesia na civilização industrial, que são postos na marginalidade pela burguesia, o que será visto também em Drummond como o anjo torto que condena o poeta a ser gauche na vida.

Além da leitura do poeta moderno frente à civilização industrial, Bandeira apresenta também um outro fator de cunho romântico que o faz diferente do modelo de homem viril imposto pela sociedade: ele é acometido pela tísica, transformando, de acordo com Susan Sontag, a doença num meio de diferenciação social, sobretudo do artista frente aos outros. Nesse viés, o artista/Bandeira é visto como um ser diferenciado nessa civilização que objetiva a competição e a produtividade. Então, o poeta doente assume a condição maldita e marginal na sociedade, sendo a sua melancolia representativa dos artistas sensíveis e refinados, posto que o sentimento da tristeza tinha essa conotação no Romantismo: 
o mito da tuberculose constitui o episódio quase derradeiro na longa carreira da antiga melancolia - que era a doença do artista, de acordo com a teori dos quatro humores. O caráter do melancólico - ou tuberculoso - era um caráter superior, sensível, criativo, um ser à parte. (MARTINS apud SONTAG, 1994, p. 80)

Essa tristeza está intimamente ligada ao lirismo de Bandeira, pois dos seus 344 poemas, nada menos que 115 apresentam vocábulos pertencentes a esse campo semântico. Assim, todo o pesar dessa poesia, além de ser representado por cenários sombrios e crepusculares de teor simbolista-decadentista, também exibe uma gama de palavras das quais destacamos apenas algumas, retiradas dos 11 poemas aqui estudados: “pesar”, “pranto”, “desesperança”, “dolorosas”, “magoa”, “solitário”, “tortura”, “mal”, "chora", “desfalece", “melancolia", “sombria”, “ais", “amargo", “incontentado", "morreu", "súplice", "soluçar", "penar", "distância", que explicitam a atmosfera melancólica do artista/Bandeira, caracterizado como um homem fadado à morte.

Ademais, Apollinaire também se coloca como um poeta marcado pelo "mau destino" (signe de l'automne), quando em seus poemas questiona a sua misteriosa origem, o seu pai enigmático e a vida noturna de sua mãe ("Le Larron”), a sua caracterização como mal-amado com seus amores frustrados ("Marie"), a sua prisão em Santé ("À la Santé"), suas intempéries de ordem financeira, ("La Porte"), e ainda por meio de uma reflexão que faz em um caderno de notas de 1899 (publicado por Lawler dans le Mercure de France de primeiro de janeiro de 1955 que revela ou justifica de forma relevante sua melancolia e sua condição de poeta:

a ... pensait somnolent, sur son lit dans l'obscurité douce de la chambre qui succède aux repas de midi. "Pourquoi ne suis-je pas né riche comme tant d'autres. Pourquoi mon avenir se presente-t-il mystérieux, hermétique alors que les autres, riches, ne voient dans l'avenir qu'une succession de fêtes, de noces, avec le gâtisme fatal à l'heure du mariage, tandis que moi...J'eus mieux fait au lycée de bûcher mes maths et d'essayer Centrale, de tâcher d'en sortir ingénieur, d'avoir une position assurée. Non, au lieu de travailler, j'ai fait des vers, j'ai eu des rêves, je me suis occupé de Littérature, merde, merde". Ces derniers mots furent prononcé à mi voix. Et là-dessus la pendule sonnant deux heures il se leva. Allumant une cigarette il songeait encore. Sa mère.... (DÉCAUDIN,1993,p.103) 
Essas alusões autobiográficas na poesia de Apollinaire, são comemorações como ele mesmo escreveu a Henri Martineau, "Chacun de mes poèmes est la commémoration d'un événement de ma vie". Mas ao mesmo tempo, é importante salientar que ele diz "comemoração" e não "relação", o que nos protege de qualquer leitura puramente biográfica, embora garanta a possibilidade de "comemorar" tais circunstâncias da vida do poeta por meio de seus poemas.

Toda a carga melancólica de sua poesia, como em Bandeira, pode ser vista no léxico utilizado em sua obra, aqui no caso, Alcools, além de cenários também sombrios e crepusculares típicos da poesia de cunho simbolista-decadentista. Assim, ligado ao campo semântico da tristeza, relacionamos alguns vocábulos que aí se inserem, dos outros 11 poemas analisados nessa pesquisa: "regrette", "douleurs", "ombre", "malade", “automne”, "pleurent”, "larmes", "lamenter", "peine”, “mal”, “crépuscule”, "morts”, "s'éxtenue", "mal aimé", que, do mesmo modo que Bandeira, demonstram a via triste de se fazer poesia e a condição predestinada do poeta/artista a um mundo pesaroso.

Por meio do léxico melancólico e da reflexão que o próprio Apollinaire faz sobre sua condição "maldita", coloca-se fora dos padrões da civilização burguesa, pois, ao invés de trabalhar e ser "útil" para tal sociedade, que assim o espera, ocupa-se da literatura, dos sonhos e dos versos.

Por fim, os dois poemas finalizam com imagens que reforçam a condição de infortúnio do eu lírico, pois em "Signe", as pombas que se preparam para dar o último vôo não são pássaros que representam a paz, como assim o era esperado, mas aves de mau agouro cuja função é trazer o "mau destino", a morte: "Les colombes ce soir prennent leur dernier vol" (V.8). Também “Oceano" apresenta em seu dístico final a voz que denuncia o pesar sem consolo do eu lírico mal-amado, a sua má sina que cresce com o passar dos anos, a sua morte vindoura, quiçá da "companheira de todas as horas" como o próprio Bandeira nomeou: “- Voz de oceano que não vejo", "Da praia do meu desejo...”. 


\section{CONSIDERAÇÕES FINAIS}




\section{Considerações Finais}

Considerando o estudo realizado e os resultados de tal proposta de pesquisa, chegamos ao objetivo final deste trabalho que, desde a graduação, vem sendo desenvolvido: a confirmação de um eu lírico mal-amado na poética bandeiriana e apollinairiana. Esse sujeito poético sofre a ausência das coisas e sentimentos findos como resposta a um tempo não-reconciliado, proveniente de uma leitura deleuzeana do círculo eternamente descentrado, cujos vários subtemas aqui desenvolvidos corroboram a problemática pesarosa em questão.

Ademais, o estudo temático-comparativo das obras A cinza das horas e Alcools visou lograr um maior conhecimento da poética bandeiriana e apollinairiana, tanto no que concerne à fase parnasiano-simbolista, com traços anunciadores de tendências renovadoras da linguagem e da literatura, quanto às transformações pelas quais passaram até chegar, Bandeira ao Modernismo e Apollinaire às Vanguardas Francesas.

A análise dos subtemas que sustentam a condição do eu lírico mal-amado, seja na figura melancólica desse ser, seja nos cenários sombrios e crepusculares em que está inserido, reforça a nossa tese de que esse vive a dor da ausência, a eterna busca pelos sentimentos findos e pelo passado que esvaeceu com o decurso do tempo, permanecendo apenas o pesar pelo tempo não-reconciliado. 


\section{Referências Bibliográficas}

ABDALA JUNIOR, Benjamin (2004). Margens da cultura: mestiçagem, hibridismo \& outras misturas. São Paulo: Boimtempo.

ADÉMA, Marcel \& DÉCAUDIN, Michel (1956). Apollinaire: Oeuvres Poétiques. France: Gallimard.

ADÉMAR, Marcel (1952). Guillaume Apollinaire le mal-aimé. Paris: Librairie Plon.

AEGERTER, Emmanuel \& LABRACHERIE, Pierre (1945). Au Temps de Guillaume Apollinaire. Paris: René Julliard.

AMORIN, Silvana V. da Silva. Guillaume Apollinaire: fábula e lírica. São Paulo: Ed. da UNESP.

APOLLINAIRE, Guillaume (1996). Alcools. Paris : Gallimard.

ARRIGUCCI JR. Davi (1990). Humildade, paixão e morte. A poesia de Manuel Bandeira. São Paulo: Companhia das Letras.

(1983). "O Humilde Cotidiano de Manuel Bandeira". In: SCHWARZ, Roberto (org.). Os pobres na Literatura Brasileira. São Paulo: Brasiliense, pp. 106122.

BACIU, Stefan (1966). Manuel Bandeira de Corpo Inteiro. Rio de Janeiro: José Olympio.

BANDEIRA, Manuel (1982). Estrela da vida inteira. 9 ed. Rio de Janeiro, José Olympio (Col. "Sagaran", 85).

BANDEIRA, Manuel (1997). Seleta de Prosa. Rio de Janeiro: Nova Fronteira.

BIEDERMANN, Hans (1993). Dicionário de Símbolo. São Paulo: Melhoramentos.

BRAYNER, Sonia (1980). Manuel Bandeira. Rio de Janeiro: Civilização Brasileira; Brasília: INL. 
BRUNEL, Pierre \& CHEVREL, Yves (2004). Compêndio de Literatura Comparada. Lisboa: Fundação Calouste Gulbenkin.

BURGOS, Jean (1998). Études et recherches sur l'imaginaire. Paris : Lettres Modernes.

CAMPOS, Haroldo de. "Bandeira, o Desconstelizador". In: (1976). Metalinguagem. 3 ed. São Paulo: Cultrix, p. 99-105.

CANDIDO, Antonio. "Uma Aldeia Falsa". In: (1985). Na Sala de Aula: Caderno de Análise Literária. São Paulo: Ática.

CANDIDO, Antonio (s.d.). O estudo analítico do poema. São Paulo, USP/FFLCH.

CARA, Salete de Almeida (1981). Manuel Bandeira/seleção de textos, notas, estudos biográfico, histórico e crítico e exercícios. São Paulo: Abril-Educação.

CARVALHAL, Tânia Franco (2003). O próprio e o alheio. São Leopoldo: Usinos.

CHEVALIER, Jean \& GREERBRANT, Alain (1992). Dicionário de Símbolos. Rio de Janeiro : José Olympio.

COELHO, Joaquim-Francisco (1938). Manuel Bandeira pré-modernista. Prefácio de Gilberto Freyre. Rio de janeiro: J. Olympio; Brasília: INL,1982.

COELHO, Joaquim-Francisco (1981). Biopoética de Manuel Bandeira. Recife: Massangana.

CUNHA, Betina R. R. Da. A poética na obra de Élaurd e Bandeira. São Paulo: Annablume, 2000.

DÉCAUDIN, Michel. (1993). Alcools de Guillaume Apollinaire. Paris: Gallimard.

DELEUZE, Gilles (1968). Différence et répétition. Paris : Presses Universitaires de France.

GARBUGLIO, José Carlos (1998). Roteiro de Leitura: Poesia de Manuel Bandeira. São Paulo: Ática.

GUILLÉN, Claudio (1985). Entre lo uno y lo diverso. Introducción a la literatura comparada. Barcelona : Editorial Crítica.

GUIMARÃES, Júlio Castañon (1984). Manuel Bandeira. São Paulo: Brasiliense. 
HOLANDA, Sérgio Buarque de \& BARBOSA, Francisco de Assis (1958). Manuel Bandeira Poesia e Prosa. Vol.1, Rio de Janeiro: José Aguilar.

HUIZINGA, Johan (1978). “A visão da morte”. In: O declínio da Idade Média. (trad. de Augusto Abelaira). São Paulo: Verbo/USP. p. 129-139.

JUNQUEIRA, Ivan (2003). Testamento de Pasárgada: antologia poética. Rio de Janeiro: Nova Fronteira.

LECHERBONNIER, Bernard (1983). Apollinaire : Alcools. Paris : Éditions Fernand Nathan.

LEFÈVRE, Roger (1920). Classiques Larousse alcools choix de poèmes Apollinaire. Paris: Librairie Larousse.

LIMA, Alceu Amoroso (1993). Poesia/ Manuel Bandeira. 2.ed, Rio de Janeiro: Agir.

LOPEZ, Telê Porto Ancona (1987). Manuel Bandeira: Verso e Reverso. São Paulo: T.A Queiroz, Editor, LTDA.

MARTINS, Carlos Alberto Shimote. Manuel Bandeira: Um lírico no Alvorecer do século XIX. (Dissertação de Mestrado). São Paulo: Universidade de São Paulo, 1994.

MELLO e SOUZA, Gilda de \& CANDIDO, Antonio. "Introdução". In: BANDEIRA, Manuel (1986). Estrela da vida inteira: poesias reunidas. 11 ed. Rio de Janeiro: José Olympio, p. XIII-XXXIII.

MIRADOR Internacional (1975). São Paulo/Rio de Janeiro.

MOISÈS, Leyla Perrone (1990). Flores da escrivaninha. São Paulo: Companhia das Letras.

MONTEIRO, Adolfo Casais (1958). Manuel Bandeira.Rio de Janeiro: Departamento de Imprensa Nacional/Ministério de Ed.e Cultura/Serviço de Documentação.

MORAES, Emanuel de (1962). Manuel Bandeira Análise e Interpretação Literária. Rio de Janeiro: José Olympio.

MORAES, Emanuel de (1986). Seleta em presa de verso.4.ed, Rio de Janeiro: José Olympio.

MORHANGE-BÉGUÉ , Claude \& LARTIGUE, Pierre (1993). Profil Littérature Alcools Apollinaire. Paris: Hatier. 
NITRINI, Sandra (2000). Literatura Comparada: história, teoria e crítica. São Paulo: Editora Universidade de São Paulo.

PASSALACQUA, Elisabete Maria (2003). Bandeira, Apollinaire e a Modernidade (Dissertação de Mestrado). Araraquara: Universidade Estadual Paulista.

PELBART, Peter Pál (1996). O tempo não-reconciliado (Tese de Doutorado). São Paulo: Universidade de São Paulo.

POIRION, Daniel (1965). "Préface". In: Villon: oeuvres poétiques. Paris: Garnier-Flammarion.

PONTIERO, Giovanni (1986). Manuel Bandeira: visão geral de sua obra. Rio de Janeiro: José Olympio.

RODRIGUES FILHO, José Maria. O Barão, de Branquinho da Fonseca: De sua Fortuna Crítica a um Estudo Temático-Comparativo. (Tese de Doutorado). São Paulo: Universidade de São Paulo.

ROSENBAUM, Yudith (1993). Manuel Bandeira: Uma Poesia da Ausência .São Paulo: Editora da Universidade de São Paulo; Rio de Janeiro: Imago.

ROUVEYRE, André (1945).Guillaume Apollinaire. Paris: Gallimard.

ROUVEYRE, André (1955). Amour et poésie d'Apollinaire. France: Seuil.

SANT'ANNA, Affonso Romano de. (1984). O Canibalismo Amoroso. Rio de Janeioro : Editora Rocco.

SIMON, P. H (1959). Histoire de la Littérature Française Au XX Siècle. Paris: Armand Colin.

SITE : www.meiodoceu.com (dicionário de símbolo de Claudia Araújo)

TROUSSON, Raymond (1965). Un problème de littérature comparée. Paris: Lettres Modernes.

UNIVERSALIS France (1990). Éditeur à Paris.

VAILLANT, Alain (1992). La Poésie. Paris: Éditions Nathan.

VIALLANEIX, Paul. Apollinaire et les saisons de l'amour. Critique, tome XXV, $\mathrm{n}^{\circ}$ 260, janvier 1969, p. 41-53. 
VILLAÇA, Alcides. "O Resgate Íntimo de Bandeira”. In: LOPEZ, Telê Porto Ancona (org.) (1987). Manuel Bandeira: Verso e Reverso. São Paulo: T. A. Queiroz.

VITUREIRA, S.Cipriano (1952). Manuel Bandeira Cecília Meireles Carlos Drummond de Andrade Tres Edades En La Poesia Brasileña Actual. Brasil-Uruguay: Ediciones A. C.E.B.V. Montevideo.

WHITROW, G. J. (1993). O Tempo na História. Rio de Janeiro: Jorge Zahar. 